Portland State University

PDXScholar

$1-1-1978$

Recent and contemporary foraging practices of the Harney Valley Paiute

Marilyn Dunlap Couture

Portland State University

Follow this and additional works at: https://pdxscholar.library.pdx.edu/open_access_etds

Part of the Indigenous Studies Commons, and the Social and Cultural Anthropology Commons Let us know how access to this document benefits you.

Recommended Citation

Couture, Marilyn Dunlap, "Recent and contemporary foraging practices of the Harney Valley Paiute" (1978). Dissertations and Theses. Paper 480.

https://doi.org/10.15760/etd.480

This Thesis is brought to you for free and open access. It has been accepted for inclusion in Dissertations and Theses by an authorized administrator of PDXScholar. Please contact us if we can make this document more accessible: pdxscholar@pdx.edu. 


\title{
RECENT AND CONTEMPORARY FORAGING PRACTICES OF THE HARNEY VALLEY PAIUTTE
}

\author{
by \\ MARILYN DUNLAP COUTURE
}
A thesis submitted in partial fulfiliment of the requirements for the degree of

\author{
MASTER OF ARTS \\ in \\ ANTHROPOLOGY
}

Portland State University

(C) Marilyn Dunlap Couture 1978 
TO THE OFFICE OF GRADUATE STUDIES AND RESEARCH:

The members of the Committee approve the thesis of Marityn Dunlap Couture presented 27 January 1978.

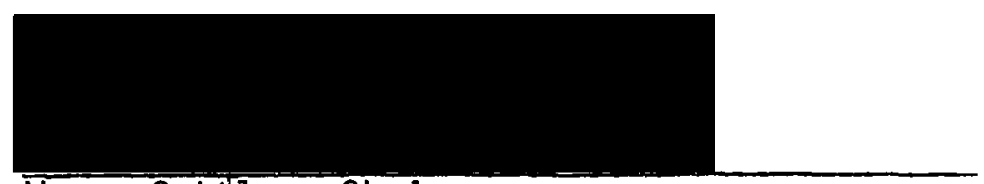

Wayne Suttles, Chairman

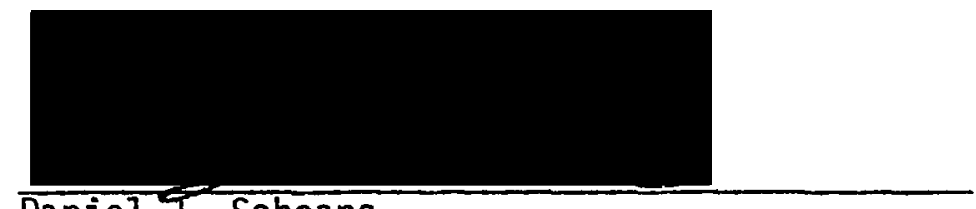

DanieT J. Scheans

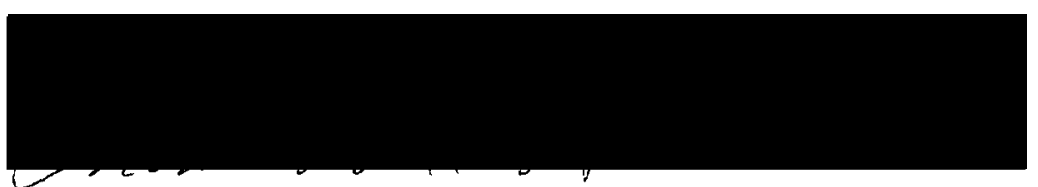

Thomas M. Newman

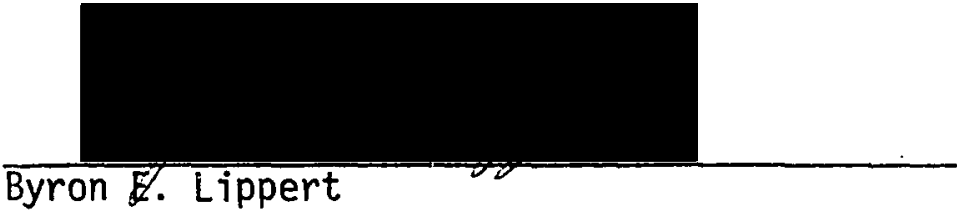

Daniel j. Scheans, Heجd Anthropology Department

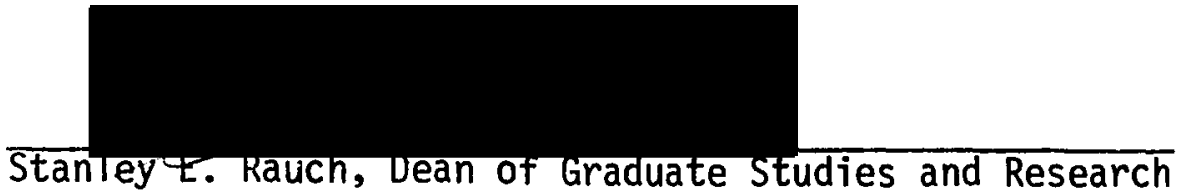


AN ABSTRACT OF THE THESIS OF Marilyn Dunlap Couture for the Master of Arts in Anthropology presented 27 January 1978, Portland State University, Portland, Oregon.

Title: Recent and Contemporary Foraging Practices of the Harney Valley Paiute.

Native plants still play an important part in the lives of some American Indians. This thesis describes recent foraging practices which persist among the Harney Valley Paiute, a group of Northern Paiute Indians which formerly occupied a 11 of Harney Valley in southeastern Oregon. The field research was conducted from 1973 to 1978 . The traditional seasonal harvest round is described as well as the identification, habitat, distribution, and seasonality of forty-one plant species. Native plant use, subsistence and the role of plants, foraging techniques, implements, processing, preservation, intertribal relations, trade patterns, and tribal movements are also presented. 


\section{ACKNOWLEDGMENT}

To Clay for his enduring support and encouragement and to Cathy, Jerry and Joe who shared in this project and were subjected to wild food concoctions, sometimes over their protestations.

I am indebted to my friend Tom Newman who fired my interest in the Harney Valley Paiute, and to my other university research advisers, Drs. Wayne Suttles, Daniel Scheans, David French, Catherine Fowler, C. Melvin Aikens and B. E. Lippert for their encouragement and criticism.

A specia? thanks to Mary Ricks, confidant and assistant, who "grazed" with me across the high desert country; and to Bob Bague, Ruth McGilvra Bright, Bill Cannon, Jarah Davies, John Fagan, Marilyn Peterson, and Roger liggin, for their unending emotional support.

Thanks are extended to Jessie Wi?liams, Phyllis McGraw, Patty Barnhart, Mary and Dean Dozark for their assistance. The financial support extended by the Melville and Elizabeth Jacobs Research Fund is gratefully acknowledged.

My sincere appreciation to Marian, Nepa, Emma, Justine, Agnes, Rena, Ramona, Earl, Alfred, Alma, Maude, Bernice; Esther, Virginia, Theresa, Violet, Julie and Sally; were it not for these Native Americans and their forebears, this could never nave been written. This thesis is dedicated to them. 
ACKNOWLEDGMENTS $\ldots \ldots \ldots \ldots \ldots \ldots \ldots \ldots \ldots \ldots \ldots \ldots \ldots \ldots \ldots \ldots \ldots \ldots \ldots$

LIST OF FIGURES $\ldots \ldots \ldots \ldots \ldots \ldots \ldots \ldots \ldots \ldots \ldots \ldots \ldots \ldots \ldots \ldots \ldots \ldots \ldots \ldots$

CHAPTER

I INTRODUCTION.................................. 1

Sources of Information.................... 5

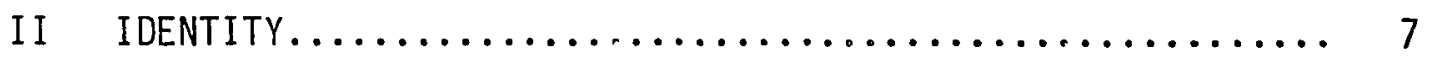

Name, Area Occupied, Language.............. 7

Territory........................... 8

History.............................. 10

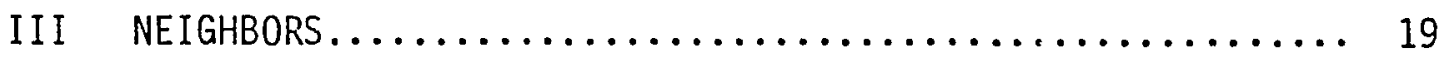

Tribal Distribution...................... 19

Inter-Tribal Relations, Trading and Tribal

Movements.......................... 20

White Contact and Early Epidemics............. 23

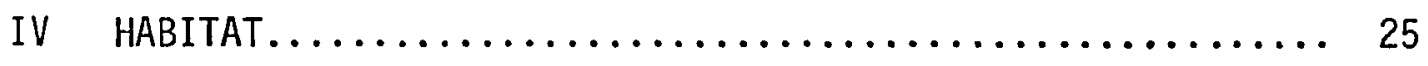

Division of Regions and Associated Resources...... 25

Seasonal Round.......................... 27

Place Names............................ 31

$\checkmark$ SUBSISTENCE AND THE ROLE OF PLANTS............... 33

Hunting and Fishing........................ 33

Importance of Plants..................... 35 
CHAPTER

Division of Labor........................ 37

VI PLANTS USED .......................... 39

VII AN EXPLORATION IN TAXONOMIC PRINCIPLES.............. 103

VIII COMPARISON WITH SURPRISE VALLEY PAIUTE AND OWENS VALLEY

PAIUTE........................... 109

Surprise Valley Paiute......................... 109

Owens Valley Paiute........................ 110

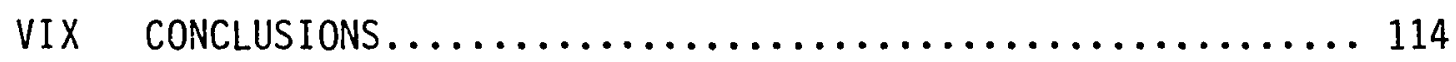

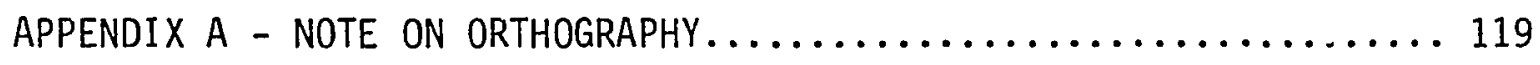

APPENDIX B - DICTIONARY OF PLANT NAMES ................ 120

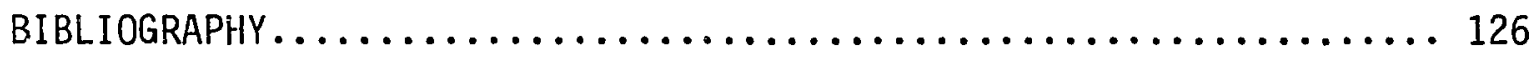




\section{LIST OF FIGURES}

FIGURE

PAGE

1 Paiute rootdigger, child and author's daughter

collecting wild foods, May, 1975................... 3

2 Map of Harney Valley Paiute territory................ 9

3 Physiographic and geological provinces of Oregon and Washington (Ba 7 dwin 1964, Fenneman 1931, and Esterbrook and Rahn 1.970 in Franki in and Dyrness

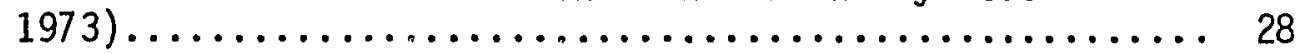

4 Aca (Descurainia sophia) tansy mustard.............. 41

5 Cana-cuka (Lomatium canbyi) biscuit root............. 44

6 Cuka (Lomatium cous) biscuit root................ 46

$7 \quad$ Cuka (Lomatium cous) biscuit root in bloom and digging stick handle................................ 48

8 Paiute root digger rinsing roots in Pine Creek.......... 49

9 Kanicy (Lewisia rediviva) bitterroot................ 51

10 Kanicy (Lewisia rediviva) bitterroot at the bud stage and peeled roots......................... 53

11 Peeled bitterroot spread in the sun and wind to dry...... 54

12. Koogi (Zygadenus venenosus) death camas growing amidst a field of blue camas (Comassia quamash)............. 56

13 Kyyga (Azzizm sp.) wild onion..................... 59

14 Paazigo (Ccmassia qucmash) blue camas................ 62

15 Paazigo (Comassia quicmash) blue camas growing in meadows near Harney.......................... 64

16 Peeled willows form the fraine and warp of a cradleboard................................... 75 
17 Tokabonoma (Vaccinium membranaceum) blue huckleberry...... 77

18 Tooisabui/nokopisa (Prunus virginiana) chokecherry....... 79

19 Tooisabui (Prunus virginiana) chokecherry............. 80

20 Digging stick............................ 83

21 Tyba (Pinus mcnophyzza) pinyon pine............. 86

22 Waada (Suaeda sp.) seepweed.................... 8 s

23 Wauda (Suaeda intermedia) seepweed, "tiny black seeds".... 91

24 Field of waada growing near Malheur Lake............. 91

25 Yapa/yampa/payapa/suiyapa (Perideridia bolanderi) wild

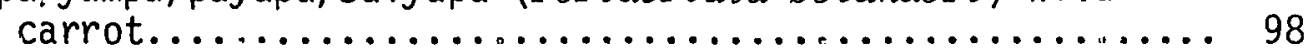

26 Pamahayapa (Perideridia oregana Wats.) wild carrot........ 100 
CHAPTER I

INTRODUCTION

Ethnobotany has been described by Claude Levi-Strauss (1966) as one of the cultural "niches" in which traditional lore finds refuge and which is strongly resistant to the impact of civilization. Through independent research I discovered that a few older members of the Burns Paiute Indian Colony are still engaged in gathering wild plants for food, medicinal purposes and the manufacturing of usefur items. The purpose of this thesis is to report the recent and contemporary foraging practices of these people based upon field research conducted from 1974 through 1978. A description of these activities focuses upon and includes the following:

1. Identification of piant species and native terms;

2. Habitat, description and distribution of plant species;

3. Native use, whether for food, medicinal or material culture;

4. Collecting techniques and implements used;

5. Processing, including methods of handling;

6. Preservation, including methods of drying and storage;

7. Traditional seasonality of foraging practices vs. residuat? practices of today.

Insofar as possible I compared these practices cross-culturally with those of the Surprise Valley Paiute (Isabel Kelly 1932) and the Owens Valley Paiute (Julian Steward 1933). I also explored and described the 
role of plants, trade patterns, the taxonomic principles underlying some native terms, as well as the kinds of conditions through which traditional lore survives.

My first Archeological Field School experience under the direction of Dr. Thomas M. Newman at the Malheur Environmental Field Station, Burns, Oregon, 1973, caused me to return the following summer to learn what I could of the history of Harney County, with my search ultimately bringing me in contact with the Burns Indian Community. Through a mutual friend and local historian, Jessie Williams, I met two Paiute Indian women who generously offered to share with me whatever information they knew. On their own initiative they invited me to participate in their foraging activities, and to "Come back in the spring and dig roots with us, so you can see for yourself." Undoubtedly, their acceptance of me was a consequence of their implicit trust in Jessie, whose family had always maintained a unique and good relationship with the local Indian population.

I have chosen to protect the identity of individuals who voluntarily associated with me throughout this study. Unless otherwise stated, the information contained within was obtained largely through observation, oral histories, and personal contact with older members of the Burns Paiute Community, especialiy from those who could remember the days when wild plants were used extensively.

The present study was begun in 1974 and undertaken in May, 1975, when I returned to Burns with my daughter Cathy in order to accompany the Indian women into traditional habitats on their annual spring sojourn to gather wild plants for food (Figure 1). I discovered that of 


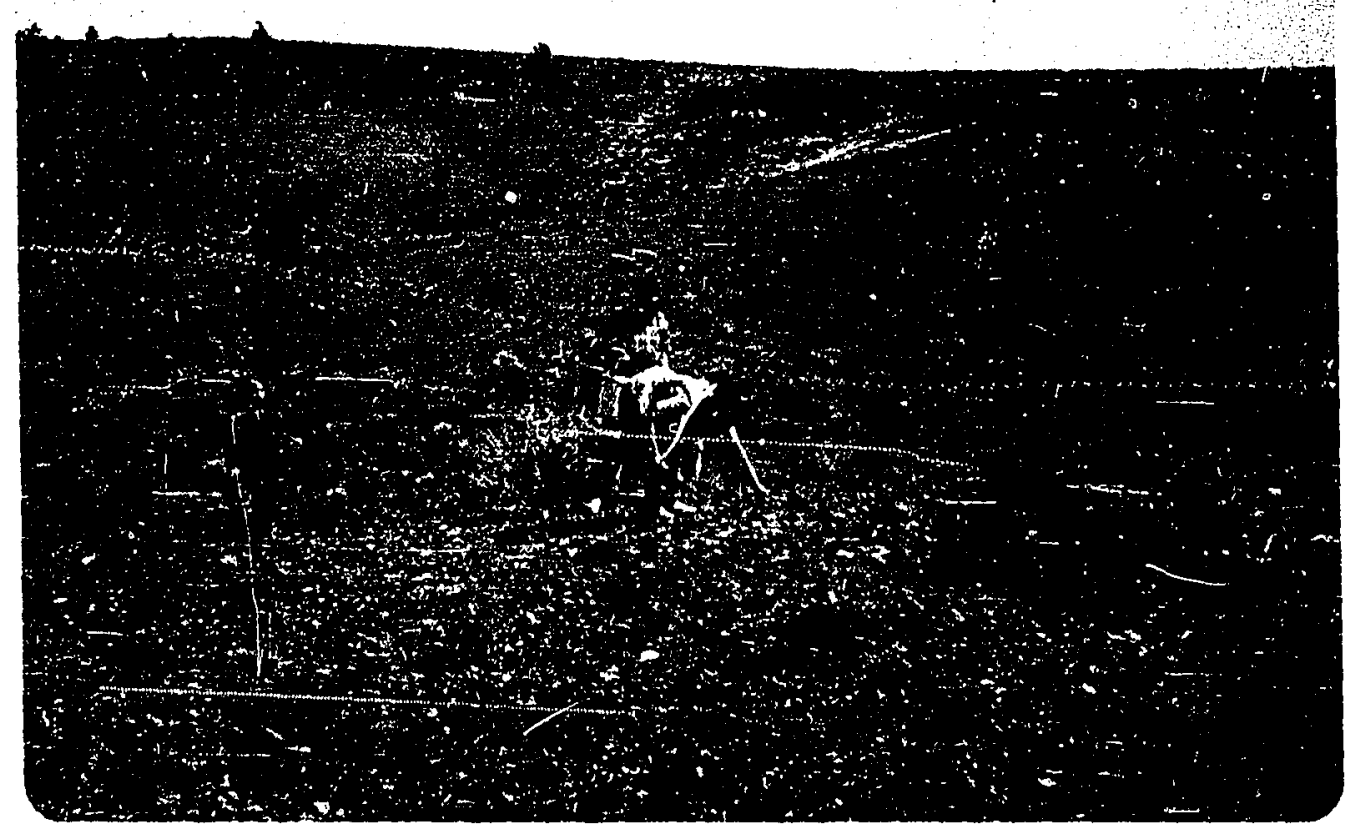

Figure 1. Paiute rootdigger, child and author's daughter collecting wild foods, May, 1975. 
the one hundred fifty native resident members, there are probably less than ten older femaies who persist in foraging activities to some degree at the present time. Furthermore, only these few older women are well versed in the detailed names, usages and roles of wild plants which relate to their culture. Therefore, all available information must be recorded soon or it will be lost forever.

I returned to the area in September, 1975, to observe and record what I could about seed collecting and chokecherry gathering, and again in November, 1975, to observe the fall activities in preparation for winter. It was on the latter trip that I learned that several women still collect willow on the banks of the Silvies River for use in manufacturing cradle boards.

A research grant awarded by the Whatcom Museum Foundation from the Melville and Elizabeth Jacobs Research Fund enabled me to return to the field in May, 1976, to observe further and record the spring root digging; to be on hand again in July, 1976, to collect wild currants; to accompany two Indian women on a campout in August, 1976, to pick huckleberries; and to return in May, August and September, 1977, to record their gathering practices by Super $8 \mathrm{film}$; and, again in May and September, 1978. I intend to pursue this study further and continue learning from these people who have much to share in spite of the losses they have suffered.

This research is presented as a contribution to the ethnobotany and the ethnography of the Harney Valley Paiute. There has been a significant loss of available ethnobotanical information as a direct result of native acculturation since the mid-nineteenth century. It 
is hoped that this paper will contribute to a permanent record of the nallies, uses and roles of plants in both recent and contemporary Northern Paiute sulture. This information shoula prove useful and of interest to the younger generation of native Americans who are growing up in the area with little knowledge of traditionai lore. Furthermore, I trust that this research will contribute to Northern Great Basin prehistory and also to the preservation and protection of the nonrenewable cuTtural resources in the area.

Sources of Information

To my knowledge, the only notable prior works done which relate directly to the Harney Valley Paiute are Paiute Sorcery (Whiting 1950) and Culture Element Distributions: XIV Northern Paiute (Stewart 1941). Whiting's (1950) work was essentially a study in mechanisms of social control. As part of her ethnography she did an overview of Paiute subsistence activities as they related to her interest. Stewart's (1941) account was done while laboring under conditions unfavorable for a detailed ethnographic study. By his own admission (Stewart 1941:365) his interpreters were not veiry good; in addition, his informants were for the most part either older men suffering from blindness who lacked information concerning much of the culture or people who were uncooperative.

In addition, I consulted primarily with Ethnography of the Surprise Valley Paiute (Kelly 1932); Ethnography of the Owens Valley Paiute (Steward 1933); Basin-Plateau Aboriginal Social Political Groups (Steward 1938): Life Amona the Paiutes; Their Wrongs and Claims (Hopkins 1883); Survival Arts of the Primitive Paiutes (Wheat 1967); Some 
Northern Paiute Native Categories (Fowler and Leland 1967); The Current Status of Anthropological Research in the Great Bas in (d'Azevedo, Davis, Fowler, and Suttles 1966); Flora of the Pacific Northwest (Hitchcock and Cronquist 1973); and Mammals and Life Zones of Oregon (Bailey 1936). An unpublished manuscript was consulted, Field Notes on the Burns Northern Paiute Indians (Marsden 190 ) courtesy of Dr. Catherine Fowler. Also, for the nutrient composition of native American foods, I relied upon the results of a study conducted in 1972 jointly between Oregon State University Extension Service, the Department of Home Economics Research of the Oregon Agricultural Experiment Station and the Confederated Tribes at Warm Springs Indian Reservation. ${ }^{1}$ Drs. David French, Catherine Fowler and C. Melvin Aikens were consulted and offered support and advice through personal communication. A complete list of resources consulted is listed in the Bibliography.

${ }^{1}$ While the Burns Indians also participated in the project, no credit was given on their behalf (Teresa Hogue, County Agent, O.S.U. Extension Service). 
CHAPTER II

\section{IDENTITY}

Name, Area Occupied, Language

The Burns Paiute Indian Colony, Burns, Oregon, is composed of people who are descendants of a Northern Paiute population which formerly occupied an area in Southeastern Oregon which centered on Harney Valley. This population was commonly referred to as waadadikady (waada eaters) by other Northern Paiute groups in the area, as they congregated near the shores of MaTheur Lake annually to harvest the tiny black seed called Waada. I have chosen to call this populatin Harney Valley Paiute in accordance with the practice of naming a grcup for its associated territory. ${ }^{1}$

The Harney Valley Paiute speak Northern Paiute which is one of three languages of the Numic family of Uto-Aztekan stock. The family has been divided into three sub-groups as follows: Mono-Paviotso ${ }^{2}$ (Mono-Bannock), Shoshone-Comanche, and Ute ${ }^{3}$-Chemehuevi (Wick Miller 1964; Sydney Lamb 1958; Kroebeir 1907).

As this report includes a comparison of the foraging practices of

1 Because the nature of alleged territorial groups has been under examination and disputed for years, I will describe the problem later in Chapter III, Triba? Distribution.

${ }^{2}$ Also known as Northern Paiute.

${ }^{3}$ Also known as Southern Paiute. 
the Harney Valley Paiute with both the Surprise Valley Paiute and the Owens Valley Paiute, it should be noted that all three groups share the Tanguage sub-group of Mono-Paviotso. However, this branch consists of two languages. One, the Mono, occupies the southern extremity of the Great Basin, i.e., Owens Valley. The other, Northern Paiute or Paviotso, occupies a much larger area to the north and includes northeastern California, southeastern Oregon, southeastern Idaho and parts of Nevada ranging from Pyramid Lake to Mono Lake Basin, with all of the people of the latter speaking variant dialects of a single language (Làmb 1958).

\section{Territory}

The Harney Valley Paiute formerly occupied all of Harney Valley, centering around Malheur Lake and extending north to the headwaters of the Silvies River, west to Wagontire, southwest to Beatty Butte, south to and including Catlow Valley, southeast to Alvord Lake, and northeast to Drewsey along the Malheur River, an area of approximately $\varsigma, 000$ square miles in southeastern Oregon (Figure 2).

To understand Paiute Indian culture, one must comprehend the Indian concept of being attached to a commonly held piece of ground without the concept of private ownership to the exclusion of others. Although these territorial boundaries are not definite, there was a tendency to frequent the same hunting and gathering grounds from year to year, and they kept pretty much to these marginal 1 imits in their seasonal migrations. 


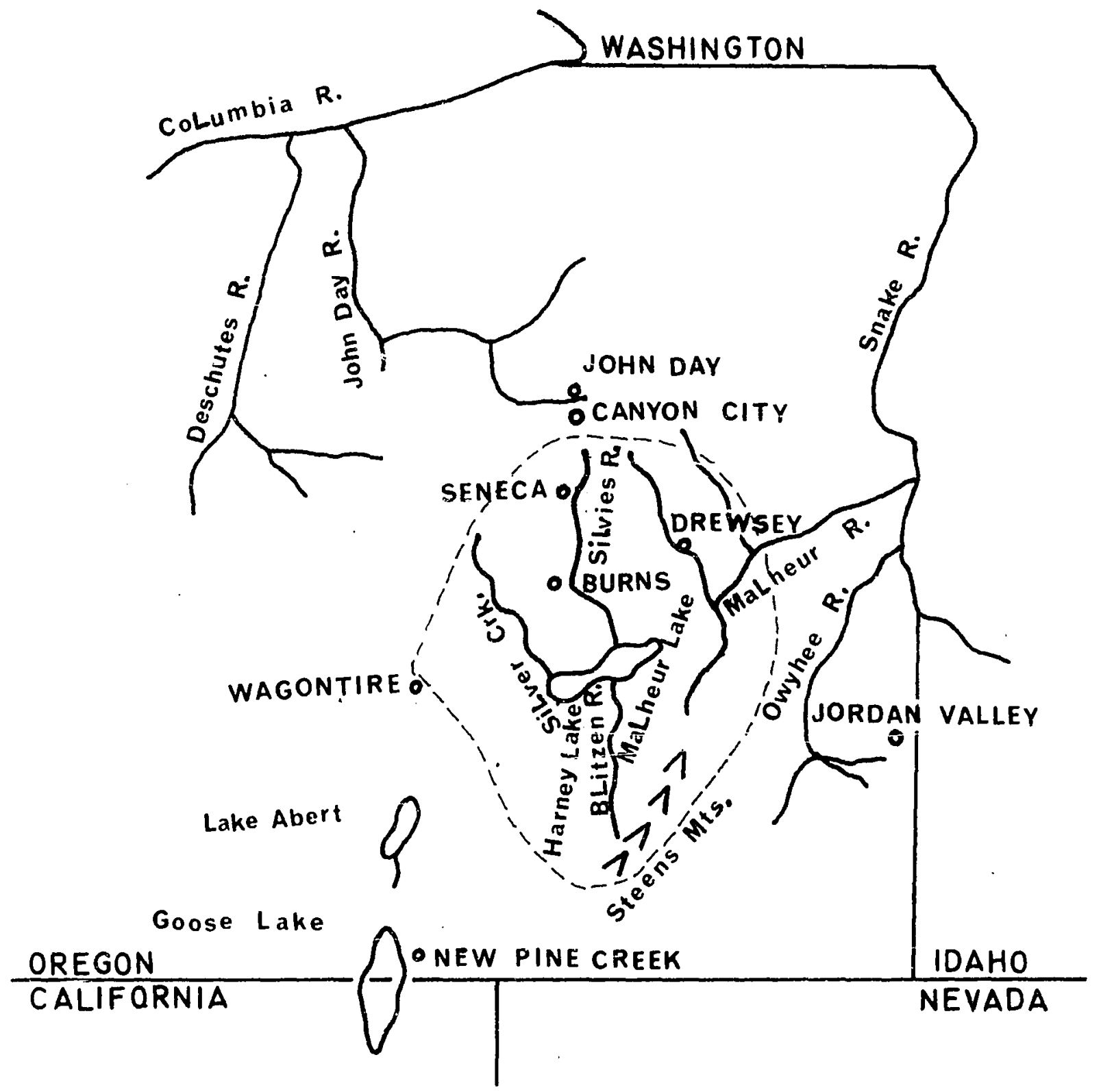

Figure 2. Map of Harney Valley Paiute Terinitory. 
History

This summary of the history of the Harney Valley Paiute is based upon ethnohistorical sources, accounts of early travelers and explorers, military records, Indian Claims cases, and oral histories obtained from native inhabitants of the Burns Paiute Indian Colony. The evidence revealed that these people travelled in sma 11 peaceful bands, that they had horses as early as $1828^{4}$, and that they were almost completely without firearms before 1850. Called waadadikady by other groups, they migrated extensively and shared areas where there was good fishing and hunting, and foraged for roots, berries and seeds where they were plentiful. While occupying an area which was virtually untouched and unsettled by Western civilization until late 19th century, they lived mostly at peace with neighboring groups of people.

For early historic accounts the reports of Peter Skene Ogden (Strong 1969) and John Charles Fremont (1843) were consulted. One remarkable Paiute Indian woman, Sarah Winnemucca Hopkins (1883), also contributed significantiy to the early history. While the Lewis and Clark Expedition of 1804-1806 merely skirted this area, Captain Merriwether Lewis (Wilson 1934) recorded a peaceful encounter with an Indian village on the Snake River in June 1806, at which time goods were traded.

ilowever, the early encounters were not always "peaceful" as recorded by Ogden (Strong 1969) in June, 1827, as follows:

\footnotetext{
${ }^{4}$ Captain Louje autobiography in unpublished M.S. of A. L. Kroeber (n.d.).
} 
The first experience the party had with the Indians was shortly after entering the Basin north of Burns, Oregon, where three Indians stole seven horses. Horse stealing was considered a game and not a crime by the Indians buit not so by the two trappers who pursued and overtook them. The Indians handed back the horses 'at the same time smiling' - they had lost the game but were good losers.

(Strong 1969:18)

Ogden (Binns 1967) further noted that the Indians had gathered in this valley to winter, that his group called all of them "Snakes", and he referred to the numbers present, as follows: "We cannot go ten yards without finding them. No Indian Nation so numerous as these in all North America" (Binns 1967:192). Fremont's (1843) presumably peacefu1 and scientific expedition to the Oregon territory in 1843 was conducted with the aid of substantial armament though the War Department expressed disapprova1. Fremont's impressions of the "Root Diggers" west of the Rocky Mountains are recorded, as follows:

They are miserably poor, armed only with bows and arrows or clubs. ...Roots, seeds and grass, every vegetable that affords any nourishment and every living animal thing, insect or worm, they eat. Nearly approaching to the lower animal creation, their sole employment is to obtain food; and they are constantly occupied in a struggle to support existence.

(Fremont 1843:487)

For another impression of early contact, Sarah Winnemucca Hopkins (1883:10-11) recalled that her father, Chief of the Carson River Paiutes about 1845, befriended the first whites, caring for them and giving them food when they failed to get over the Sierra Nevada Mountains in the fa11. She stressed that her people did not seek to kill them, nor did they steal their horses, nor did they ask for payment for the food. However, the following spring the Indians were forced to flee into the mountains for fear of the whites who reportedly were killing anyone in 
their way. With the initial white contact came disease, to which the Indians had no resistance. ${ }^{5}$

The migration of white settlers to Oregon (C1ine 1963:91) began in 1841 and within five years there were 5000 settlers in Oregon Territory. Added to this was the discovery of gold in California in 1848 , causing thousands of immigrants to move westward. With definite changes in the lives of native Americans, i.e., horses, guns, liquor and disease, the seeds of discontent and war began to germinate.

With white encroachment onto Harney Valley Paiute territory, the military established Camp wight on 0ctober 3, 1865, on the Sitvies River. ${ }^{6}$ The camp was not substantially fortified; the soldiers pr..tected themselves by building up sod walls with roofs of poles cover ad with earth. 7

Camp Wright was disbanded two years later and replaced by Camp Settler August 16, 1867, with the name changed to Camp Harney September

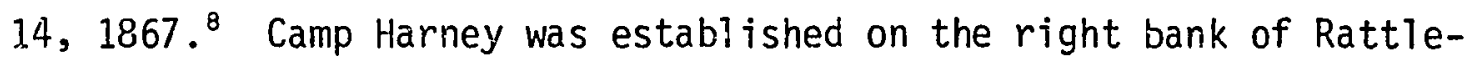
snake Creek two miles above its sink in a deep canyon, surrounded by hil1s. The Post, Wood and Hay Reservations of Camp Harney were estab1 ished by Executive Order, December 5, 1872, and made subject to Executive Order of September 12, 1872, establishing the Malheur Indian Reservation.

${ }^{5}$ Fuller treatment is given to this aspect in Chapter III, White Contact and Early Epidemics.

${ }^{6}$ Burns Times Herald, January $31,1963$.

${ }^{7}$ Ibid.

${ }^{8}$ Harney County Historical Society. 
Oral histories obtained from native inhabitants demonstrate and confirm the strained early Indian-White relationship. They recalled to me a soldier raid that occurred in the Harney Valley in the latter half of the 19th Century. Indian scouts saw the soldiers from a distance and gave a warning which permitted the camp to escape. Blind Jim, a member of the group camped, was saved by his friends who hid him under a bush with instructions for him to remain there until they returned for him. Frequently it was necessary to hide old people and children when they were threatened by soldiers or white men. On another occasion a group of women who were out digging roots away from camp saw in the distance a reflection of the sun, which they interpreted as a soldier's binoculars. Believing the soldiers would rope and tie them up, they headed for high rocky ground and escaped, knowing that the horseshoes of the soldiers' ponies would slip on the rocks, holding the soldiers back. On an additional occasion one woman's mother escaped from soldiers when they chased her. Her escape was attributed to her being slim and a fast runner, and the fact that the soldiers were out of bullets. Similar events were repeated over and over again and are recorded by oral tradition.

With whites continuing to encroach on Indian lands and as an inducement for roving and straggling bands in Southeastern Oregon to settle there, the Malheur Indian Reservation was set apart by Executive Order on September $12,1872 .{ }^{9}$ The reserve contained approximately 1,778,560 acres or 2285 square miles in Harney and Malheur Counties,

\footnotetext{
${ }^{9}$ Harney County Historical Society.
} 
and was bounded by the Silvies River on the west, Strawberry Butte on the north, Castle Rock on the east, and Malheur Lake on the south. Many Indians settled there, and in 1876 according to Hopkins (1883:125) there were over 2000 recorded at the Malheur Agency.

Problems arose (Hopkins 1883:125) as a result of poor management on the reservation, $i . e$. , dishonest agents rented the reservation out to cattlemen and got a dollar a head for the cattle, without passing it on to the Indians. In addition, agents stole from the Indians, charged them exorbitant prices for rations, clothes and supplies, and "forgot" to pay them for the Tabor they performed. Added to this was the unsuccessfut attempt of the government to turn the Indians into farmers. With the outbreak of the Bannock War of 1878 , some Paiutes jointed with the hostiles and others fled to the protection of the Army. Oral history discloses that at the close of the war approximately 543 Paiutes were transported either to the Yakima Reservation or to Fort Vancouver, Washington. Reportedly, in January 1879, the long trek began as the men in shackles walked all the way, and women and childrell were transported in wagons. Here they lived with strangers from other tribes for as long as five years, with some eventually drifting back to the Harney Valley. On their return they lived in a wretched condition, without sufficient food, clothing or a place to live. During this period ranchers and stockmen moved in to occupy and use much of the Matheur Indian Reservation area. ${ }^{10}$ The greater part of the Reservation was restored to Public domain by Executive Orders of September 13, 1882 ,

\footnotetext{
I Burns Chamber of Commerce correspondence.
} 
May 21,1883 , and 1889, opening a large area to settlement. ${ }^{12}$

In exchange for their Reservation, Indians who returned to the Harney Valley were offered a 160 acre allotment by the government. Many walked back to claim their allotment; other's not trusting the ways of the white men refused theirs. In 1896 and 1897, pursuant to a Secretarial Order signed January 24, 1880, only 115 remnant members received allotments oi 160 acres each, out of a possible 600 Paiutes who had occupied the area only a few years before. ${ }^{13}$ Some tried to occupy their allotments for a time, but due to the lack of means with which to produce a liying, they soon turned to other means of existence. Otiters camped in the Sagehen Hills behind the town of Burns.

Jessie Williams, white pioneer descendant, reported to me that the indians came each summer and camped by Silver Creek around the turn of the century. Her father employed them to do the haying to fulfill his contract to Hanley, owiter of the Double 0 Ranch. Here the Indians lived in skin covered teepees as late as 1905 . Jessie recalled her mother cooking for the Indian men and feeding them under a covered shade made of Juniper poles, covered with grass and skins. The Indian women washed and scrubbed clothes for her mother. She :-acin? led that the Indian women and children kept to themselves while camped there. The women would walk for miles to collect the right kind of willow for baskets and then sit along the banks of Silver Creek weaving them.

The bare existence of these people coritinued into the early 1920s

\footnotetext{
${ }^{12}$ Harney County Historical Society.

${ }^{13}$ Burns Chamber of Commerie correspundence.
} 
and is recorded in an oral statement made to Pauline Braymen, as follows:

In those days the Indian had nothing; men had no jobs. Women made buckskin gloves and traded them for flour, sugar and coffee. They had to work hard and lived behind the town with no water. People carried water to their homes in buckets. 1923 was a hard winter with heavy snow. Most of the people had the flu, no wood and 7 ived in tents and teepees. ${ }^{14}$

To help meet their needs, in 1925 ten acres were given to them, provided they clear the land themselves. In addition, twenty houses, a school house, laundry and bath house were constructed. In 1928 the Indians attempted to integrate with the Burns public school. They were refused on the grounds that they had trachoma, tuberculosis and venereal disease.

In the 1930s and 1940s under a Subsistence Homestead and Rehabilitation program, land was purchased north of Burns, and the Indians were relocated to the present location. Under this program domestic water, homes, a community meeting ha 11, and an Indian day school were provided. Since 1946 the Indian children have been under the State Public School system. ${ }^{15}$

The Court of Claims in 1960 approved a judgment claim in favor of the MaTheur group of Snake or Paiute Indians for loss of lands. ${ }^{16}$ The Ma1heur Indian Reservation of $1,778,560$ acres was appraised at $\$ 567,000$ (about $32 \phi$ per acre). After reduction for attorneys' fees and expenses of $\$ 98,000$, plus increased interest earned, the amount of $\$ 519,827.49$

\footnotetext{
${ }^{14}$ Oral history recorded by Pauline Braymen, 1970 s.

15 Burns Chamber of Commerce correspondence.

1 G Burns Chamber of Conmerce correspondence.
} 
was appropriated by Congress and directed paid per capita to descendants of the original inhabitants of the Reservation. Applications were received until May, 1965. Some 254 Burns Paiute Indians shared with Snake and other Pajute in judgment in Docket No. 17 decided December 18, 1956, which amounted to a per capita payment in 1969 of \$743.20. Needless to say, the long wait and insignificance of this amount was a source of frustration and bitterness to these people. The Burns Paiute colony was formally recognized as an organized Indian band when its constitution and bylaws were approved by the Commission of Indian Affairs, June 13, 1968, urder authority of the Indian Reorganization Act (1933). By virtue of H. R. 6318, dated May, 1972, certain federally owned lands were ordered held by the United States in trust for the Purns Indian Colony which totaled 760 acres. ${ }^{17}$ As of March, 1970, the Colony was composed of 250 members with a resident population of 150 .

In 1976 under the Economic Development Act, the Burns Colony became eligible for a new social and economic project in the amount of $\$ 700,000$. It provided for the construction of a new Indian development to be located on higher ground on their existing land, including a community center as well as long range plans for a subdivision, and for the removal of the existing homes in the area by 1995 or later. This is the

${ }^{17}$ The 760 acres is composed of the following three tracts:

1. Subsistence Homestead Tract - 156.26 acres purchased under NIRA 1933;

2. Submarginal Tract - 1938 (used for grazing) from Department of interior - 605.67 acres;

3. Donated Tract - 10 acres (U.S. Department of Interior correspondence). 
first reservation to participate in the National Ficod Release Program, and wi11 offer some protection against the uninsured losses suffered by the tribe when they are faced with the annual threat of flooding due to melting snow and rain.

While the last twenty years of the 19th Century and the first thirty years of the 20th Century represent a sad story of unwise and unjust treatment of native Americans, the Burns Paiute Indians in recent times have had their lot improved along the lines of housing, education, job training, and public health. Some of the adult males are employed seascra?!y on ranches and in the lumbering industry around Seneca and Burns, and some of the adult females are employed as cleaning women by white women in Burns. However, a number are unemployable for many reasons such as age, physical disability and lack of sufficient education or training, and excess alcohol consumption continues to be a problem for many.

Through all their adversities, some older tribal members have kept their traditions alive. They return to the country on every opportunity to renew their relationship with the land, whether to gather wood in the forests, fish or hunt, or to gather wild plants for food and other uses. As one man said, "..his people had fought hard for this land; he could never leave it, for the earth was his mother and the wind his brother." 


\section{CHAPTER III}

\section{NEIGHBORS}

\section{Tribal Distribution}

The probiem of Harney Valley Paiute identity and territory cannot be separated from the problems of tribal distribution in the Northern Great Basin. From the beginning, trappers, traders and early explorers into the area used indiscriminately the terms "Paiute," "Bannock," "Snake," "Diggers," and "Shoshone" in reference to the Northern Paiute of Oregon, the Shoshoni-Bannock, and the Eastern and Western Shoshoni (Stewart 1966). Ethnographically it appears there is no agreement as to the composition of or location of bands in the Northern Great Basin area. Part of the problem stems from the fact that the groups have not been defined in terms of the same ethnographic present, and that reservation aggregates were confused with aboriginal groups (Fowler 1965). The problem was compounded by their lack of any well defined governmental structure or chief; leadership was based on one's ability to attract followers. The issue was further confused by bands being named after a major food staple, the area they normally occupied, or after a prominent leader. The nature of alleged territorial groups in this area has been under examination and disputed for years.

The classic argument among anthropologists on tribal distribution for this area has centered upon two interpretations of Great Basin social organization. Prompted by Indian Claims cases as a result of 
Indian Craims Commission Act (1946), extensive research was conducted as a basis for proving whether or not an identifiable group existed who had maintained exclusive use and occupancy of the land in question from time immemorial. On the one hand are those who maintain that clearly discrete bands with clearly divided territories occupied much of the Great Basin (0. C. Stewart 1966; Euler 1966). Others support the idea that the basis of society among the Basin Indians was a band of relatively small size composed of related persons who formed a household or camp group ${ }^{1}$ (Steward 1938, 1955). The forming of such a group was considered an adaptive strategy to the environment with bands as well as individuals tending to move freely throughout the territory, and with fusion and fission operating depending upon the supply of the resources (Fowier 1965).

Inter-Tribal Relations, Tradirg and Tribal Movements

The waadadikady were not an isolated people in Harney Valley. There is evidence that over the years they lived mostly at peace with neighboring peoples coming together with other groups more or less regularly each year.

It was reported to me that traditionaliy other Indian groups representing the Warm Springs Indians, the Bannocks, the Shoshone, the "Columbia River Indians," the Umatilla, and Surprise Valley Paiutes joined with the Harney Valley Paiute in coming to the Pine Creek root camip each spring. These groups converged upon this area in early May of each year for a period of about six week to engage in root digging unit.

IFowler (1965:111) coined the term "Kin-Clique" for this social 
and trade. Communicating through sign language they traded goods, including horses, furs, buckskins, blankets, beads, roots and obsidian. They also arranged marriages, raced horses, gambled, told stories and played games. Their dry camps were spread out away from one another among the juniper thickets, reportediy, much as I observed on recent field trips with Indians to the area. After the men had prepared their fish traps, they would move on to the fishery on the Middle Fork of the Malheur River to await the salmon run, often accompanied by people from the other groups. ${ }^{2}$

Horses were a desirable trade item. In September, 1875, Hopkins (1883:110) reported that Columbia River Indians came to Malheur Agency to trade, as they did every summer, horses for furs, blankets and guckskins. However, horses were often a source of contention. Indians from Malheur Agency complained to Hopkins (1883:139) that their horses had been stolen by either Columbia River Indians or Umatilla Indians. Captain Louie reported that when he was born (ca. 1830) the Umatillas used to steal horses from the Paiutes, and stole sixty from his father aione (Kroeber n.d.:6). ${ }^{3}$ The SaImon Indians (Warm Springs) bought horses from the Umatillas with one little basket full of beads for one horse. Thereupon the Warm Springs Indians raised their own, trading them with the Klamaths for round black beads. In turn, the Achomawi

${ }^{2}$ Hopkins (1883:138-139) reported that in May, 1879, Indians from the Malheur Agency were joined by fifteen families from Bannock Jack's band from Fort $\mathrm{Hall}$ at the fishery on the Malheur River.

${ }^{3}$ Captain Louie autobiography in unpublished M.S. of A. L. Kroeber n.d.:6. 
got their horses from the Klamaths (Kroeber n.d.:6) 4

The Warm Springs Indians told me that formerly they traded hides, salmon, huckleberries and horses to the Harney Valley Paiute for obsidian from Glass Butte. As recent as 1978 the Warm Springs Indians traded cash for roots from Pine Creek.

Stewart (1941:428) reports that the Kuiyui-eaters from Pyramid Lake brought pinon nuts to the Harney Valley Paiute in the old days to trade.

Reportedly, relations with other tribes were not always peaceful. They recalled to me ari incident involving a Paiute man and his son and a band of Bannock Indians. The pair were out hunting groundhogs in the vicinity of the root camp, and had a string of animals tied around their waists. They were forced to drop their heavy load when attacked suddenly from behind. They ran for a cave they knew in the rocks in a draw; and, with the father wounded, he ordered his son to shoot the chief in the eye. The son did as he was told, and the tip of the arrow made contact with the chief's eye. The rest of the band retreated, thereby allowing the man and his son to escape.

Conflicts often arose between bands over hunting rights and the capture of women. It was reported to me that traditionaily tribes stoie "young maidens" from each other. ${ }^{5}$

${ }^{4}$ Isabel Kelly (1932:151) had no data of the Surprise Valley Paiute trading with other Paiutes, but there was considerable trade between them and the western Achomawi. There was also trade with the Klamath and the Warm Springs Indians from whom they secured their first horses (a sack of camas or buckskin was bartered for a pony).

${ }^{5}$ Stewart (1941:404) reported marriage by abduction. 
Kelly (1932:184) reported that contact between the Surprise Valley Paiute and the Shoshone who Tived northeast of McDermitt appeared slight; but, the Bannock on one occasion joined with the Surprise Valley Paiute in a battle against the Klamath and Warm Springs Indians.

White Contact and Eariy Epidemics

With the initial white contact came diseases to which the indians had no resistance. The first appearance of an epidemic occurred the summer of 1830 along the banks of the lower Columbia River (Cook 1955), hitting the Central Valley of California in 1833, incapacitating most whites and decimating the native population. It may be this epidemic the Indians refer to when they speak to me of the "Mean 01d Witch Doctor and the Great Death" which occurred near Naneur Lake on two successive occasions about 1830.6 The circumstances surrounding this event are deeply imbedded in the memories of the older people, having been

${ }^{6}$ The account as was related to me follows: Once long ago, at the root camp the "witch doctor" Kadatwa sent his son to fetch some little woodpeckers who were nesting high in a juniper. When the boy put his hand in the hole he was bitten by a rattlesnake. His hand swelled up and he couldn't remove it; stranded, he remained there and was found dead four days later hanging by his hand. The angry "witch doctor" cried a!l summer long, mourning the death and blaming his own tribe for the tragedy, even though he had sent the boy to his demise. In the fall when the people had gathered together by the banks of Malheur Lake to collect waada seeds, the "mean old witch doctor" declared that he would destroy all his people. After his curse, most of the people lay dying in their beds. He repeated the curse the following year, deterinined to destroy the rest of the tribe. Captain Louie's (dcd. ca. 1930 at age 100) parents were destroyed in the second death while Captain Louie was still an infant sucking on his mother's breast. The few people remaining decided to destroy the "witch docior", and attempted to kill him with arrows; but, he ignored them and didn't die. With determination they took after him, captured him and put him on a huge sagebrush fire. He refused to burn right away and just curled up; finally ha burned to death. 
passed down through generations of oral history.

Additional epidemics followed including smallpox which touched the Columbia River region in 1847 (Mooney 14:743), and in the same year cholera hit the Humbolt River region (Northern Paiute), the effects of which were recorded by Hopkins (1883) as follows:

Almost all the tribe had died off... if one of a family got sick, it was a sure thing that the whole family would die... The white man had poisoned the Humbolt River, and our people had drunk the water and died off.

$$
\text { (Hopkins 1883:41) }
$$

The cholera epidemic of 1847 marked the end of the period of initial contact. 
CHAPTER IV

HABITAT

Division of Regions and Associated Resources

The area formerly occupied by the liarney Valley Paiute included a high plateau (+4111 ft. elevation $\left.{ }^{1}\right)$; Harney Valley which centered around Malheur and Harney Lakes and formed the interior basin of the plateau; numerous streams including Malheur River, Silvies River, Silver Creek, and Donner and Blitzen River; foothills surrounding the valley including Sagehen and Crow Camp Hillis; and the southern extremity of the Blue Mountains as well as the independent ranges of Warner Mountain and Steens Mountain.

Climatologically, the area is considered semi-arid and is characterized by cold winters, hot summers, and a relatively short frost free season with a high proportion of the annual precipitation falling as snow. Specifically the mean annual precipitation is $30 \mathrm{~cm}$.; January mean minimum temperature is $-11^{\circ} \mathrm{C}$; July mean maximum temperature is $31^{\circ} \mathrm{C} .^{2}$

Julian Steward (1938:17) described the flora of the area as that belonging to the artemisia belt of the Upper Sonoran zone, with the dominant desert shrubs including species of sagebrush (Artemisia sp.), rabbitbrush (Chrysothamnus sp.), shadscale (Atriplex sp.), hop-sage

${ }^{1} 1965$ U.S. Weather Bureau.

${ }^{2} 1960$ U.S. Weather Bureau. 
(Grayia spinosa), and species of salt desert shrubs near playas where alkaline soil prevails, including greasewood (Sarcobatus vermiculatus), shadscale (Atriplex sp.), seepweed (Dondia sp. and sueda sp.), and saltgrass (Distichlis sp.).

Reportedly, many areas now occupied by rabbitbrush and sagebrush had much grass, including wild rye and oats, ${ }^{3}$ before the introduction of cattle and sheep and being subjected to overgrazing (Steward, 1938). In addition, this area is characterized by grasses, willows, seeds and berries along lakes and streams, with edible roots abounding in the higher elevations northwest and northeast of the valley in the spring time. Ponderosa pine is prevalent in the higher elevations north of the Valley, and juniper and mountain mahogany grow above 5000 feet.

Though many of the above resources were seasonally limited in availability, the following represent faunal resources which were potentially available for harvest all year round: deer, mountain sheep, and antelope were found in the foothills; the jackrabbit was common everywhere; groundhog, porcupine, and other rodents abounded as well as furbearing animals including beaver and otter; trout and other nonanadromous fish were in streams; and Malheur Lake attracted herds of buffalo in years past. ${ }^{4}$

In addition, Malheur Lake attracted migratory birds, and salmon

${ }^{3} 1872$ Report on Indian Reservation Lands in Oregon.

4Peter Skene Ogden, (Binns 1910) explorer, noted buffalo heads along Malheur Lake in November, 1826. Captain Louie (Bailey 1936:60) recalled that old men wore robes of much-worn buffalo skins when he was a child (ca. 1835) and that when the buffalo left the area about 100 years before, the Indians subsequently followed them east across the Snake River into Bannock country. 
migrated to the upper forks of the Malheur River.

Though not considered a food resource, Bailey (1936) recorded the gray wolf or plains wolf (Canis lycaon nubilus) was also present in the Valley. ${ }^{5}$

This complex area with its diverse regions and varied resources may be explained by viewing it environmentally in terms of physiography, geology and soil analysis. Characteristically, the area has both the peculiarity and the advantage of lying amidst four physiographic provinces outlined by Baldwin (1964) and Fenneman (1931), as follows: High Lava Plains, Basin and Range, Owyhee Upland, and Blue Mountains (Figure 3). Though the boundaries of such are arbitrary and gradua 1 transitions exist, this resulted in a relatively heterogeneous and complex situation, and undoubtedly contributed to the richness of the food resource base formerly located there and utilized by the Harney Valley Paiute.

\section{Seasonal Round}

The Harney Valley Paiute utilized a wide range of local resources including seeds, roots, fish, small game, deer, elk, and bison. The general pattern was one of intensive exploitation, probably by small family-based groups similar to those reported among the Owens Valley Paiute (Steward 1933) and the Surprise Valley Paiute (Kelly 1932).

Prior to white contact the Harney Valley Paiute wintered in small camps near spring sites in the vicinity of MaTheur Lake. The people

\footnotetext{
${ }^{5}$ Reportedly, as late as 1915 "sheepwolves" roamed the eastern part of the valley, and the residual sheep skins were sought after by the Indians.
} 


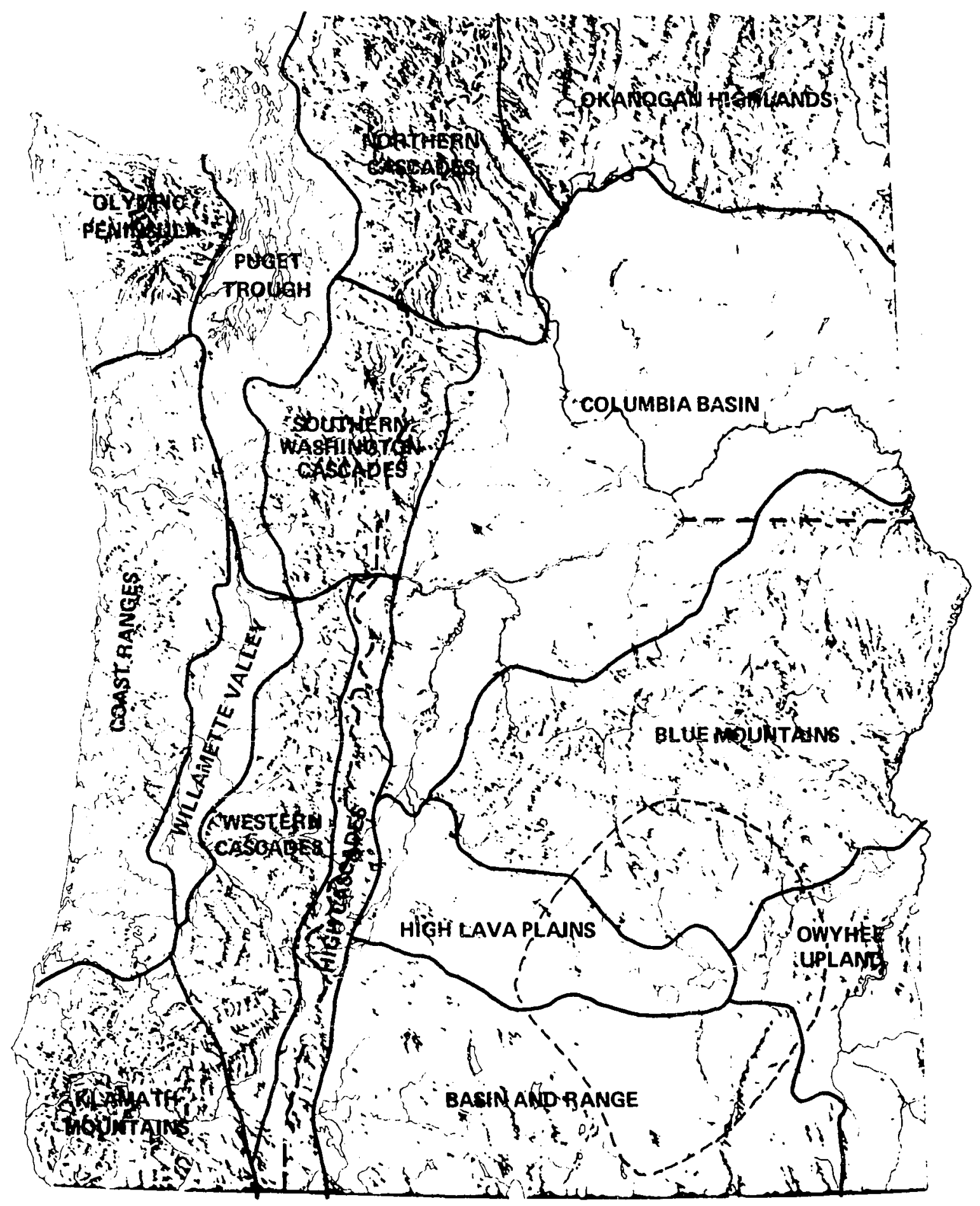

Figure 3. Physiographic and geological provinces of Oregon and Washington (Baldwin 1964, Fenneman 1931, and Esterbrook and Rahn 1970 in Frankl in and Dyrness 1973). Also Harney Valley Paiute territory. 
journeyed to Pine Creek in the northeastern corner of Harney Valley in early May. They knew the edible wild roots would soon be ready for gathering and they longed for the reunion with other people who would join them from far away representing the Warm Springs Indians, Bannocks, Shoshone, "Columbia River Indians," Umatilla, and Surprise Valley Paiutes. Their dry camps were spread out for several miles, seeking the shade of the junipers. During this time they re-established relationships, engaged in root digging, and trading. The women dug roots while the men prepared to move on to the Middle Fork of the Malheur River to set up their salmon traps.

While their habitat did not permit them to accumulate a surplus, it did offer enough diversified resources to sustain them. At Pine Creek the following plants were gathered in the spring:

koogi (Calochortus macrocarpus Dougl.)

kanicy (Lewisia rediviva)

paazigo (Camassia quamash)

cuka (Lomatium cous)

canacuka (Lomatium canbyi)

kwidapoo (Lomatium gormanii)

haapi (Lomatium macrocarpun) ${ }^{6}$

Native term unknown (Lomatium nudicaule)

yapa, yampa, payapa, suiyapa (Perideridia bolanderi)

pamahayapa (Perideridia oregana Wats.)

sii (Allium madicum Wats.)

${ }^{6}$ Huunibui according to Whiting (1950:17). 
kyyga (AZZium acuminatum)

Native term unknown (AZZium macrum)

winida (Fritillaria pudica)

poziidapy (Trifolium macrocephalum)

pakwana (Mentha arvensis)

wodaa kwasiba (Achillea millefolium)

namogot (Pentstemon sp.)

Atter their skin sacks were full of roots, the women moved on to Malheur River to assist the men in catching and drying salmon.

When the run was over the group broke up with families wandering off by themselves into the forest to hunt birds, deer, elk, and to gather seeds and roots as they ripened elsewhere. Aki (Wyethia) and kusiaki (Balsamorhiza hookeri Nutt) were among the first seeds to ripen with aca (Sisymbrium sophia) ${ }^{7}$ ripening later. Both grew in large quantities near Harney in the northern part of the valley. Throughout the summer foraging continued with families in search of groundhogs and berries. Acapui (Ribes cereum) was a favorite and was found in the hills near Pine Creek and along the banks of the Silvies River. They traveled as far away as Dixie Butte near Canyon City to collect tckaponoma (Vaccinium membranaceum) while the men hunted for elk.

By late August families turneú soiuth and headed towards Malheur Lake to be on hand when the waada (sueda depressa) ripened. Here on the northeastern shore of Malheur Lake large numbers of people congregated to gather the tiny black seeds and join in the festivities. Other seeds were gathered in the fall, including guuha (Mentzelia)

${ }^{7} \mathrm{~A}$ European intrusion. 
and tyba (Pinus ponderosa), in the forests north of the valley. Many people went to Crow Camp Hills from the lake to pick pokopisa (dooisabui [Prunus virginiana]). At this time there were also communal rabbit and antelope drives.

By November the families gathered together their cached goods and set up their tule mat houses near springs and a supply of wood in preparation for winter. Whiting (1938) recorded that the people of Harney Valley had winter camps in Silver Creek, Harney, Diamond, Blitzen, Roaring Springs of Catlow Valley, Suntex in Silver Creek Valley and a questionable camp at Wild Horse Creek.

While this does not present a complete picture of their subsistence cycle and seasonal round, it does put some of the more important subsistence pursuits in seasonal context, and divides the year into two parts: that spent moving in temporary camps while they exploited the diverse resource base, and that spent in more permanent winter camps.

\section{Place Names}

Ther: are a number of names for minor features of the environment which were important to the Harney Valley Paiute. Such names are invariably descriptive and refer to some plant, animal or important feature that was formerly seen there, as follows: ${ }^{8}$

Muddy-dance place (Diamond Valley)

Black Point (Wright's Point)

Nigger Flat

Rock Fort (Barren Valley)

${ }^{8}$ The native names were not available. 
Soldiers' Earth House (Camp Lyons)

Red Top Mountain

Standing Rock (Castle Rock)

Fish trap

Alkali Spring

Wild Currant Creek

Cattail-flag

Happy Valley

Eagle's Nest

Water Cave (Malheur Cave)

Chokecherry Springs

Coyote Point

Sagehen Hills

Crowcamp Hilis

Pine Creek

Big River (Snake River) 


\section{CHAPTER $V$}

\section{SUBSISTENCE AND THE ROLE OF PLANTS}

\section{Hunting and Fishing}

Although plants were of primary importance, in post-horse days, at any rate, deer, elk, bison and mountain sheep were taken reguiarly by the perseverance of single hunters 0 small groups in localities favored for hunting (Steward 1938). Families went towards Seneca and John Day to hunt deer in the timber, and in the fall to Canyon City to hunt elk while the women picked huckleberries. Reportedly, whenever they were hungry, a man would go out for a deer and come back with one laid ovei the horse. It would be cut up, dried with salt and sacked up, the fat kept separate to eat as "butter." Similarly, bison (Bailey 1936:60) were reportedly plentiful over Harney Valley in the early 19th Century, and as late as 1936 Bailey recorded that the Burns Indians still had a song calling the buffalo to "come back, come back and do not go away again."

Small game was of relatively great importance and is to a lesser degree today by those that hunt. Rodents were popular with the groundhog, prairie dog, squirrel, jack rabbit, porcupine, and beaver most preferred. Hunting dogs were frequently used to chase rodents into their hole, but the key to taking any smal1 animal was "patience."1

\footnotetext{
${ }^{1}$ In hunting groundhogs, one waited patiently by the hole for the
} 
In addition, squirrels were taken with a sling shot by boys, or porcupines were caught in the dark with either a club or a gun, then dragged home with a rope and prepared similarly to a groundhog. A comb was made from the tail of a porcupine.

Fishing was mostly done in the vicinity of Drewsey, Logan Valley, and Malheur Lake. The Malheur River and its tributaries were frequented during the spring salmon run, ${ }^{2}$ at which time traps of tied willow bundles were rolled into the river, and the women assisted by sitting on the trap, submerging it until a fish entered. Subsequently the fish was pulled out, hit on the head and placed into a burden basket. Kelly (1932) reports this event more vividly, as follows:

...wi'ha' with constricted neck was known; it was described as a stiff willow "sock-like" basket, five to eight feet long and three feet in diameter at the mouth... used especially by the Malheur Paiute. A woman held the contrivance in the stream while the men or boys frightened the fish toward her. When she felt a fish enter, she snatched the basket from the water, knocked the fish with a club, and placed it in a burden basket. Fish were not allowed to struggle because they would tire and taste badly.

Keily 1932:80

In addition trout and smaller fish were caught in the mountains

animal to reappear. Sometimes the dog chased the animal up a juniper tree, making it necessary to smoke him out. The dog was quickly dispatched to prevent his eating the animal. The tool used for extracting the groundhog was a stiff wire approximately twelve or fourteen inches long with a sharpened hook on one end and a wooden or juniper handle on the other. The Surprise Valley Paiute (Kelly 1932:87) similarly used a sharpened straight stick or a hooked stick. The hook was inserted down the hole and hooked in the groundhog's mouth or neck. Then the wire was kept taut while the groundhog planted his feet. The snare was pulled hard until he appeared, and ther he was hit on the head with a club. The forel imbs were folded back, thereby breaking the veins, resulting in a quick death.

${ }^{2}$ Species is unknown but is presumed to be Chinook species because of the great distance from the Pacific Ocean. 
on the upper Malheur River. Tiny white ant eggs were thrown in the river to lure the fish and draw them out. The fish were eaten fresh or dried for winter use. In the winter fishing was done predominately near the Narrows of Malheur and Harney Lakes. Reported7y, the men used a snare of sagebrush bark with which to fish and wore sagebrush overshoes over their moccasins to keep dry. Meanwhile, the women gathered dried greasewood for fire, building it near the water's edge for the men to come and warm themselves.

Insects were considered a valued food source at times. According to Whiting (1936) around the middle of July families congregated at Cow Creek to gather crickets. The women went out early in the day to gather them, and subsequently roasted, dried and pounded them to be cached in bags for winter. In addition, red ants were collected to form a pudding. Hannah Pete collected them until her recent death. It was explained to me that the Indian way of life was patterned after the lifestyle of ants: It was proper to work from spring until fall, collecting food and wood, and store it away in preparation for winter. Those that didn't do that would suffer the consequences.

Reportediy, the utilization of animal resources for food did not extend to nor include the use of skunk, lizards, snakes, eels or dogs.

The Importance of Plants

Plants played a major role in the diet and in the material culture of these Indians in the past. The basic plant foods included roots, greens, berries, and seeds. A variety of other plants were collected for use in material culture, specifically for building shelters and as weaving materials, including saiby (Scirpus sp.), toiby (Typha sp.), 
waiya (Elymus cinereus) and syybi (Salix sp.). Sawabi (Artemisia tridentata) was used in making cordage and as a major source of fuel, and waapi (Juniper occidentalis) was used in the manufacture of bows.

A number of native plants were used for medicinal purposes including waapi ( $J$. occidentalis) and sawabi (A. tridentata) for cold and flu symptoms. Wodaa kwasiba (Achillea millefolium) was applied topically to sores and wounds. Unfortunately, many of the healing remedies, including mixtures and combinations of various plant parts, remain a secret among the older people, and this information is not readily shared with the younger generation.

In addition, an assortment was used for drinking, cliewing, and smoking, i.e., pakwana (Mentha arvensis) madp a refreshing tea; sigupi (Chrysothammus nauseosus) sap was chewed like gum; and, puihibamo (Nicotiana sp.) was smoked.

In addition to the importance of plants on diet, health and material culture, other aspects of culture were influenced by the annual migration for plants, for instance: the conceptualization of time. To demonstrate, the following phrases reappear frequently:

We checked the roots two weeks ago but they weren't ready. It wasn't time.

Eventually all of the houses of the village will move up on the hill to join the new community center. In time this will happen.

The groundhog we killed wasn't ripe yet. It wasn't time. Note also how the descriptive plant term "ripe" is applied to describe an animal in terms of its readiness to be eaten.

Furthermore, their calendar appears to have been organized taking the annual migration for food resources into consideration. From omer 
Stewart's (1941) Culture Element Distribution List, we find that the calendar listed names of lunar months (each month starting with the new moon) which translate into a brief description of characteristic activities or seasonal conditions for each month, as follows:

First-green-shoots-through-snow-month

Grass-grows-high-month

Indian-potato-month

Salmon-month

Spring-month or groundhog-shadow-month

Cold month

Stewart 1941:445

It is apparent that the annual migration was dependent upon the seasonality, availability and correct time for gathering plant and animal species; and more specifically toward the collection of plani species, and, to a lesser degree, animal species.

\section{Division of Labor}

A general statement can be made regarding subsistence and the traditional sexual division of labor. Hunting was the province of men, but women assisted in communal drives and also took small game such as groundhogs. Men made the equipment for the hunt including the manufacture of stone tools, nets, and twisted the bark fiber for cordage (Stewart 1941:389). They also prepared the willow trap for fishing while women cooperated in retrieving fish from the trap and prepared it for drying.

Women's role centered upon domestic tasks, the gathering of wild plants for food, and the gathering of insects. The preparation of food for storage, hauling of wood and water, cooking, sewing, hide dressing, weaving of rabbit-skin blankets, basketry and cradleboard manufacturing were preeminently a woman's work. 
House building was a cooperative venture, with men setting the frame and women applying the covering.

The division of labor extended to children. Boys learned to hunt, make their own bows, arrows and sling shots, while girls learned to dress hides, sew, cook, prepare meat for drying, gathered roots, tended small children, all in preparation for a productive adult life. 


\section{CHAPTER VI}

\section{PLANTS USED ${ }^{1}$}

The following puges of this section include a description of forty-one plants that were used by the Harney Valley Paiute.

Because many of the plants have multiple uses and because of the confusion surrounding common names, the plants utilized have been organized alphabetically according to the native term.

I relied upon Hitchock and Croquist (1973) for information relating to plant description, habitat and distribution.

Unless otherwise specified the "Indian Use" refers to that of the Harney Valley Paiute.

Also included is information relating to gathering techniques and implements used, methods of preparation, and methods of preservation including drying and storage.

For reference, a Dictionary of Plant Names is included in the Appendix which is arranged aiphabetically according to Common Name and gives information on general use.

${ }^{1}$ Including native, botanical and common name; description; habitat; distribution; Indian use; techniques and implements used; preparation including processing and grinding; preservation including drying and storage. Organized alphabecically according to native terms. 
Native term: aca (red [Figure 4])

Descurainia sophia ${ }^{2}$ (L.) Webb. (Cruciferae

Sisymbrium sophia

Common Name: Tansymustard

Description: A tal1 annual (3-10 dm.) with deeply cleft leaves and linear siliques containing more than 20 seeds.

Habitat: $\quad$ bry open fields, meadows and waste ground.

Distribution: A European intrusion from Alaska to California (Hitchcock and Cronquist 1974:161).

Indian Use: The "little red seed" was collected in the same manner as waada. ${ }^{3}$ The seeds were then placed in a finely woven willow basket with pine pitch covering the outside, and a hot coal was stirred around in the seeds by hand. The seeds made a noise, jumping as they cooked, and were mashed with the hands. Subsequently they were winnowed and ground by hand on a metate. A little water was added to the resulting flour and stirred to prevent the mixture from becoming lumpy. A little sugar was added, and the mixture was eaten as a gruel or mush. Another species, the "tall one", was characterized as bitter. ${ }^{4}$

It was reported that the Surprise Valley Paiute (Kelly 1932:98) mixed "atsa" with snow, making a "sort of ice cream", and Chamberlin (1964:340) noted that the Gosiute also mixed the tiny red ground seeds with snow to make a "kind of confection".

${ }^{2}$ Because Descurainia sophia is intrusive, aca may represent another species which is indigenous to this area.

${ }^{3}$ See waada (Sueda intermedia) in this section.

${ }^{4}$ Possibly sisymbrium altissimum. 


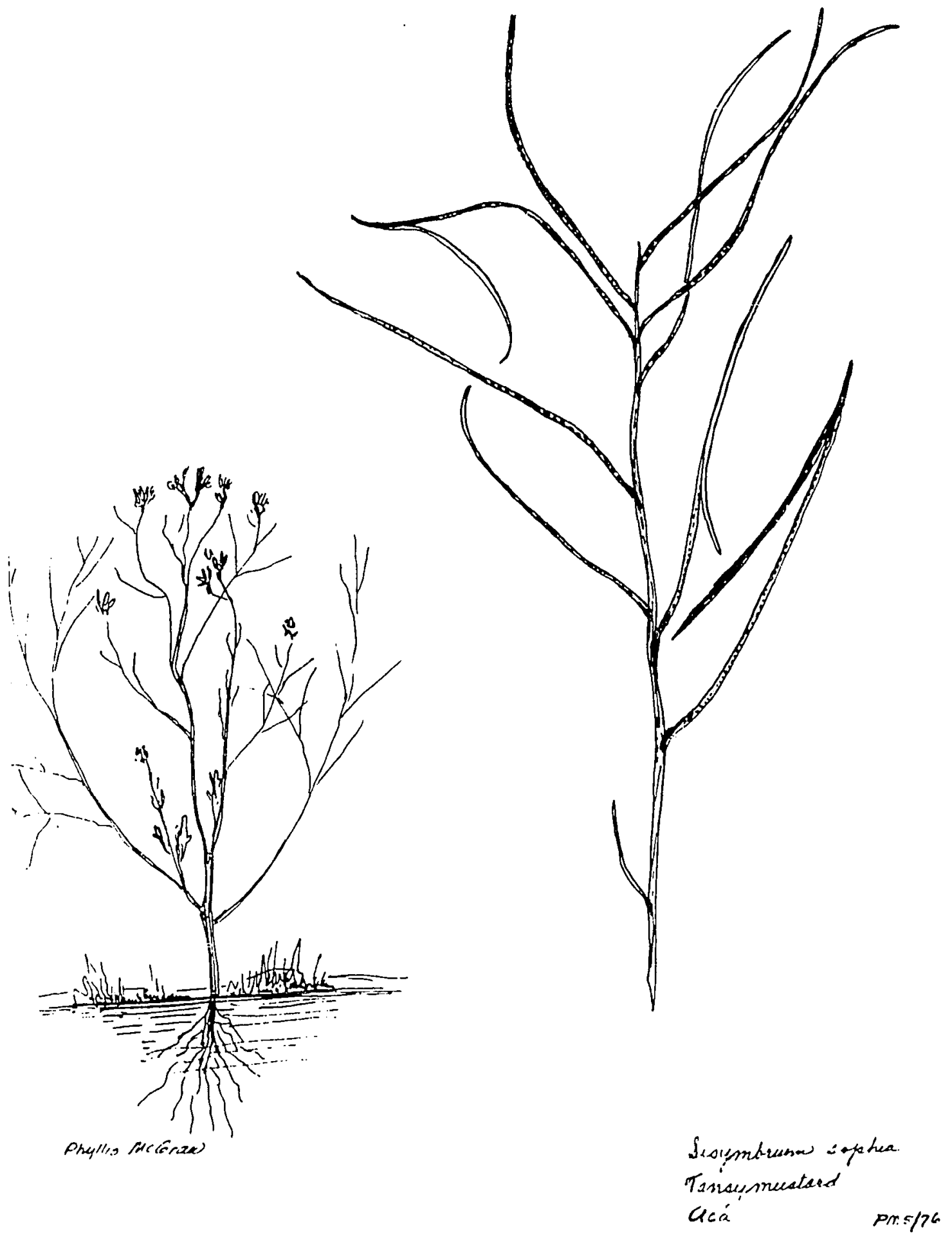

Figure 4. Aca (Descurainia sophia) tansy mustard. 
The Owens Valley Paiute (Steward 193\%:242) designated Radicula curvisiliqua (Hook.) as "atsa", and grew the western yellowcress on irrigated land.

Native term: acapui

Ribes cereum (Grossulariaceae)

Common Name: Squaw currant

Description: Spineless shrubs with alternate, palmately veined leaves, pink flowers, and reddish berries which ripen in early JuTy.

Habitat: $\quad$ Stream banks and wâshes in grasslands, sagebrush desert to ponderosa pine forest.

Distribution: Eastern slope of Cascades from north central Washington to California (Hitchcock and Cronquist 1973:202).

Indian Use: Wild currants are either eaten fresh, dried, or sugar is added to make a syrup or jam. ${ }^{5}$

The Surprise Valley Paiute (Kelly 1932:100) always threw a handful of dust on a "atsapui" bush to prevent getting a headache. They also threw dust on a plant to prevent birds from being attracted to the fruit.

Native term: $a k i^{6}$

Wyethia sp. (Compositae)

50ne woman recently collected some "berries that bears eat" which remained quite sour in spite of the addition of lots of sugar. This may refer to a "bears' currant which is quite pungent" (Catherine Fowler, personal communication). 428).

${ }^{6}$ Unidentified but assumed to be Wyethia sp. by Stewart (1941: 
Common Name: Wyethia, MuTe's Ears

Description: A taprooted herb with yellow or white flowers which resemble sunflowers.

Habitat: Depending upon the species, varies from open hillsides to dry or moist meadows, ranging in elevation from foot hills to mid-elevations.

Distribution: East of Cascades (Hitchcock and Cronquist 1974:557).

Indian Use: The seeds of the plant were primarily eaten.

For the Surprise Valley Paiute (Kelly 1932:98), the principal gathering grounds of $w$. mozzis Gray were in Goose Lake Valley. They utilized the stems as well as the seeds and ate them raw. Also, ground seeds were mixed with mashed fresh Service berries or with dried berries that had been soaked. Medicinally (Kelly 1932:196-7), crushed leaves were applied as a poultice to sprains, broken bones, and to reduce swelling. A tea of boiled leaves was taken for stomach ache.

Native term: cana-cuka $^{7}$ (Figure 5)

Iomatium canbyi ${ }^{8}$ (Umbel1 iferae)

Common Name Biscuit root

Description: A perennial with spherical thickened root up to $3.5 \mathrm{~cm}$. thick. The finely divided Teaves are grayish green and the fiower is white. The Indians claim it has a unique odor (though I could not detect it).

\footnotetext{
${ }^{7}$ Translation: sweet cuka.

${ }^{8}$ Lomatium canbyi is alternatively referred to as "haapi" by some.
} 


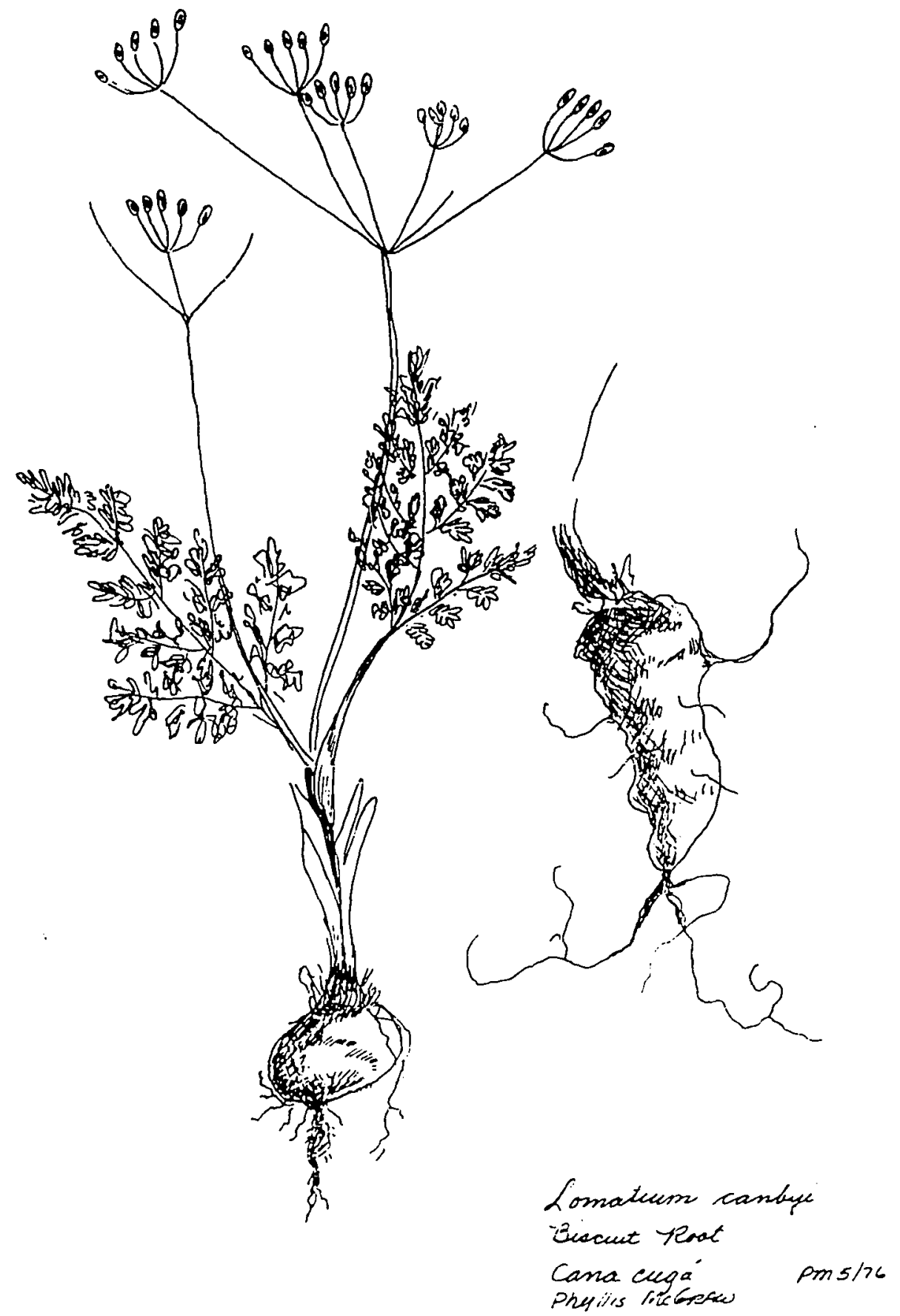

Figure 5. Cana-cuka (Lomatium canbyi) biscuit root. 
Habitat: $\quad$ Rocky soil in exposed sunny areas in association with Lomatium cous, Allium sp., Lewisia rediviva, and Artemisia tridentata at approximately 4800 feet elevation.

Distribution: Southeastern Washington and Oregon east of the Cascades extending to Nez Perce County, Idaho (Hitchcock and Cronquist 1974:332).

Indian Use: This is a highiy desirable root of the Harney Valley Paiute but it relatively scarce. It is prepared and stored in the same manner as cuka.

Kelly (1932) reported that tsana-tsuga (unidentified) used to grow in the high country east of Surprise and on the hills of Bidwell Canyon (Kelly 1932:103).

Native term: cinabi

Populus tremuZoides Michx

Cormon Name: Aspen, quaking aspen

Description: Smooth white barked tree.

Habitat: Mountains and occasionally stream banks.

Distribution: East of Cascades from Alaska to California (Hitchcock and Cronquist 1973:65).

Indian Use: Hides were spread over the smooth white bark of an aspen trunk and worked. This bark was preferred because it prevents hides from splitting.

Native term: cuka (Figure 6)

Lomatium cous (Umbelliferae) 


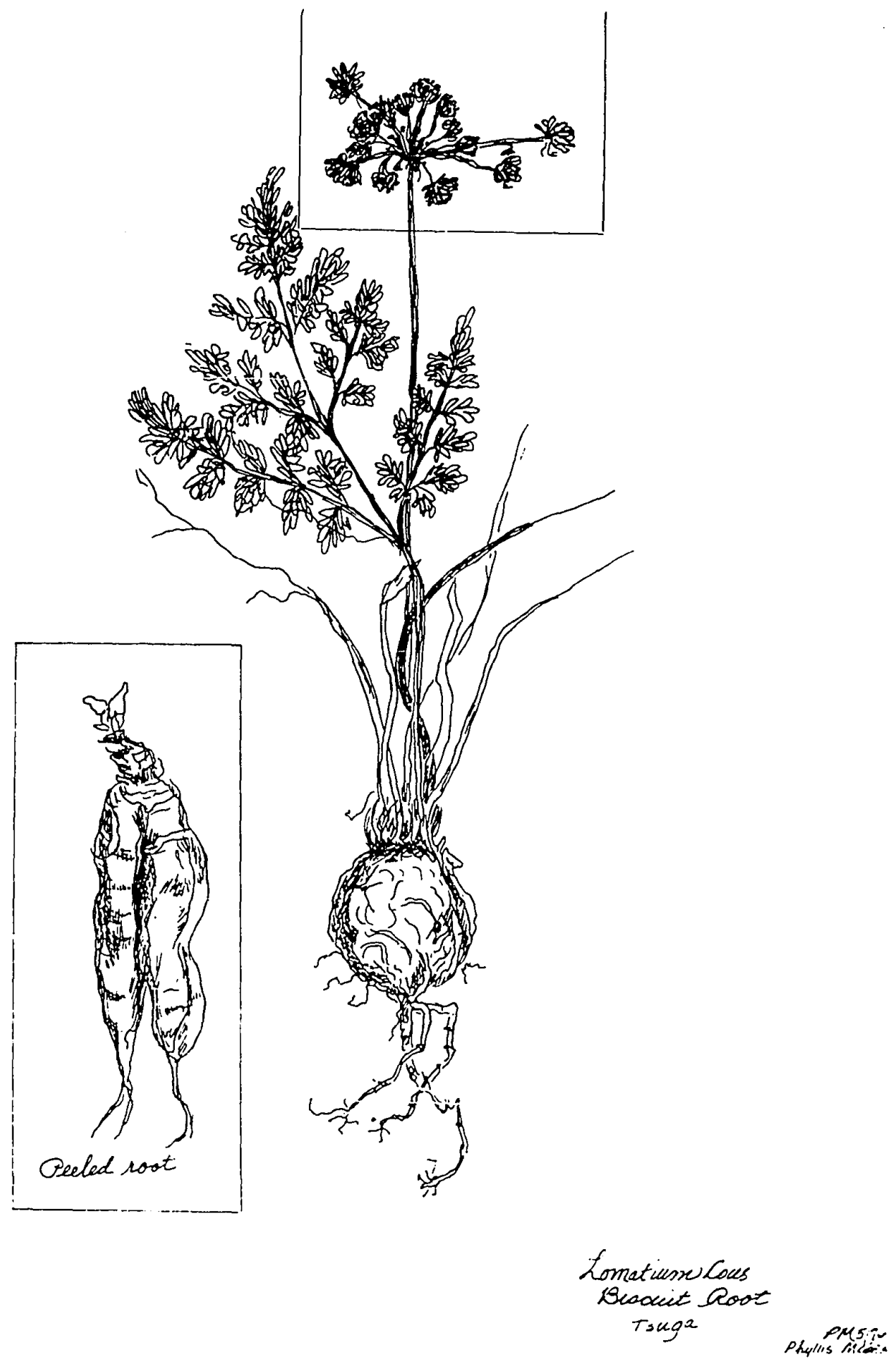

Figure 6. Cuka (Lomatium cous) biscuit root. 
Common Name: Biscuit root; ${ }^{9}$ cous

Description: A perenniai with thick tuberous roots, finely divided leaves, and a leafless stem which bears terminal compound umbels with yellow flowers.

Habitat: $\quad$ Coarse sandy or rocky soil in exposed sunny areas in association with AlZium sp. and Lewisia rediviva at approximately 4800 feet elevation.

Distribution: East of the Cascades in southern Washington and Oregon extending across Idaho to Montana and northern Wyoming (Hitchcock and Croquist 1974:329).

Indian Use: The preferred time for digging this profusely growing and desirable root is when the flower is flooming (Figure 7) and the tuber is firm and fleshy. The black skin slips easily if the root is kept cool and moist after digging. The plants are usually deposited in a canvas bag, kept in the shade until peeled and then rinsed in creek water (Figure 8). Cuka is eaten raw, dried, boiled, or sliced and fried like potatoes. It may be ground into flour, made into mush or bread-like goods, or while still freshly ground and moist, may be formed into small patties called "three finger" or "palm" cakes and subsequently dried in the sun. These were carried by hunters in a small skin pouch tied to their waist. While the roots were formeriy stored in bucksin bags, now they are stored in flour sacks. If they are not permitted to dry fully, they turn black in color.

Nutritionally, a one cup serving of fresh cuka provides $1 / 3$ the

90ther biscuit roots are represented by Kwidapoo (Lomatium gormanii) and haapi (Lomatium macrocarpum). They are treated in the same münner as cuka. 


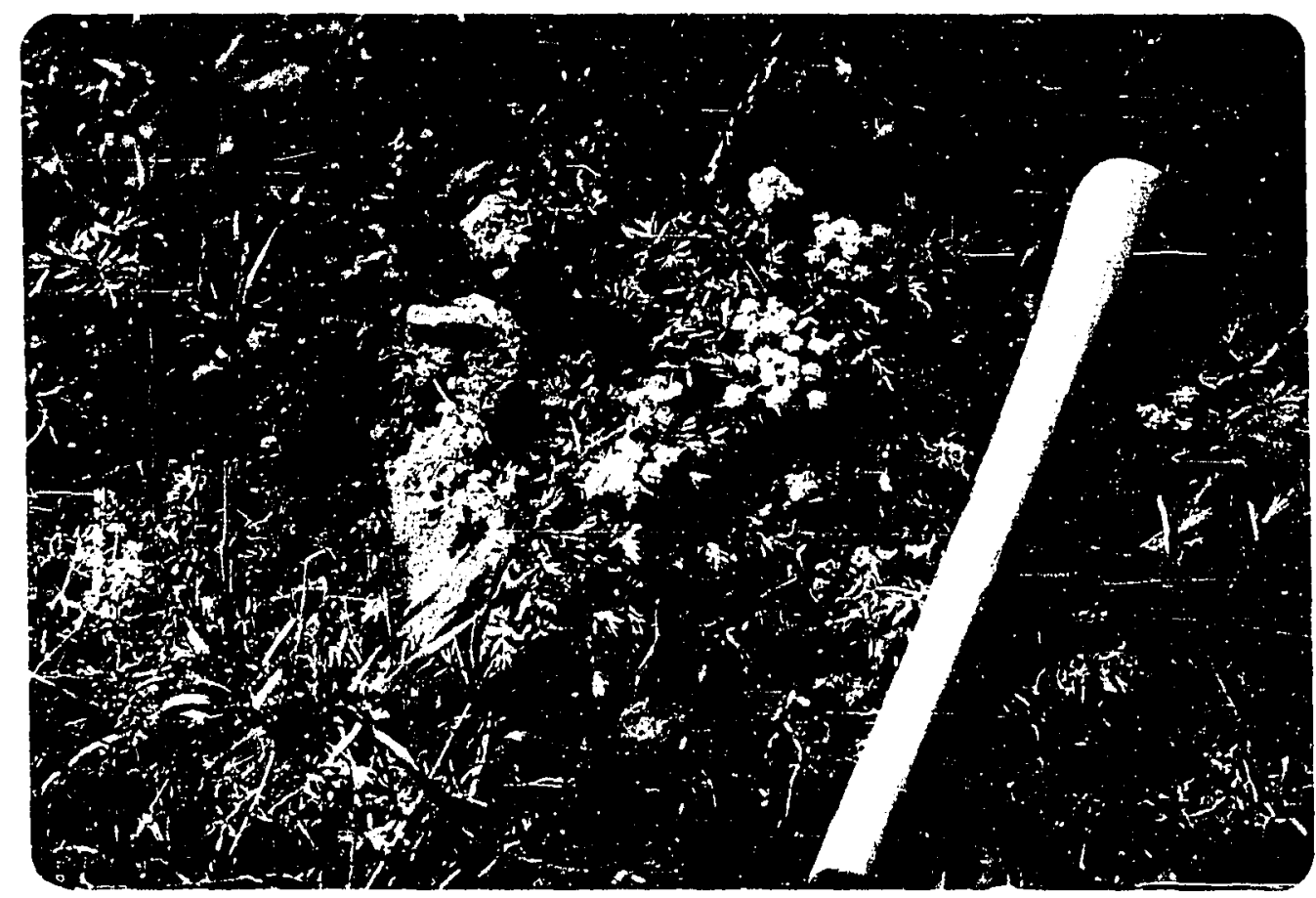

Figure 7. cuka (Lomatium cous) biscuit root in bloom and digging stick handle. 


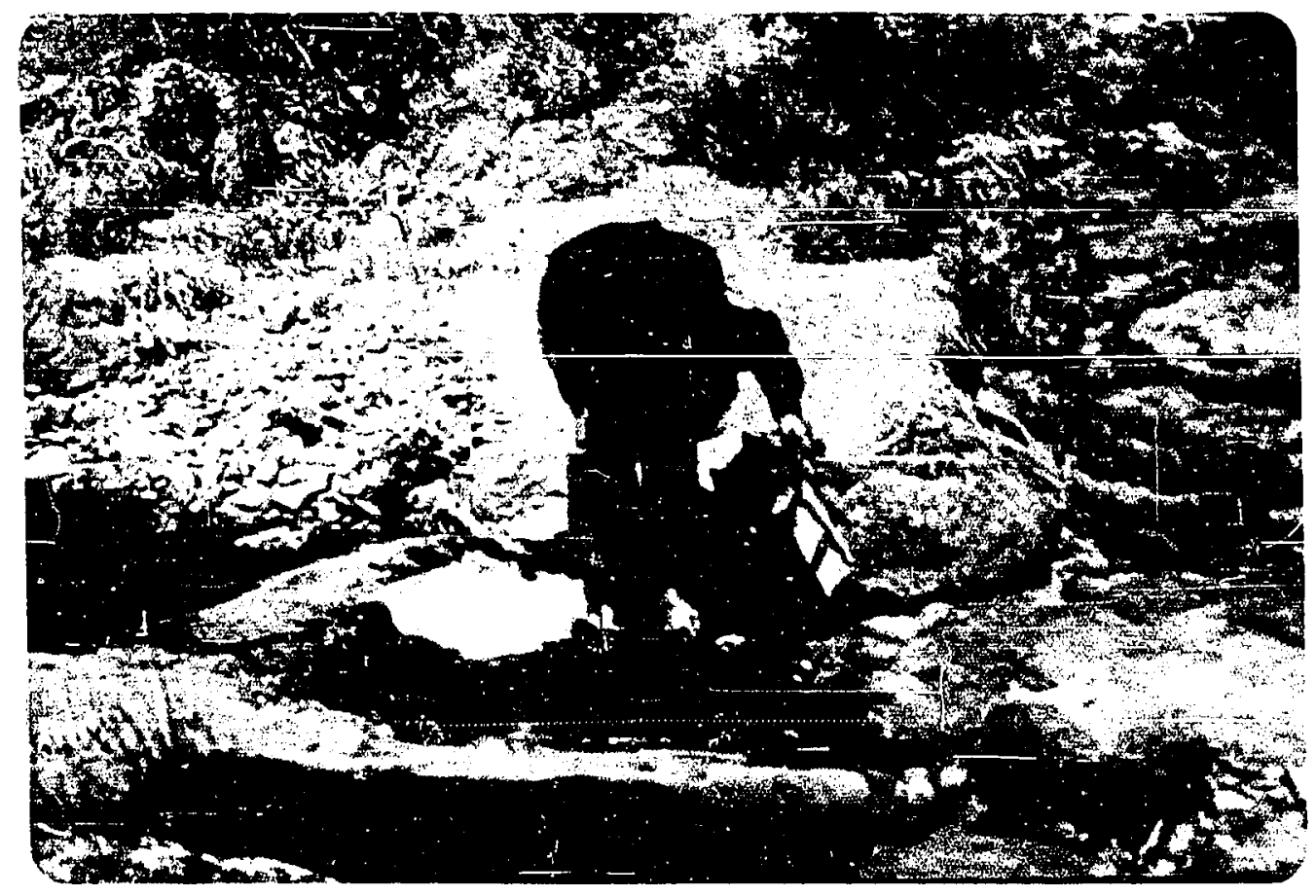

Figure 8. Paiute root digger rinsing roots in Pine Creek. 
recommended daily allowance of vitamin $C$ which decreased in the frozen product and disappears completely when dried, and 1/3 to 1/5 RDA of iron (Extension Circular 809:12).

Native term: guuha

Mentzelia Laevicaulis Doug1. (Loasaceae)

Common Name: Blazing Star; Stickleaf

Description: A perennial herb with five showy yellow petals; stems and leaves are covered with harsh sticky hairs which adhere to any object touched.

Hábitat: Dry talus slopes and gravelly sagebrush plains.

Distribution: East of the Cascades from British Columbia to California (Hitchcock and Cronquist 1974:300).

Indian Use: Both the Harney Valley Paiute and the Owens Valley Paiute ${ }^{10}$ utilized the seed clusters of the large yellow flower. According to Steward $(1933: 243)$ the seed clusters were dried on fiat rocks, threshed, and the seeds were subsequently parched and ground on a metate into flour to be used as most other seeds.

For the Surprise Valley Paiute (Kelly 1932:98) guuha was represented by $M$. albicaulis Dougl., an annual with tiny flowers.

Native term: Kanicy (Figure 9)

Lewisia rediviva (Portulacaceae)

Common Name: Bitterroot

Description: Succulant perennial herb with three or more fleshy

${ }^{10}$ Species unidentified by Steward (1933:243). 


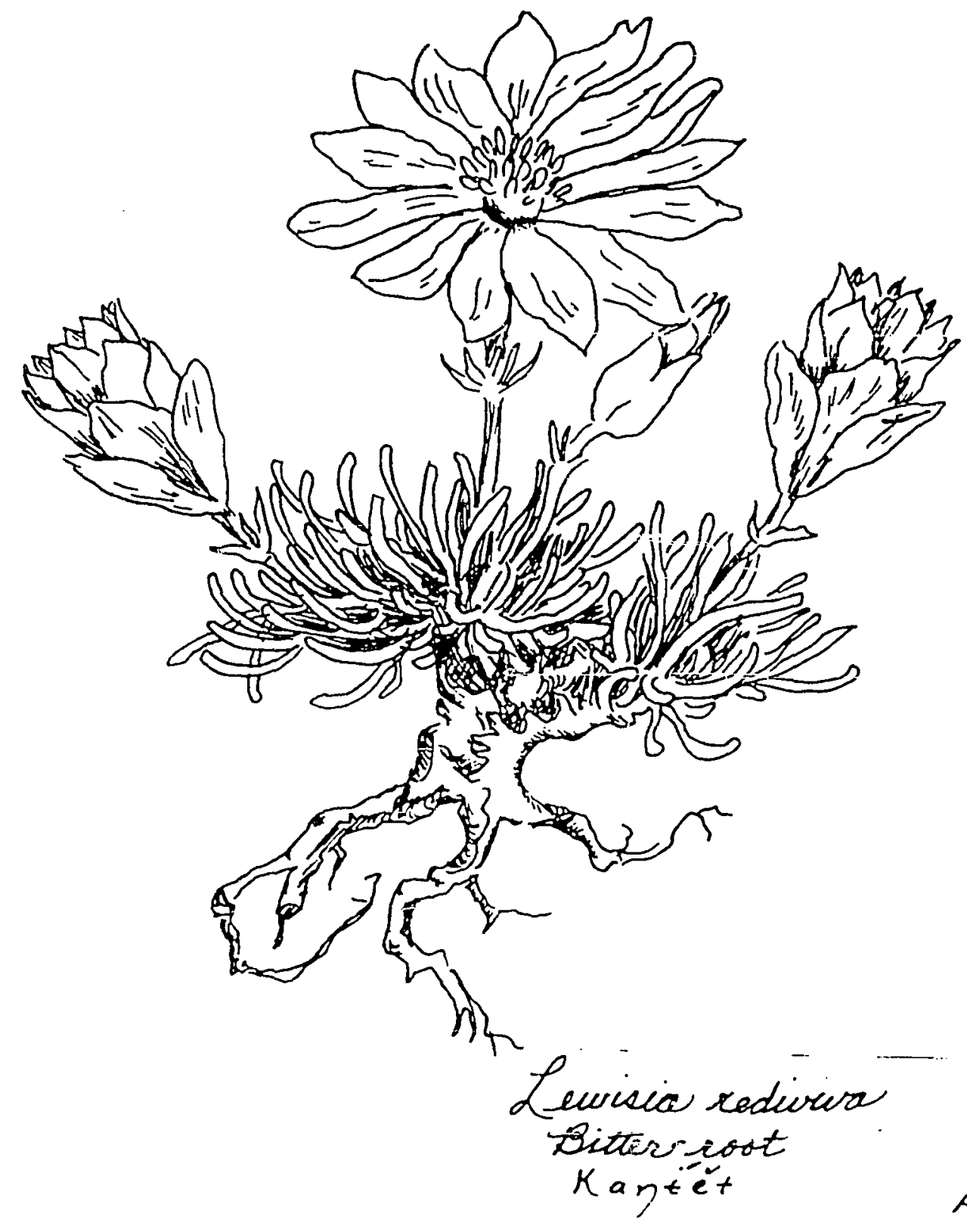

PMgto

Figure 9. Kanicy (Lewisia rediviva) bitterroot. 
carrot-shaped roots.

Habitat: $\quad$ Coarse rocky soil in sunny exposed areas in association with Artemisia tridentata, Lomatium cous and Allium sp. at approximately 4800 feet elevation, frequently in groups of $8-10$ bitterroot plants.

Distribution: East of Cascades in Washington and Oregon (Hitchcock and Cronquist $1974: 106)$.

Indian Use: Bitterroot is a highly preferred plant by the older members and commonly referred to by the English term. Best dug when the tiny red buds are present (Figure 10), the skin slips easily from the root. Waiting until the plant is more mature results in toughened roots and more difficult peeling. Upon collecting they are kept cool and moist in a bag to be peeled later in the shade. They are then spread in the sun and wind to dry (Figure 11) and within several hour's are beautifully bone white in color; if dried in the shade they turn reddish in color and bitter. Bitterroot varies in taste according to the soil in which it grows, and are always sampled before investing a lot of work for some "bitter bitterroots". They are preferred eaten as dessert with milk and sugar, having been boiled first. In addition, they may be dried and pounded for flour on the metate.

Kelly (1932:102) reported that the Surprise Valley Paiute boiled kanutcu "like macaroni".

Nutritionally, bitterroot has a significant amount of vitamin C, with one cup of fresh providing the recommended dietary allowance which reduced to about 1/3 RDA in the dried product (Circular 809:9). 


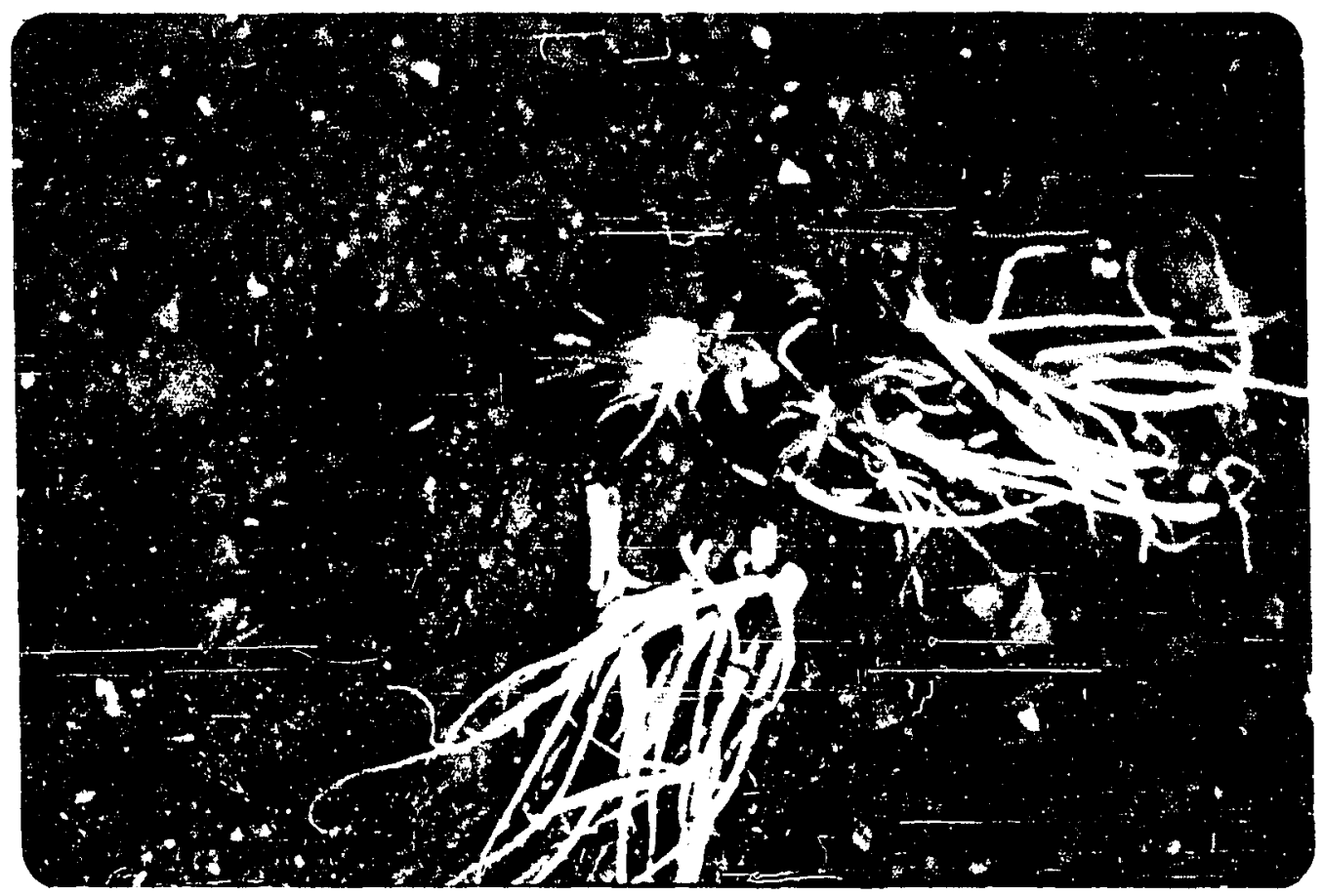

Figure 10. Kanicy (Lewisia rediviva) bitterroot at the bud stage and peeted roots. 


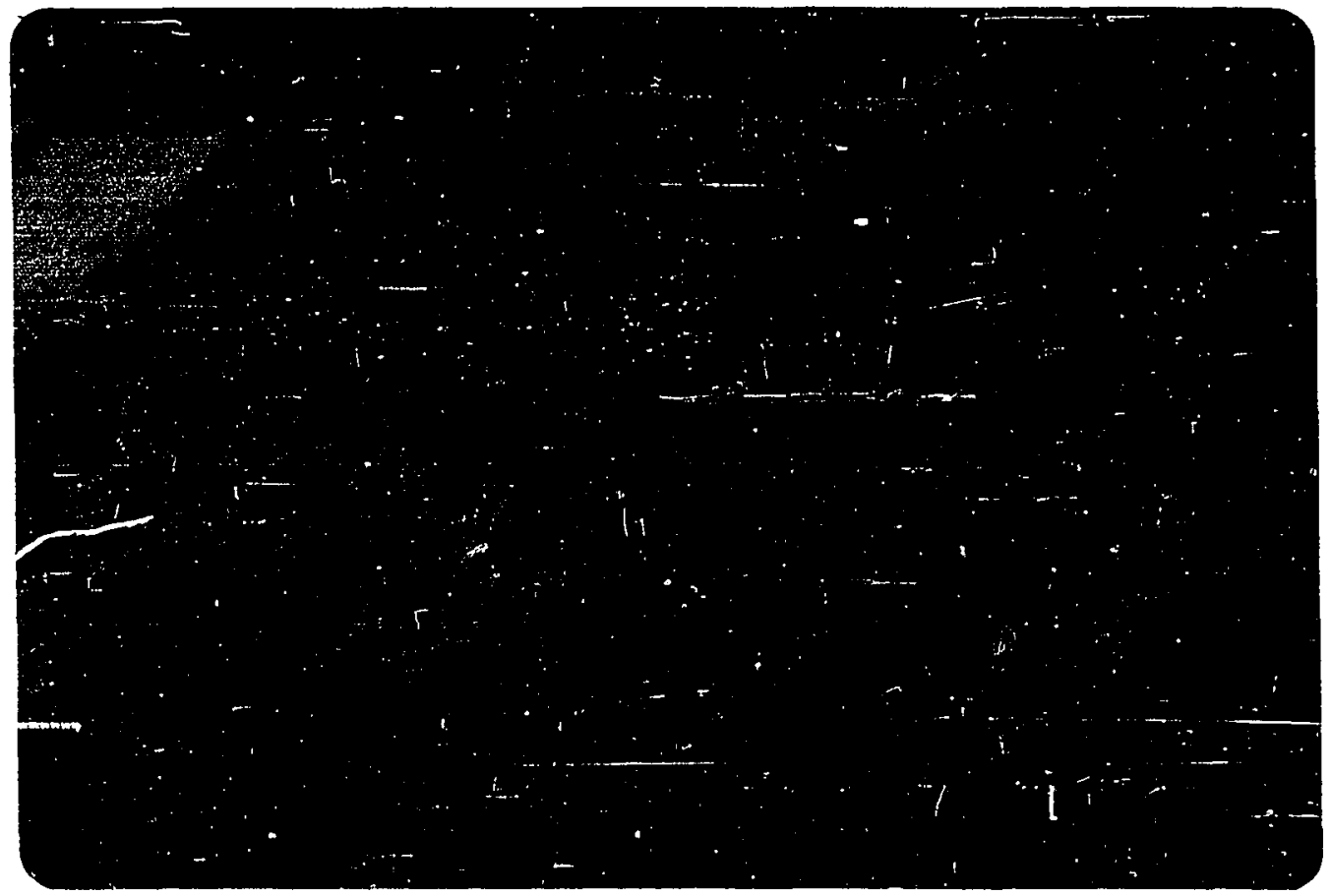

Figure 11. Peeled bitterroot spread in the sun and wind to dry. 
Native term: $k$ koogi ${ }^{11}$

Calochortus macrocarpus Doug1. (Liliaceae)

Common Name: Mariposa or Sego Lily

Description: A showy flower with three broad petals on an unbranched stem arising from a round starchy butb.

Habitat: $\quad$ Dry sagebrush plains.

Distribution: Extends from southcentral British Columbia to northeastern California and east of the Cascades to Idaho (Hitchcock and Cronquist 1974:686).

Indian Use: It tastes delicious and was preferred eaten fresh rather than cooked. Although it grows at the root camp, it does not appear to have been an important food resource.

The Surprise Valley Paiute (Kelly 1932:102) skinned and ate the bulb fresh (C. macrocarpus Doug1.), not having enough to dry and preserve.

Reportedly the Owens Valley Paiute (Steward 1933:245) utilized sigo, an unidentified tuberous mountain plant.

Native term: koogi $^{12}$ (Figure 12)

Zygadenus venenosus (Liliaceae)

Common Name: Death Camas

Description: A grass-like bulb plant with rather thick parallel-veined leaves and small cream-colored flowers which form a tight

${ }^{11}$ Koogi is a term which is applied simultaneously to Zygadenus venenosus, a poisonous plant. Murphey (1959:45) also applies the term "kogi a donup" to Zygadenus spp. and relates it to the Paiute.

${ }^{12}$ Koogi is a term which is applied simultaneously to Calochortus sp., an edible bulb. 


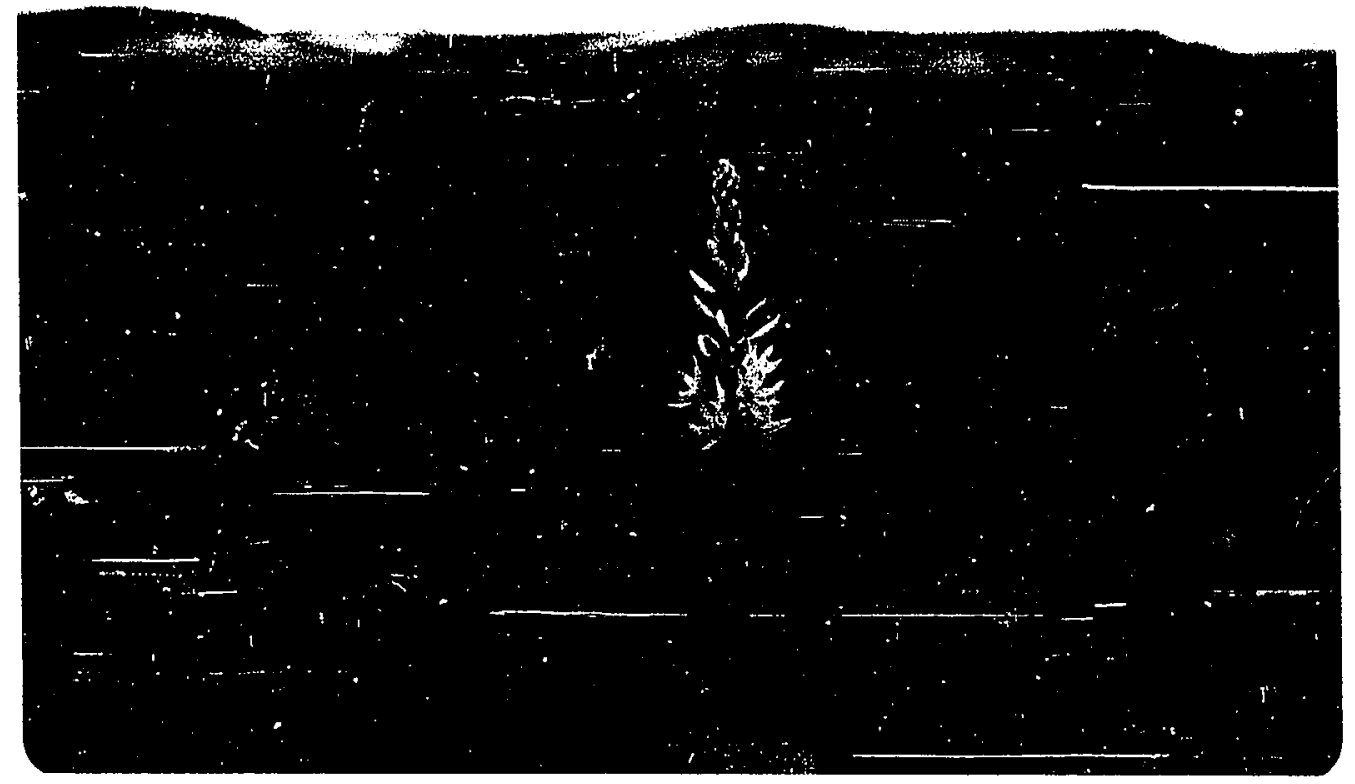

Figure 12. Koogi (Zygadenus venenosus) Death Camas growing amidst a field of blue camas (Comassia quamash). 
cluster.

Habitat: $\quad$ Exposed sagebrush hillsides; occurs occasionally in association with Camassia quamash.

Distribution: From southern British Columbia to Baja California. 2. venenosus gramineus extends east of the Cascades to north central Oregon (Hitchcock and Cronquist 1974:696).

Indian Use: The people are familiar with koogi and know the danger it represents. They avoid the poisonous plant, warning children of it, and are quick to point it out. ${ }^{13}$

Native term: $\quad$ kusiaki $i^{14}$

Balsamorhiza hookeri Nutt. ${ }^{15}$ (Compositae)

Common Name: Rock bälsamroot; Sunflower

Description: A low growing plant with numerous divided basal leaves, leafless stems and sunflower-1ike heads which range from two to three inches across.

Habitat: $\quad$ Dry rocky areas.

Distribution: East of Cascades from California to Colorado but absent from Oregon (Hitchcock and Cronquist 1974:496).

Indian Use: Favored for its good taste, the head of the sunflower was

${ }^{13}$ Stories abound of suicides as a result of eating 2 . venenosus or Delphinium sp. ("poisonous parsnip"), and reportedly with in their area of distribution, both plants account for the greatest loss of life to sheep and cattle than any other poisonous plant.

${ }^{14}$ The term kusiaki (Steward 1938:22) is applied by Shoshone to Helianthus sp.

${ }^{15}$ Whiting (1950:17) identified kusiaki as $B$. hooken Nutt.; but, this is questionable as Hitchcock and Cronquist (1974:496) maintain that this species is absent in Oregon. 
picked in August when it began to open, or a stick was used to hit the head, causing the seeds to drop onto a buckskin spread underneath the plant. The shells could be blown away with your breath. The seed was subsequently worked at with a mano and metate and ground into flour as other seeds. White the process of collecting and the method of preparation has remained alive through oral tradition, the species utilized could not be pointed out to me and, therefore, cannot be confirmed.

The Surprise Valley Paiute (Kelly 1932:103) ate the roots of bikwaida ( $B$. terebinthacea Nutt) raw (fresh or dried) and roasted them in the ground, subsequentiy pounding them.

\section{Native term: Kwinaapisa}

Scientific Name: Unknown

Common Name: Blackberry

Description: Medium sweet blackberries containing a seed.

Habitat: $\quad$ Grow near John Day, Oregon in rocky places along a creek or hillsides.

Distribution: Unknown

Indian Use: A desired berry that is eaten fresh or cooked.

Native term: kyyga (Figure 13)

AlZium acuminatum (LiTiaceae)

Alzium tolmiei Baker

Common Name: Wild orion

Description: Perennial herb with grass-like leaves and round bulbs with characteristic onion flavor and odor. Stem terminates in a flower head. A. tolmiei Baker has pink 

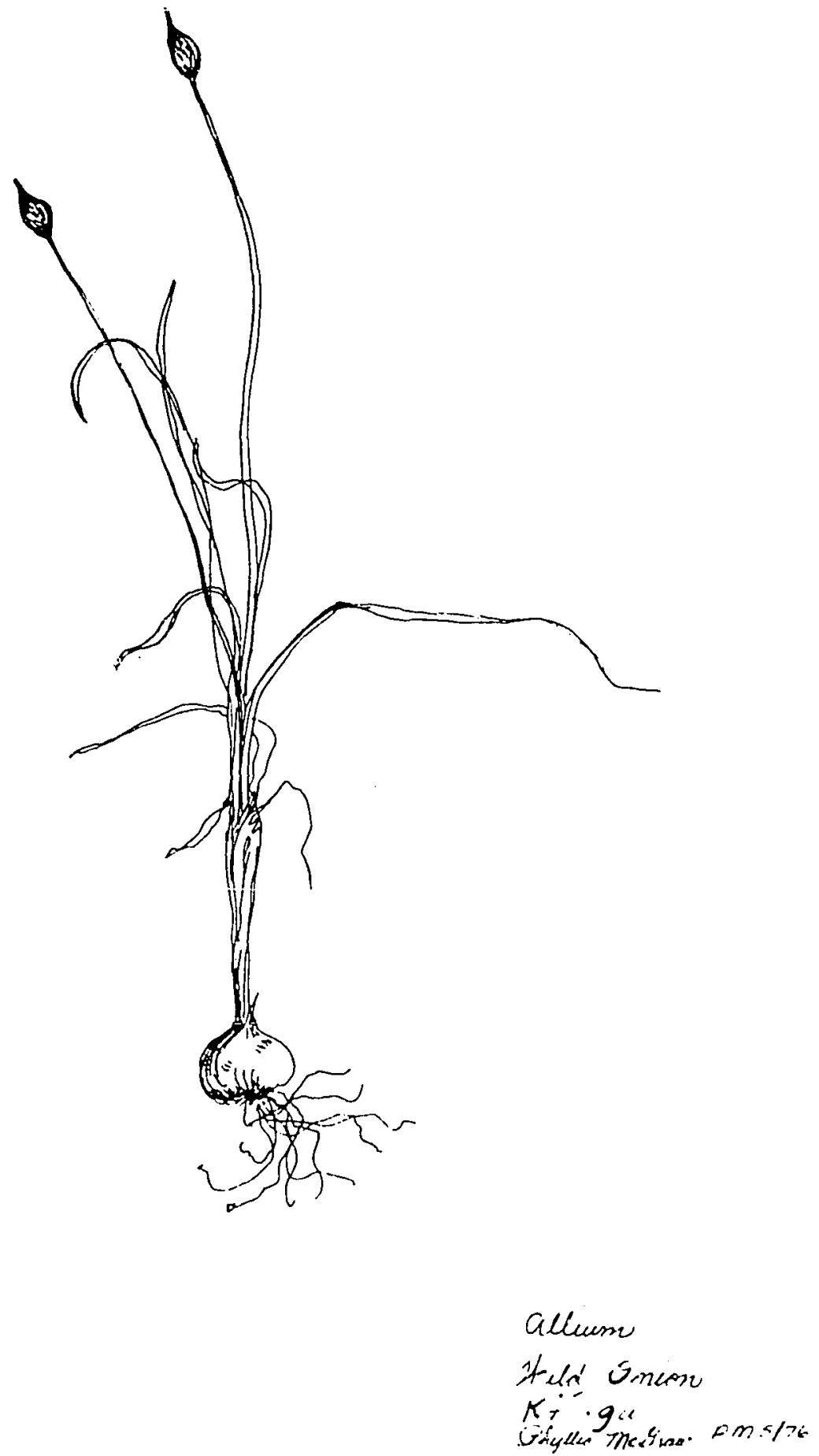

Figure 13. Kyyga (Alzium sp.) ild onion. 
flowers with symmetrical bulb; A. acuminatum has characteristic brown netted outer skin covering a small spherical butb.

Habitat: Rocky and coarse sandy soit in sunny exposed areas in association with Artemisia tridentata; Lomatium cous and Perideridia bolanderi.

Distribution: A. tolmiei Baker extends from southeastern washington to northeastern California and east to western Idaho (Hitchcock and Cronquist 1974:684). A. acuminatum is found east of the Cascades extending to California and Arizona (Hitchcock and ironguist 1974:682).

Indian Use. Considered a favorite, the leaves are boiled and eaten as greens, and the roots are peeled, boiled and eaten plain, as a seasoning or pickled in vinegar. The term "kyyga" is applied simultaneously to both species. ${ }^{16}$

Kelly (1932:102) recorded that the roots of mu' a (A. pleianthum Wats.) were gathered in quantity and cooked in earth ovens, with the leaves eaten as a relish; whereas the seeds and leaves of gu'ka ( $A$. acuminatum Hook were more desired than the roots. On the other hand, badis $^{i}$ (A. bisceptrum Wats.) and panizi (A. platycaule Wats.) were de.sired for their roots, seeds and greens. Kelly noted that it did not appear that wiid onions were dried, and my information seems to confirm that for the Harney Valley Paiute also.

Steward (1933) reported that a wild onion (unidentified) "was

${ }^{16}$ The term "sii" is applied to $A$. madidum Wats. 
gathered by men; harvested from wet places in the spring and eaten green with salt" (Steward 1933:244).

Native term: namugot

Pentstemon sp. ${ }^{17}$ (Scrophulariaceae)

Common Name: Pentstemon

Description: Perennial herb with white flowers borne in a cluster. Plant is about 10 inches high.

Habitat: $\quad$ Dry sagebrush plains.

Distribution: No available.

Indian Use: The leaves are collected in the spring, boiled, and used to treat poison oak.

Native term: paazigo (Figure 14)

Camassia quamash ${ }^{18}$ (Liliaceae)

Common Name: BTue camas; sweet camas

Description: An herbaceous perennial which blooms in late spring with blue flowers and grass-1ike leaves with parallel veins. Stems are one or two feet tall with large glutinous bulbs present.

Habitat: Meadows, near creek beds and in non-alkaline areas.

Distribution: From British Columbia south to California, extending east and west of the Cascades (Hitchcock and Cronquist 1974:

${ }^{17} \mathrm{~A}$ sample could not be located for identification.

${ }^{18}$ The blue flower distinguishes the edible species from the white flowering poisonous plant zgadenus venenosus. At the root camp the two species grow side by side and care is exercised not to confuse the two, as the bulbs and ieaves are similar in size and shape. 


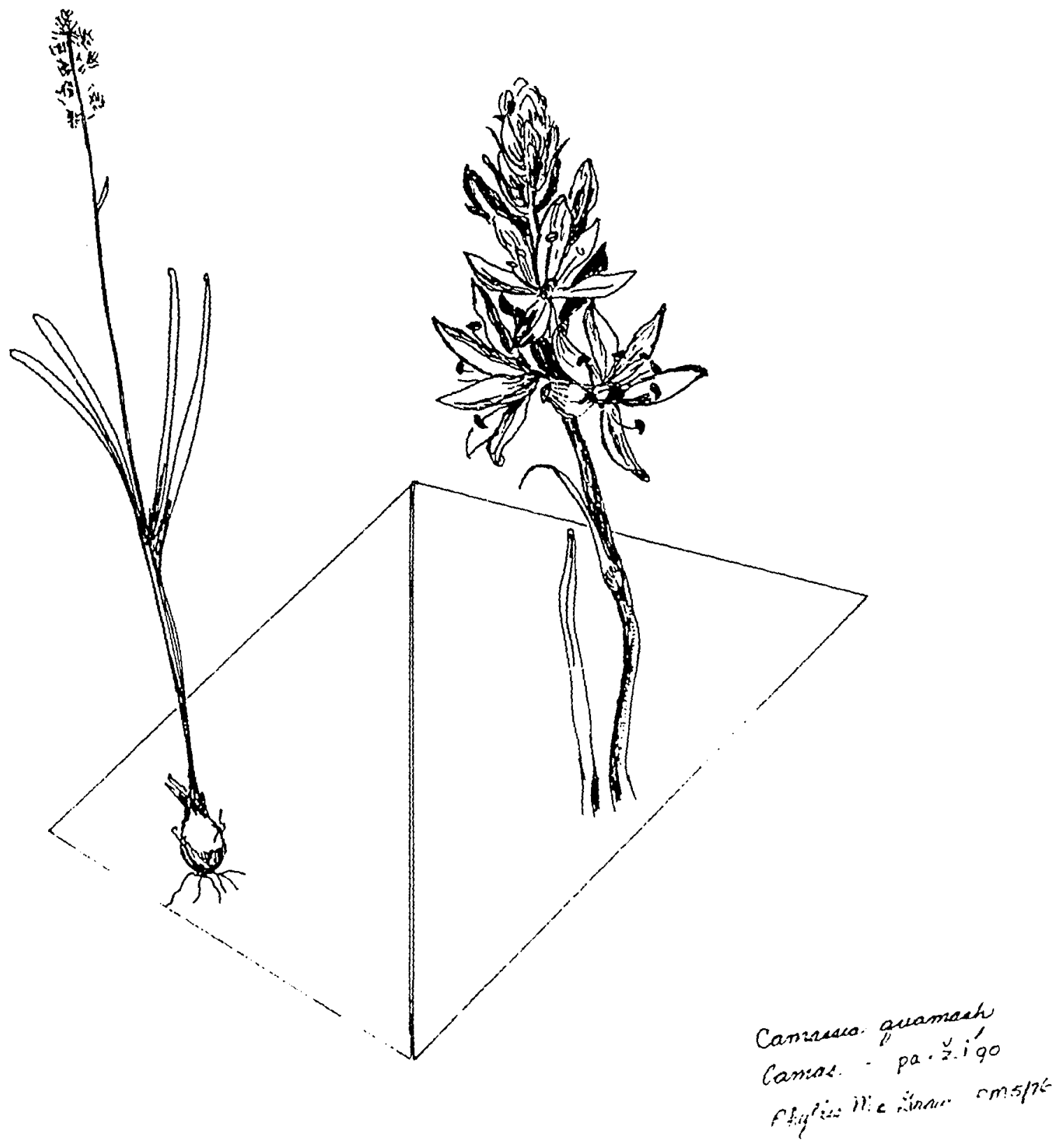

Figure 14. Pazigo (Camassia quanash) blue camas. 
$688)$.

Indian Use: The Indians formerly dug camas where it grew profusely around Harney in meadows such as Cow Creek drainage (Figure 15). It was one of the most highly prized roots. Harvested after it blooms, in the seed pod stage, it was dug with a digging stick, peeled, the tops removed; whereupon it was either eaten fresh, cooked, or dried to be used later.

The traditional method of preparing it was by pit roasting, as follows: First a large pit or earth oven about three feet deep was dug and lined with rocks. Next, women gathered lots of dry sagebrush and built a huge fire in the pit. After the fire was reduced to hot coals, they heaped grass over the coals and sprinkled it with water. Camas bulbs were spread on top of the grass and covered with more grass and then sprinkled with more water. Then they buried the whole thing with lots of dirt, letting the camas cook and steam for four days and four nights. Men could not sleep with their wives and had to avoid sexual contact with them during this time. One male source told me the reason for this was to insure that the camas wouldn't burn. Following the roasting, the camas turned black in color and a huge feast was held so that all could induige in the tasty food which was eaten directly or else dried. Reportedly it kept well after having been couked, and resembled sweet potatoes in flavor. In recent times it has been prepared in a cast iron dutch oven surrounded with hot coals and cooked until done. Though still a favorite, the highly nutritious and valued camas butb is no longer dug. Camas favors fertile soils, and these are the same localities which offered optimum conditions for white agricultural 


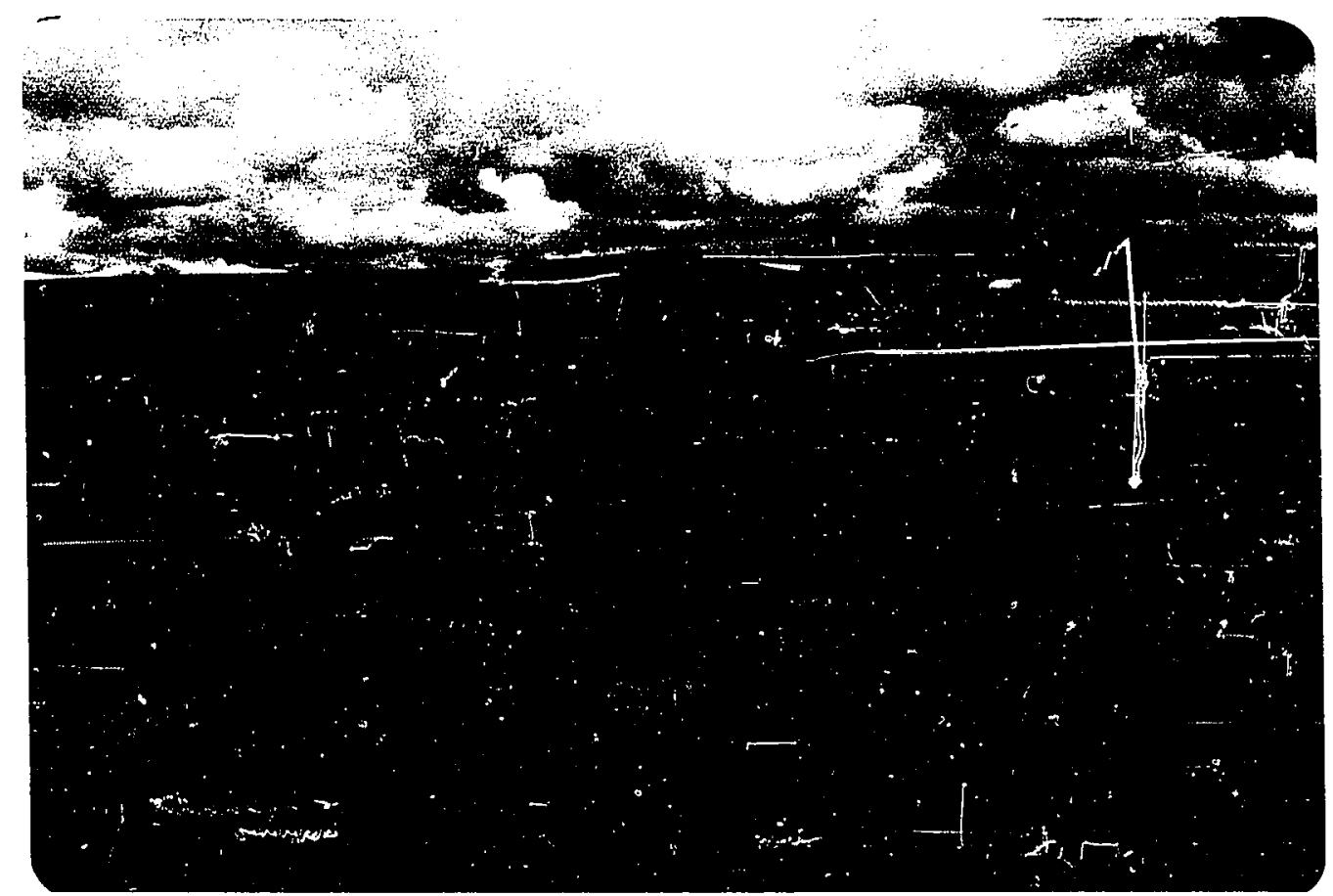

Figure 15. Paazigo (Comassia quamash) blue camas growing in meadows near Harney. 
settlement. The Indians would like to collect it, but they are prohibited from entering private lands to dig. The reason given by ranchers is that they leave holes behind ${ }^{19}$ which cattle step into, causing them to fall.

Kelly (1932:102) reported that camas was plentiful in some areas for the Surprise Valley Paiute and that it was cooked similarly in earth ovens overnight.

Thought the distribution of Comassia quamash does not extend as far south as the Owens Valley, Steward (1938) in later studies expressed the belief that pasigo was "perhaps Calochortus". This, in spite of the significunt fact that he recorded that the Lemhi Shoshoni "procured (it) only at Camas Prairie" (Steward 1938:189).

Nutritionally (Extension Circular 809:8), one cup provides 1/10 of the Recommended Dietary Allowance of vitamin C (which is subsequently destroyed in the drying or long cooking process), 1/2 to 1/3 RDA of iron, and a considerable protein content which is comparable to the amount in potatoes, peas, beans and cereals.

Native term: pakwana

Mentha amensis (Labiatae)

Common Name: Mint, wild mint, field mint

Description: An aromatic herb strongly smelling of mint containing branching square stems with sharply toothed leaves and pink, white or violet flowers.

${ }^{19}$ The Indians that I observed digging roots carefully covered their holes with a kick or two of their feet (this practice was unsolicited and recorded on film by me in May 1976 and 1977). 
Habitat: Wet marshy ground.

Distribution: Widely distributed through the western United States.

Indian Use: The leaves are boiled into a refreshing drink. Both the stems and leaves are collected, dried and utilized. Occasionally fresh

green leaves are steeped in hot water and served with sugar.

Native term: poziidapy

Trifolium macrocephaZum (Leguminosae)

Common Name: Big-headed clover

Description: Herbaceous plant with palmate leaves containing more than three leaflets and pink flowers $22-28 \mathrm{~mm}$.

Habitat: $\quad$ Rocky places in sagebrush desert to ponderosa pine woodlands.

Distribution: East of the Cascades, extending from southcentral Washington to Nevada and east to western Idaho (Hitchcock and Cronquist 1974:275).

Indian Use: This species was recalled as a favorite sweet when they were children; they used to suck the nectar from the blossom.

Steward $(1933: 243)$ reported that the seeds of $T$. tridentatum Lind1. and T. involucratum Ort. were utilized among tie Owens Valley Paiute as well as the entire plant when it was young and tender as greens without cooking.

Native term: puihibamo ${ }^{20}$

Nicotiana attenuata Torr. (Solanaceae)

${ }^{20}$ puihi: translates to "green". 
Common Name: Tobacco

Description: An annual dark green narcotic herb growing one to two feet high with toothed leaves containing a tubular white flower.

Habitat: $\quad$ Dry open often sandy places.

Distribution: East of the Cascades and throughout the Great Basin.

Indian Use: It was smoked and also used medicinaliy, mashed and rubbed on sores and wounds, and on snake bites. Stewart (1941:376) records that the Burns Indians burned areas for tobacco; however, I found nothing to substantiate this.

Within the Owens Valley (Steward 1933:319) the tobacco yield was increased by burning, pruning and irrigation during drought. He also reported that the leaves were collected in late summer, dried, ground, moistened and stored in bal1s 12 to $16 \mathrm{~cm}$. in diameter.

According to Kelly (1932:181) puhi-pamo (also called wisi-pamo) leaves were dried, pounded and stored in sacks with deer fat for flavor. Medicinally, smoke was blown into the ear for deafness and earache; tea was used for stomachache; and a tobacco-balsam mixture was designated for colds.

Native term: pokopisa ${ }^{2 I}$

Eibes aureum Pursh (Grossulariaceae)

Common Name: Golden currant

Description: Spineless shrubs with alternate, palmately veined leaves, members.

${ }^{2}$ Pokopisa is alternately applied to Prunus virginiana by some 
bright yellow flowers and golden currants which ripen in JuTy.

Habitat: $\quad$ Stream banks, springs, gullies, from sagebrush desert to ponderosa pine forest.

Distribution: Eastern slope of Cascades from north central Washington to California (Hitchcock and Cronquist 1973:202).

Indian Use: They continue to pick the wild currants along the Silvies River bank as in years past. They formerly travelled by wagon to this area which was considered "out in the country". As with $R$. cereum the berries are eaten fresh, dried, or made into syrup or jam.

Native term: saiby

Scirpus validus Vaht (Cyperaceae)

Common Name: Butrush, Tule

Description: A perennial herb with hollow or pithy erect stem with spikelet flowers.

Habitat: $\quad$ Wet ground in swamps, marshs, ponds, and lake edges;

alkali tolerant.

Distribution: Widespread in temperate North America and throughout the Great Basin (Hitchcock and Cronquist 1974:602).

Indian Use: The roots of tender young tule were gathered, washed and the white meat eaten uncooked. In addition, tule stems were gathered for cordage, and tule mats were woven for shelters which resisted rain and snow.

Ke11y reported (1932:103-104) that the roots were not dried, and Steward (1938:29) reported that in addition to the lower stems and roots being eaten throughout the Great Basin, the Owens Valley Paiute (Steward 
1933:2:5-246) wove tule baskets for storage.

Native term: sawabi

Artemisia tridentata Nutt. (Compositae)

Common Name: Basin sagebrush

Description: An herbaceous plant ranging to large woody shrubs; silvery gray wedge shaped leaves are three-lobed and have the characteristic aromatic sage odor.

Habitat: $\quad$ Dry plains and hills; intolerant of alkali. Prefers mildly basic and relatively moist soils (Taylor and Va7um 1974:17).

Distribution: From British Columbia to Baja California, east of the Cascades (Hi íchicock and Cronquist 1974:488).

Indiani Use: Among the Harney Valley Paiute sagebrush was used primarily as an important source of fiber, fuel and for medicinal purposes. As a fiber two-ply twine of inner sagebrush bark was woven by men into nets. The outer and inner bark was twisted into cordage for tying things. Sagebrush bark blankets which were used as bedding or capes were manufactured as were sandals and coarsely woven bags for food storage. The bark was also shredded, rubbed soft and inserted in moccasins to keep the feet warm. In addition, sagebrush overshoes were manufactured to wear over moccasins to keep the feet dry. When pounded, the outer bark formed a good tinder and sagebrush was considered an important source of fuel in treeless areas and is still the preferred fuel for outdoor camp cooking. Also, reportedly, torches were made of bundles of sagebrush bark attached to a juniper handle which were used 
to 1 ight caves. ${ }^{22}$ Medicinally it was used for colds, coughs, sore throats and flue and they still resort to using it today when all else fails. It was used during the Hong Kong flu epidemic in 1957. Clean green leaves are collected from the top of the plant and brewed into a tea and drunk. Though reportedly it tastes "awful", it loosens the chest up. It was also used as a compress or poultice on wounds. In addition, the leaves were used as a covering over berries, seeds and roots preserved in caches. Stewart $(1941: 521,389,387,366)$ reports that they also used sagebrush bark to line storage pits, to make burden bacgs, door mats, and that sagebrush bark rope was utilized in the corral during the communar antelope hunt.

Kelly (1932:137-197) confirms the same fiber, fuel and medicinal uses for the Surprise Valley Paiute and also reports that skirts were manufactured.

Among the Owens Valley Paiute (Steward 1933:243) the bitter seeds were relatively unimportant. They were used generally when mixed with other seeds in times of food shortage. They were roasted in the conventional manner, ground into flour and eaten with water (Steward 1933: 243).

Furthermore, among the Walker River Paiutes (Johnson 1975) it was used in a very special way, medicinally:

... when we have a headache, why he (grandfather) put water in this basket and het get sagebrush in there and you put it on top of our head and he go like that. Our headache would go away.

Johnson $1975: 13$

${ }^{22}$ Stewart $(1941: 381)$ reported there was no evidence for bark bundle torches being utilized. 
Native term: siabi

Rosa sp. (Rosaceae)

Common Name: Wild rose hips

Description: Prickly shrub with fleshy red berries or hips.

Habitat: Roadside waste areas and stream banks.

Distribution: Unknown

Indian Use: The hips are picked when red and the leaves are gone. They are boiled, mashed, and strained through a cloth. The juice is mixed with browned flour to make a sauce or gravy, or mixed with sugar to make jam. The hips are also strung as beads.

Native term: sigupi

Chrysothamnus nauseosus (Compositae)

Common Name: Rabbit brush

Description: Broad shrubs with narrow linear leaves containing brilliant golden yellow flowers which bloom in mid or late sunmer to fall.

Habitat: $\quad$ Dry open places from lowland to occasional mid elevation in mountains, in association with Artemisia tridentata.

Distribution: Chiefly east of the Cascades in the West.

Indian Use: The Burns Indians collected small lumps of a secretion from the top of the root in April when the sap was up and chewed it as a gum. I tested it and found it quite unpalatable and bitter.

Kelly (1932:104) reported that the root at the surface level was chewed until gummy and contained no taste but sounded good when chewed. Furthermore, the Surprise Valley Paiute (Kelly 1932:197) used it medicinally by drinking or bathing in an infusion of crushed leaves for a 
cold remedy.

Steward (1938:23) reported that more than one species of Chrysothamnus was used widely throughout the Great Basin for chewing gum and that the bark of the lower stem and roots was the substance that was chewed.

Native term: suunuu (Whiting 1950:19)

Atriplex sp. (Chenopodiaceae)

Common Name: Saltbrush

Description: Often spiny herb or shrub.

Habitat: Alkaline sagebrush desert.

Distribution: A. argentea Nutt and $A$. trucata extend from southeastern Oregon to California, east to Montana, Colorado and New Mexico (Hitchcock and Cronquist 1973:96).

Indian Use: According to Whiting (1950:19), the Burns Indians gathered these seeds at the same time as they gathered waada or a little later, presumabiy from the same iocation as waada. ${ }^{23}$

Steward (1933:244) reports that the seeds were eaten in Owens Valley.

Native term: Syybi $i^{24}$

Salix sp. (Salicaceae); Comus stolonifera ${ }^{25}$ (Cornaceae)

${ }^{2}{ }^{3}$ From my observation $A$. tmuncata was prevalent at the northeastern border of Malheur Lake, and this may have been the species collected; however, it was not acknowledged to me that they utilized any saltbrush, nor were they familiar with the term suunuu.

${ }^{24}$ According to Catherine Fowler (personal communication), syybi is an ancient Uto-Aztecan term which designates "weft" or "weaving."

${ }^{25}$ The Indians made no distinction between salix sp. and Cornus stolonifera, but simultaneously apply the term syybi to both genera. 
Common Name: Willow; Red-osier dogwood

Description: Salix sp. is a shrub or tree with narrow, pinnately veined leaves.

Habitat: Moist to wet ground, often along streambanks.

Distribution: Throughout the West from sea level to above timberline (Hitchcock and Cronquist 1974:66).

Description: Cornus stolonifera is a shrub or tree, ranging from 2-6 meters tall, with simple pinnately veined leaves, and white petals.

Habitat: $\quad$ Moist ground and a Tong streambanks

Distribution: In the West extending to Idaho and Nevada (Hitchcock and Cronquist 1974:339).

Indian Use: Willows and the red-osier dogwood are the necessary raw materials used in the manufacture of most of the household goods traditional1y. Omer Stewart $(1941: 386,387,382,371,404,377,379)$ recorded that willow was used in manufacturing willow baskets using willow sapwood for the coil and twine weft; twined willow water jug covered with pine pitch with stopper of juniper bark or grass; twined and coiled cups; willow bundles used to drive fish; willow whistles; willows as the frame for the domed wickiup and sweat house.

In addition, seed beaters, cooking vessels, bowls, trays, baskets in which to collect seeds, burden baksets, fish traps, and cradleboards were also manufactured of willow and red-osier dogwood.

Today willow and red-osier dogwood are still collected along the banks of the Silvies River by a few older members for the manufacture of cradle boards (huupy). They prefer "red willows" (Cornus stolonifera) because they are stronger. The willow is gathered from September 
through February before the new buds appear, making peeling easier and adding to the strength of the split strands. Formerly willows were buried in damp ground to preserve their moisture after picking. Willows are checked for quality by tieing a knot in one and observing the flexibility to be sure it won't break. Also, the core is checked in the center for size. A small core indicates the willow is good; the larger the core, the more possibility of it weakening the willow after it has been split. The straight willow twigs are peeled while still fresh, and the bark is scraped either by knife or as was traditionally done with a crescent-shaped obsidian blade. The syybi is then sorted, and tied in bundles according to size and length. Using the larger straight peeled willows for the frame and warp (Figure 16), either smaller willows or coiled flexible willow sapwood which has been split three ways along the core with the teeth and both hands and soaked in water is used for the twined weft. The woven willow platform is then covered with buckskin which has been soaked in cowbrain and tanned by hand. A hood or sunshade woven from slender willows is attached to shade the infant, and the finishing touches are added, including cowry shel1s and beads which dangle from the hood to amuse the infant, and beaded embroidery in a diamond or zigzag pattern to indicate a girl's huupy and a series of diagonal lines for a boy.

In September, 1978, one woman was observed making a three-rod coiled willow basket.

It appears that among the Surprise Valley Paiute (Kelly 1932) and the Owens Valley Paiute (Steward 1938) willow provided the basis for 


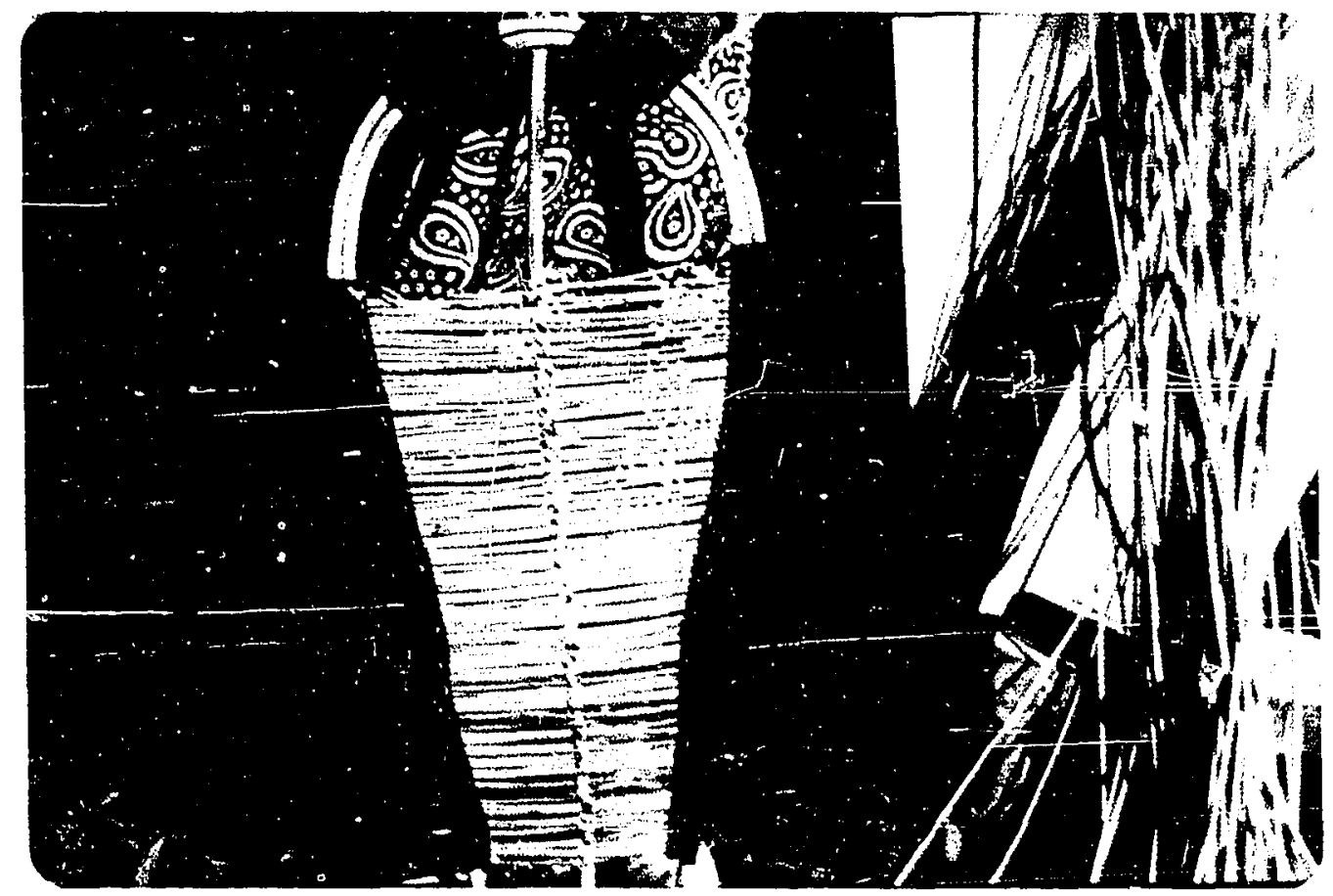

Figure 16. Peeled willows form the frame and warp of a cradleboard. 
the manufacture of most household goods also. ${ }^{26}$

Native term: tokabonoma

Vaccinium membranaceum (Ericaceae)

Common Name: Blue or black huckleberry; Mounta in bilberry; Blueberry

Description: A branching deciduous shrub growing up to $2 \mathrm{~m}$. tall, elliptical leaves with sharply saw-toothed edges; turn orange-red in the fall. The flowers are creamy-pink and the shiny berries are large (7-9 mm.), sweet, spherical, and reddish-purple or purple.

Habitat: Mountain slopes and dry sites in coniferous forests.

Distribution: In the Cascades from southern British Columbia to California and east to Idaho and Montana (Hitchcock and Cronquist 1973:350).

Indian Use: They are picked in Tate summer and preserved by covering the berries with their own leaves (Figure 17) replacing the leaves as they dry out. They keep exceptionally well for a week or more using this method. The berries are subsequently frozen, cooked, or canned to be made later into pies, jam and syrup. In the past the Harney Valley Paiute traveied to Dixie Butte in the Greenhorn Mountains, to the Strawberry Mountains, and to Canyon City to pick huckleberries. It was recalled that the Indians used to come to High Rock in the Mount Hood National Forest by horseback long ago to pick them; in recent timies

${ }^{26}$ However, a select few of th- Owens Valley Paiute (Steward 1938: 269) manufactured clay pottery characterized by sma11, flat-bottom vessels; furthermore, large, round-bottom vessels of superior work manship have been recovered from archeological sites in Owens Valley. 


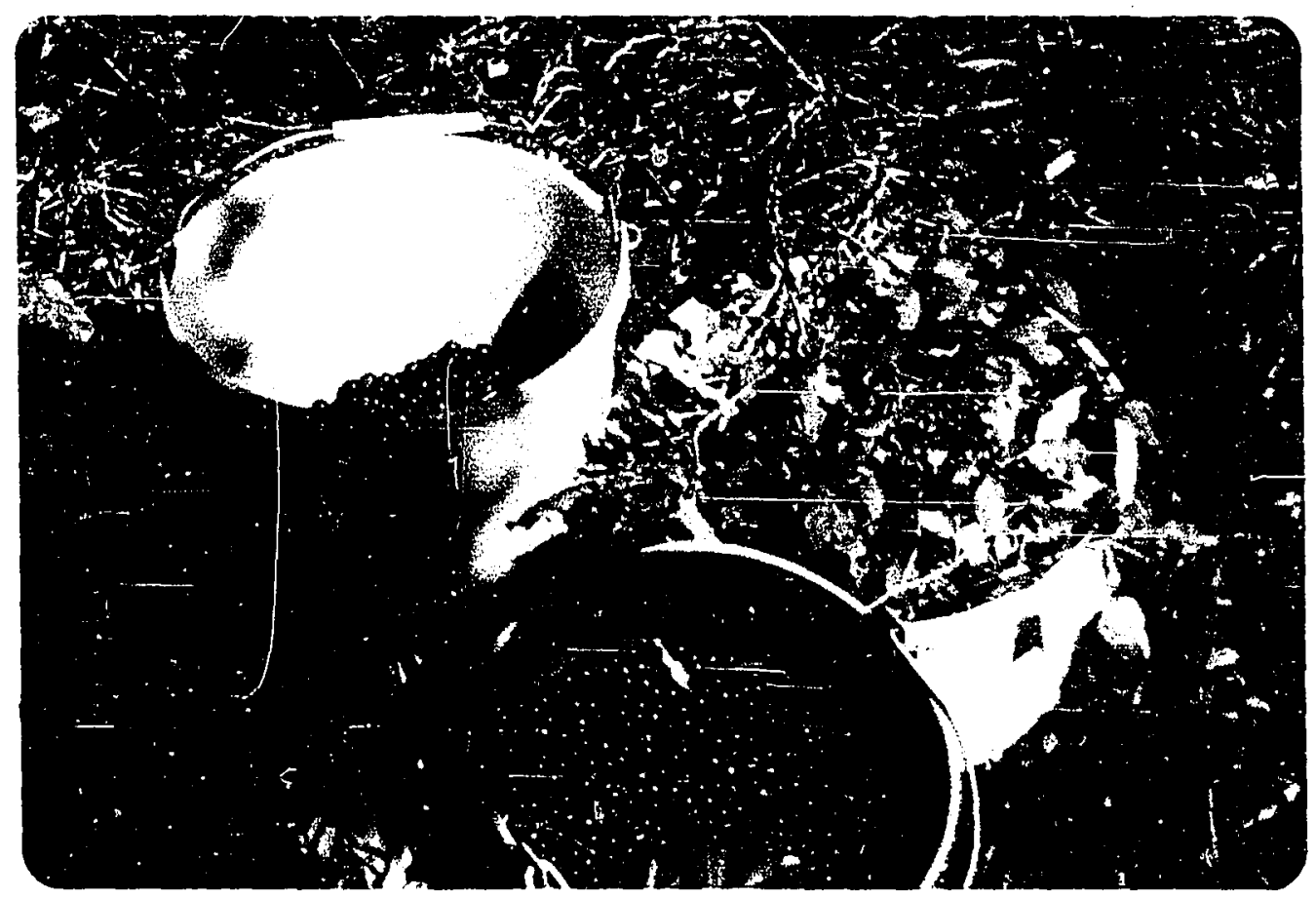

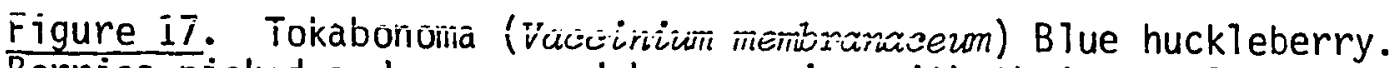
Berries picked and preserved by covering with their own leaves. 
they travel as far north as Mt. Adams by car to collect them. Reportedly, one woman and her husband used to pick 80 to 100 gallons of berries in a week, keeping only enough for their own use, and selling the rest to people generally considered "too lazy to pick their own," from Redmond, Warm Springs and Burns.

Native term: tooisabui (Figure 18) ${ }^{27}$

Prunus virginiana (Rosaceae)

Common Name: Chokecherry

Description: Deciduous trees or shrubs which grow 2 to $4 \mathrm{~m}$. Sweet but astringent fruits ripen in September and are red or black.

Habitat: Moist shaded areas along stream banks and canyons.

Distribution: This species appeared in a number of locations, including Crow Camp Hills, ${ }^{28}$ Silvies River, Poison Creek, and Rattlesnake Creek near Harney, and is believed to be $P$. virginiana demissa. However, according to Hitchcock and Cronquist (1973:221) the distribution of this species occurs only west of the Cascades from British Columbia to northwestern Oregon.

Indian Use: The black cherries are preferred. The fruits are picked fromi stems, washed, and mashed with a grinding stone on a metate (Figure 19), thereby crushing the pits wherein the flavor lies. ${ }^{29}$ Cakes are members.

27 "Pokopisa" is alternately applied to Prunus virginiana by some

${ }^{28} \mathrm{~A}$ preferred area for collecting them in the past.

${ }^{29}$ A though the pits contain dangerous levels of cyanide (Kirk 


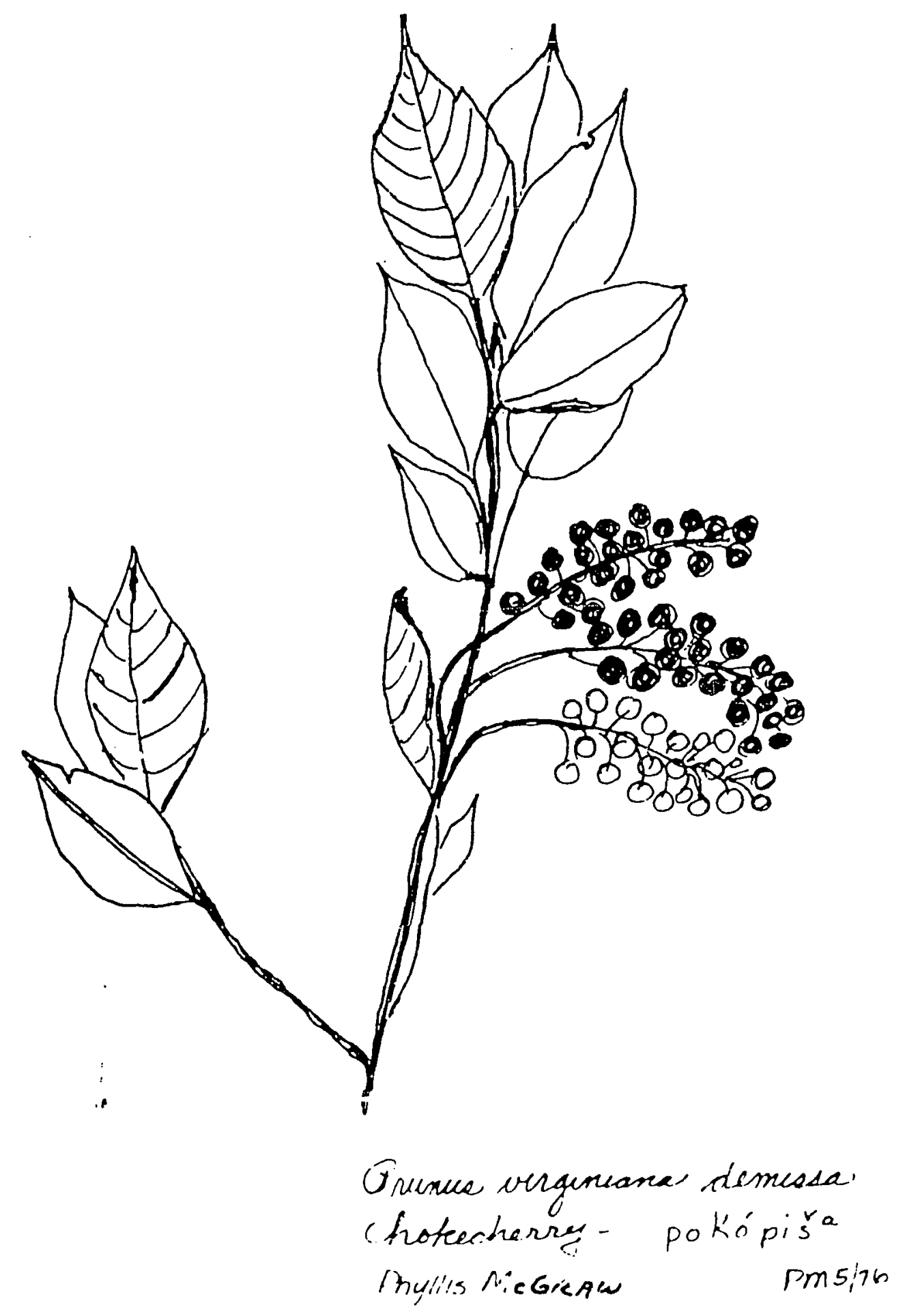

Figure 18. Tooisabui/pokopisa (Prunus virginiana) chokecherry. 


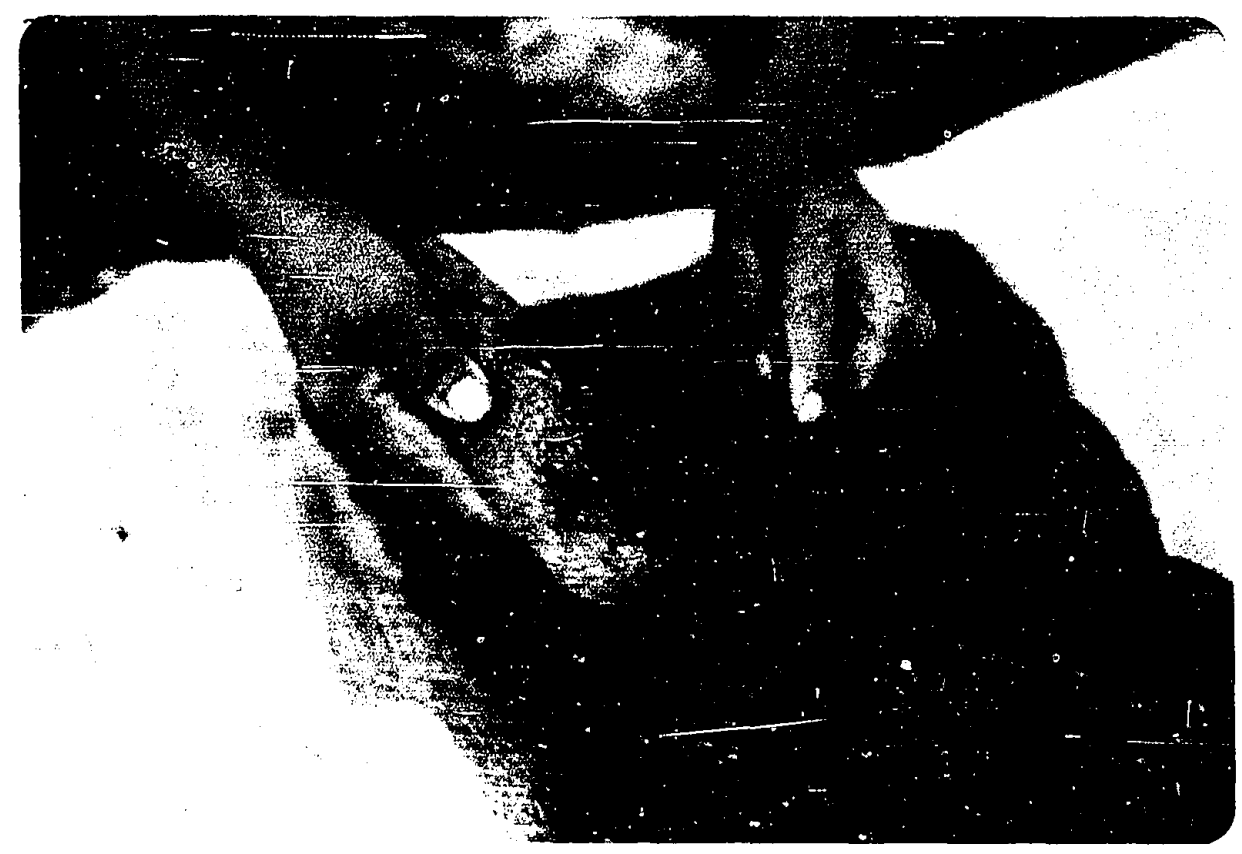

Figure 19. Tooisabui (Pmunus virginiana) chokecherry. Fruits are crushed with a grinding stone on a metati to form cakes. 
formed by the hands and dried in the sun and wind. In the past they were stored in buckskin bags, but today they are stored on a shelf until ready for use. To use they are first soaked overnight in water, then boiled and the crushed seeds are strained out as "the bones aren't good." The juice is then thickened with a little flour and vanilla to make pudding, or by the addition of sugar, syrup or jelly is made. They did acknowledge that if the fruits are eaten without cooking and straining the pits, it will cause one to become $i 11$.

Kelly (1932:99) reported that occasionally chokecherries and waada seeds were combined and eaten, that a beverage was made by poliring hot water over the fruits, and that a tea was made from chokecherry stems. Reportedly (Steward 1938:28), Prunus sp. was more abundant and located in the lower elevations in the northern Great Basin.

Native term: toiby Typha Zatifózia L. (Typhaceae)

Common Name: Cat-tai1; Butrush

Description: Throughout the United States, Canada and Mexico (Hitchcock and Cronquist 1974:676).

Indian Use: Young shoots were collected in the spring and peeled, eaten raw or boiled as were the roots which were broken open, and the white meat eaten raw. Plants gathered in early summer were utijized for their seeds and pollen which were ground on a metate to make cakes arid mush. In addition, the leaves were used as matting materials and in building shelters. Reportedly, the snow doesn't adhere to them but

1970:95L, the poison is released during the cooking process, 
slides off, leaving the shelter dry.

Kelly (1932:99) reported that the root was more important as food for the Surprise Valley Paiute than the seeds.

Steward $(1933: 265)$ recorded that the Owens Valley Paiute manufactured "grass houses" of Typha sp. along with tule (Scirpus sp.) and giant rye grass (Elymus condensatus Presl.).

Native term: tuupi

Cercocarpus Zedifolius (Rosaceae)

Common Name: Mounta in mahogany; curl-leaf mahogany

Description: An evergreen shrub or tree, 6-18 ft. high, eliptical leaves with flowers of five small yellowish sepals (no petals). The spindle-shaped fruit bears a long terminal feathery style.

Habitat: $\quad$ Desert foothil1s, canyons, mountains, often in rocky ground.

Distribution: From Washington to California east of the Cascades extending to Montana and Colorado (Hitchcock and Cronquist $1974: 209)$.

Indian Use: Mountain mahogany was used traditionally by the Harney Valley Paiute for digging sticks for removing roots. The digging stick (podo) was a straightened piece of hardwood which had been sharpened to a point at one end with a stcne knife and was subsequently hardened in the fire. The fire-hardened hardwood digging stick of yesterday has given way today to a straightened forged iron bar with a slight curve approximately three feet in length pointed on each end (Figure 20). One end contains a juniper handle or a shortened wocden axe handle about 


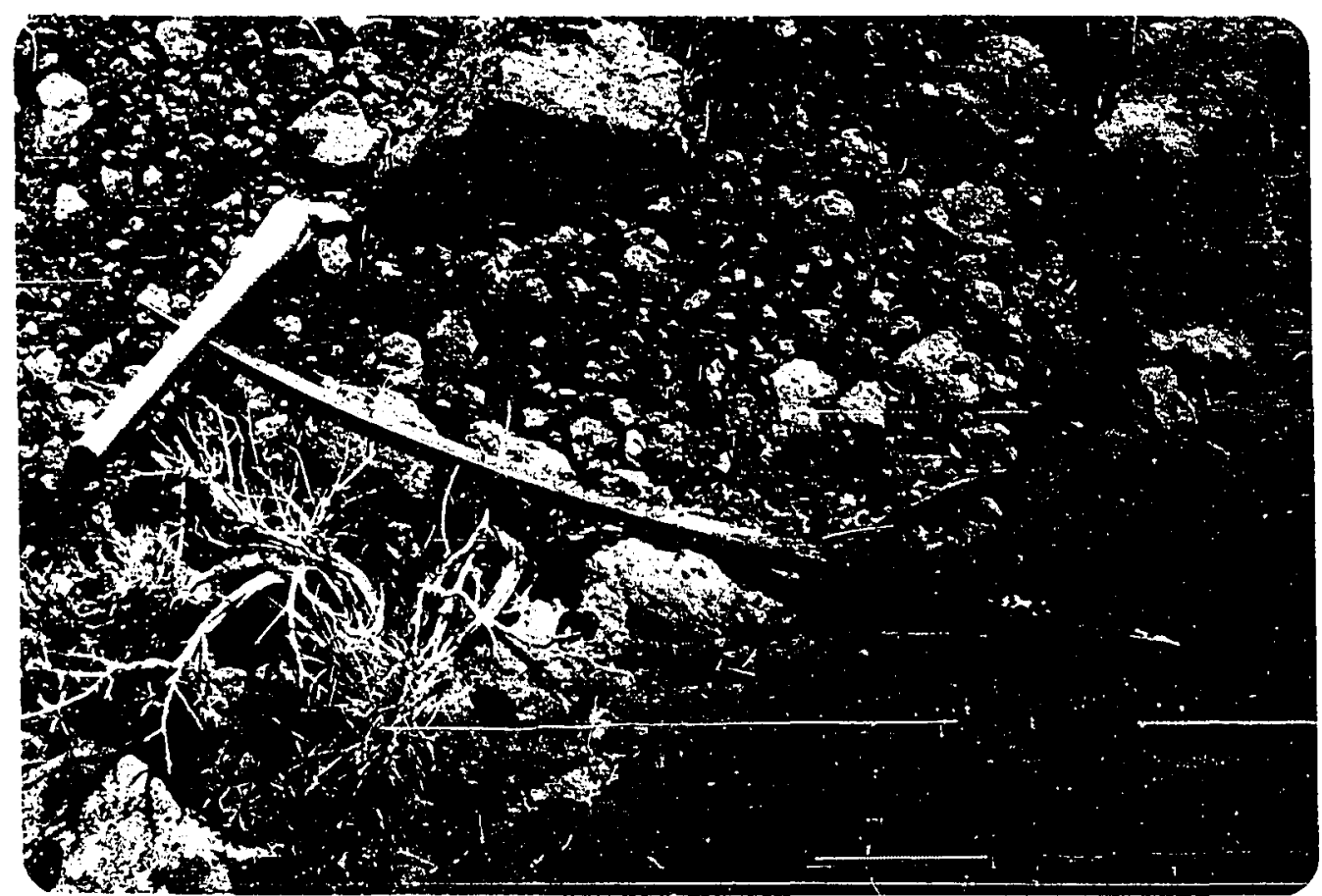

Figure 20. Digging stick. 
$10 "$ in length; as an alternative, a short handled pickax purchased from a surplus store is used or a pitch fork. One woman chastised her granddaughter for using the digging stick as a crowbar. She pointed out that it should be grasped one hand on the handle (right hand) and one hand about half way down the stick; then the implement is thrust back and forth through the rocks to loosen the roots of the plant; prying down with the right hand, the plant is lifted with the left.

Aithough the implement used by the Surprise Valley Paiute was similar, the technique used may have been different as Kelity (1932) pointed out that "the butt rested against the body, one hand on it, and the other part way down the shaft. From demonstrations, the technique was one of pushing rather than of thrusting" (Kelly 1932:101).

The Owens Valley Paiute (Steward 1933:244) used a similar implement which was manufactured of either mountain mahogany or buckbrush (Ceanothus cuneatus Hook).

Native term: tuyu

Prunus subcurdata

Common Name: Pacific wild plum; Klamath plum; Western plum Description: Stout spiny crooked branched shrub or small tree, with finely toothed oval leaves, white to pink flowers which develop into a dark-red fruit.

Habitat: Stream banks to dry rocky slopes.

Distribution: Willamette Valley to southern California (Hitchcock and Cronquist 1974:221).

Indian Use: For more than sixty years the Burns Indians have trave1- 
led to John Day, Ft. Bidwe11, and Paisley, Oregon and to New Pine Creek, California, where orchards of wild plums grow. The fruit is harvested in late summer, the seeds removed, and the plums are either dried in the sun or canned to be used later. They are cooked with the juice strained out for flavoring candy, jam, plum butter. For sauce or gravy they are thickened with sugar and browned flour.

Kelly reported (1932:99) that they were gathered in the Warner Mountains in an open-twine burden basket, were pitted but not crushed, and then dried. Reportedly they were "pretty strong" before sugar was available.

Native term: tyba (Figure 21$)^{30}$

Pinus ponderosa Doug1.; Pinus monophyzza (Pinaceae)

Common Name: Pine; Pinyon pine ${ }^{31}$

Description: $P$. ponderosa Dougl. is a large evergreen up to $70 \mathrm{~m}$. ta11 with needles in threes; mature trees have reddish bark.

Habitat: $\quad P$. ponderosa extends from British Columbia to Baja California and east of the Cascades (Hitchcock and Cronquist 1974:62).

Description: $\quad P$. monophyzza is an evergreen with spreading growth and dense covering of pine cones; needles are borne singly.

Habitat: $\quad$ P. monophyzla appears in dry inland areas, in pure stands, and generally between 5000 feet and 9000 feet

${ }^{30}$ The term tyba is applied simultaneously to both species. ${ }^{31}$ Pinyon pine applies onty to Pinus monophylza. 


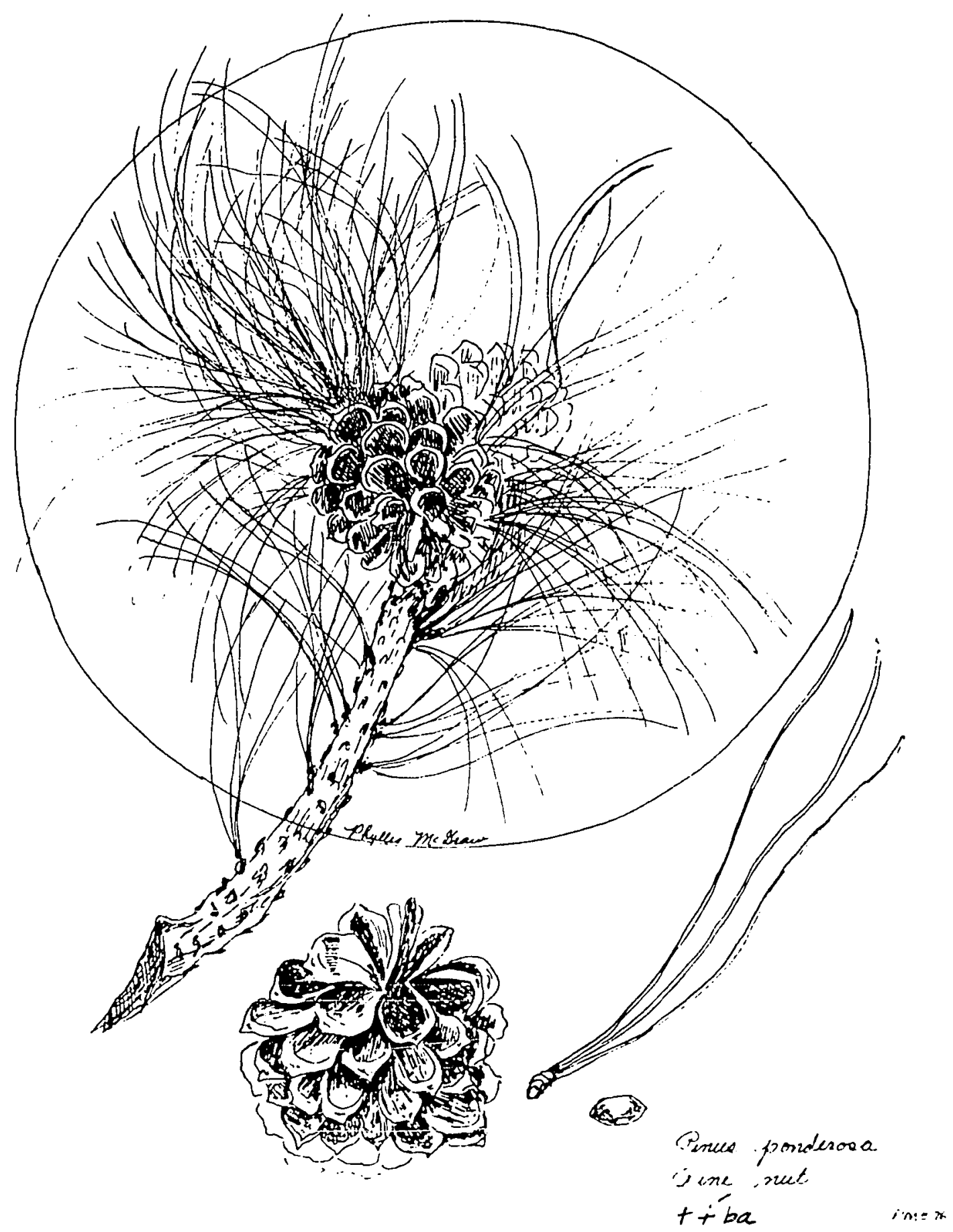

Figure 21. Tyba (Pinus monophyzza) pinyon pine. 
elevation.

Distribution: While P. monophyzZa appears extensively in the southwestern United States and the Great Basin, its distribution does not extend as far north as southeastern Oregon.

Indian Use: The Harney Valley Paiute gathered pine cones in the fall in the $P$. ponderosa forests north of the Valley towards Seneca. Presumably pine nuts were of minor importance for these people. Pine cones were gathered from the base of trees and from creek beds after chipmunks and squirrels cut off the cones and dropped them. They were then taken back to camp where a large fire was prepared. The cones were covered with hot ashes, and the pine nuts cracked and fell out. They were then winnowed, ground on metates and worked at in the same manner as other seeds. According to Stewart $(1941: 428)$, Blind Jim reported that the Kuyui-eaters from Pyramid Lake, Nevada, brought pinon nuts to Burns in the old days to trade. $P$. ponderosa was also utilized for its pitch which was smeared on the outside of cooking baskets and jugs to waterproof them. In addition, Stewart $(1941: 375)$ reported that white pine pitch (which he assumed to be $P$. monticola Dougl.) was used as sugar. ${ }^{32}$ Reportedly, as recently as twenty years ago, the Indians utilized the cambium of $P$. ponderosa as a sweetener. To arrive at the one cell thick layer of inner bark, they selected a liiature tree and removed a section of outer bark approximately three feet long and twenty inches wide.

${ }^{32}$ It was reported to me that nakabowi (tamarack - possibly a Larch or Pine) sap was eaten as sugar, and resembled molasses in flavor. 
Pine nuts considered of minor importance to the Surprise Valley Paiute (Kelly 1932:99), were known from Pyramid Lake, Nevada.

According to Steward (1932:241) pine nuts were of prime importance to the Owens Valley Paiute with individuals gathering $30-40$ bushels in the fal1, and good crops alternating with bad. Furthermore, pinenut areas were owned by districts and were frequently the cause of conflict between otherwise peaceful districts. The harvest, a community effort, was conducted by a head man. Long beating poles, bags, baskets, mats and sacks were among the implements used, with everyone getting in the act. The cones were knocked from the trees with a hooked pole and then placed in a fire pit and roasted or partially charred so thai the nuts were loosened. They were also roasted in a loose-twined basketry tray with hot coals; then shelled, winnowed and eaten directly, ground into meal on a metate, or stored in buckskin sacks of baskets in caches until such time as they were mixed with water to form soup, mush, etc. They were also mixed with other seeds, such as giant wild rye grass.

Native term: waada (Figure 22)

Szaeda intermedia ${ }^{33}$ (Chenopodiaceae)

Common Name: Seepweed; Seablite

Description: A perennial herb up to $6 \mathrm{dm}$. in height; lower leaves range from $1020 \mathrm{~mm}$. long, with the tiny black seeds about $1 \mathrm{~mm}$. broad.

${ }^{33}$ The sample collected was determined by PSU Botany Dept. to be this species; however, the sample on file in the herbarium at Malheur National Wildlife Refuge reputedly from this area was determined to be Suaeda nigra. 


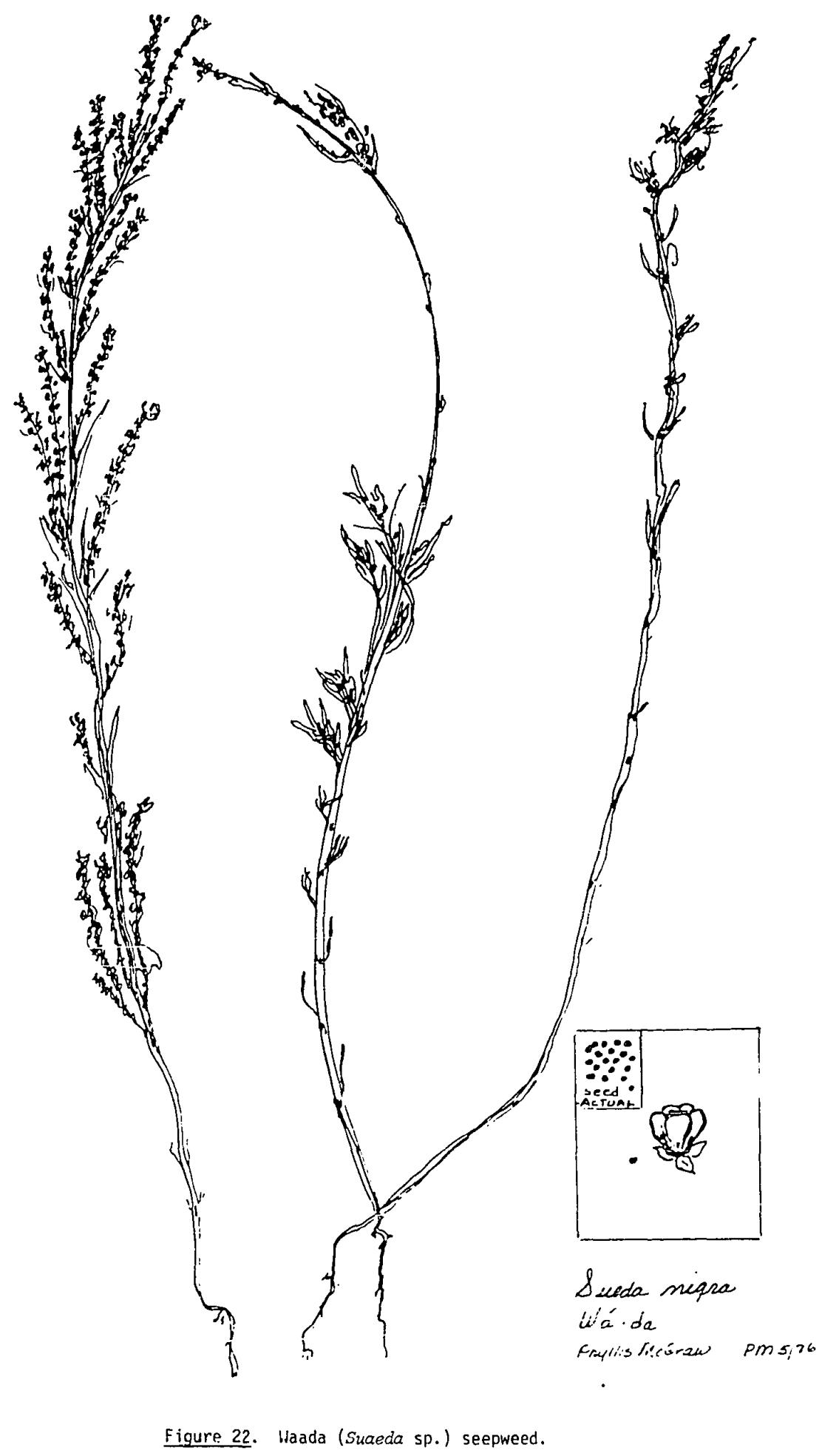


Habitat: $\quad$ Sunny exposed saline or alkaline soil, often where marshy, in association with grasses and other chenopods, i.e., Sarcobatus vermiculatus, Bassia hyssopifolia, and Atriplex trmeata.

Distribution: East of Cascades from British Columbia to California and east to Saskatchewan, Minnesota and Texas (Hitchcock and Cronquist 1973:101).

Indian Use: It is recorded by oral history that waada seeds were collected in large quantities. Large numbers of people congregated each year by late August on the northeastern shore of MaTheur Lake to gather the "tiny black seeds" (Figure 23) and to join in the festivities, including games and dances. Reportedly they camped here in sagebrush shelters before canvas tents came into use about 1872. The "tiny black seeds" were harvested by first spreading buckskin or canvas on the ground and then beating the plant with sticks. The seeds were then parched in a finely woven fan-shaped willow tray which was covered with pine pitch on the outside. A hot coal from a sagebrush fire was stirred by hand around the seeds, causing them to crackle and jump. As the seeds cooked, they mashed them with their hand against the side of the basket. After cooling, they were winnowed in the wind by working the seeds to one side with a rotary motion, separating the chaff from the seeds. The seed was made as clean as possible before grinding on a flat stone with a mano, thereby forming a meal which: was subsequently stored in hide sacks. The medl was prepared by adciing a little water and boiling in a willow basket by the addition of hot stones, forming a gruel or mush, taking care to stir it constantly so as not to burn the basket. 


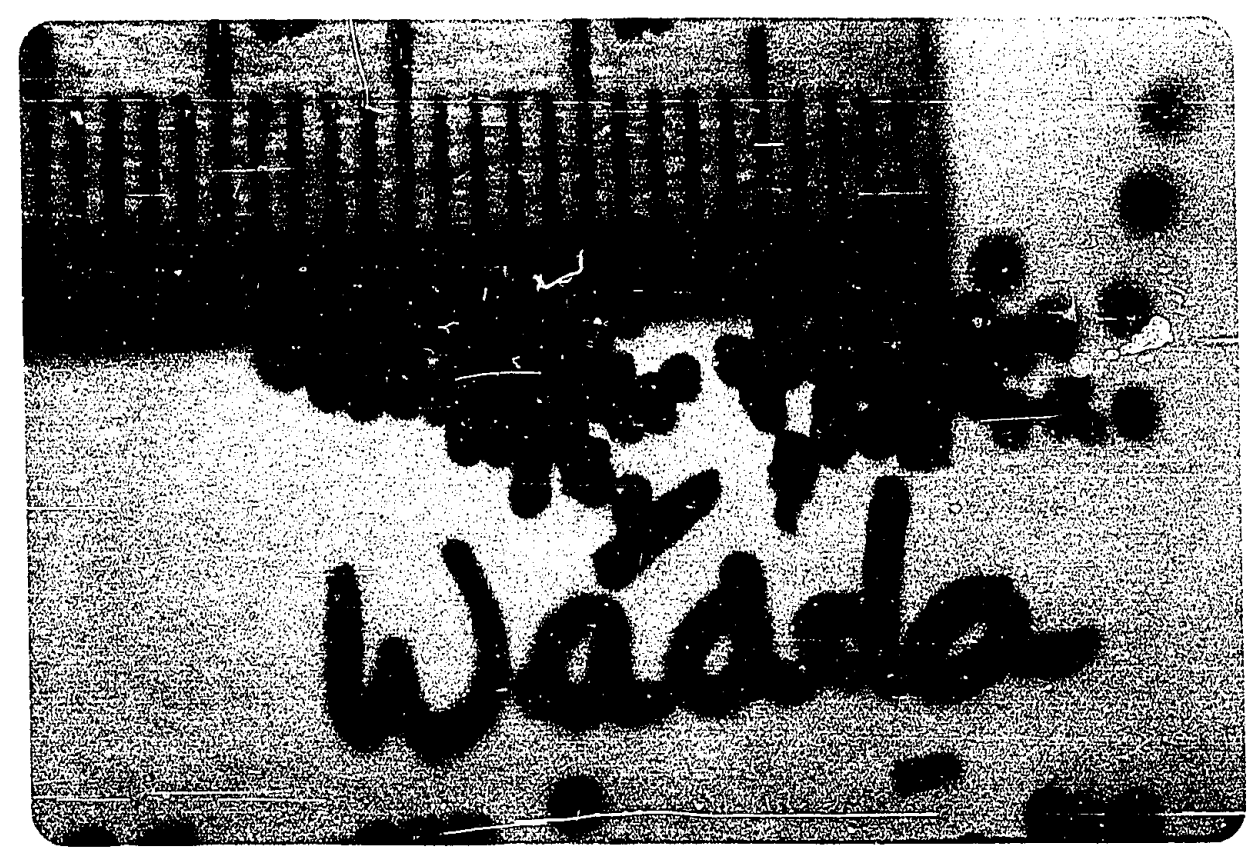

Figure 23. Waada (Suaeda intermedia) seepweed, "tiny black seeds."



Figure 24. Field of waada growing near Mailheur Lake. 
in addition, seed beads were made out of the "tiny black seeds."

In September, 1975, I observed several fields of waada (Figure 24) growing near Matheur Lake. One area appeared to be $20 \times 30 \mathrm{~m}$ and another appeared $50 \times 100 \mathrm{~m} .{ }^{34}$ I collected a quantity of seed by beating the tops with a stick (the plants did not appear to be harmed by this process). Fifty-four and one-tenth gm of waada debris were collected from a one meter square area, and after being parched and winnowed the total seed was reduced to $16.95 \mathrm{gm}$ or $31.3 \%$ of the total debris collected.

This represents only a portion of the former total area of distribution and a point in time 100 years after the fact. It is my impression that the plants mature at different rates and may have been harvested two or three times in a season. The area observed of 5600 square meters may have yielded up to $285 \mathrm{~kg}$. Given that waada formerly had a greater distribution in this area prior to grazing rights, perhaps up to ten times that observed, I assert that the net result of 2850 $\mathrm{kg}$ would not have contributed substantially to the diet of even several hundred people, except as may have been used for an occasional treat. At any rate, it appears there was not sufficient quantities of this to have been used as a basic staple. If this is any indication of the relative importance of a particular food item for which people were named (as commonly appears throughout the Great Basin), the item named may not necessarily refer to a basic food staple, but only to the fact that the food item grew in the area with which they were associated.

${ }^{34}$ These fields were open to grazing but cattle avoided the waada in favor of grasses. However, in a fenced area the cattle had stripped the plants, and the grasses had infringed upon the waada population, generally taking over. 
Native term: waapi

Juniperus occidentalis Hook (Cupressaceae)

Common Name: Juniper

Description: Evergreen tree ranging from 4-10 $\mathrm{m}$. with scale-like leaves and characteristically aromatic blue to bluegreen berry-iike cones.

Habitat: Desert foothills and lower mountains in arid areas; commonly occurs in conjunction with the pinon pine in Utah, Nevada, and California, and is found in pure stands in the Northern Great Basin.

Distribution: Abundant east of the Cascades from ceniral washington to Southern California and east to Blue Mountains, Oregon, and southwestern Idaho and Nevada (Hitchcock and Cronquist $1974: 58)$.

Indian Use: Juniper berries, crushed and pounded, were mixed with deer liver. Medicinally, berries were boiled in water and brewed (skimming the pitch from the surface); it was then drunk or the vapors were breathed for colds, coughs, and flu. They also brewed leaves with water and used them as a compress or poultice on wounds. In addition, juniper provided firewood and was usefur in house construction as the supporting poles. Such poles are still used today to suppori canvas windbreaks and tents. ${ }^{35}$ It was also used in the manufacture of bows. ${ }^{36}$

\footnotetext{
${ }^{35}$ It was significant to me that they are able to recall over a twenty year period the circumstances surrounding specific cut poles at the root camp, i.e., the person who cut them and where he hid them.

${ }^{36}$ One bow, manufactured in a day's time, measured $38^{\prime \prime}$ Tong and $1 \frac{1}{2} "$
} 
According to Steward $(1933: 264)$ Indians in the Sierra were observed using stripped juniper bark for "tent making."

Native term: wata; i'ape ${ }^{37}$

Chenopodium album L.; Chenopodium Sp. (Chenopodiaceae)

Common Name: Goosefoot, Pigweed

Description: An herbaceous annual with ovate alternate leaves; seeds form in clusters, and flowers are greenish.

Habitat: $\quad$ C. album abounds in wastelands on alkaline or saline soi soi1; C. fremontii Wats, is found from sagebrush desert to lower mountainous forest.

Distribution: From British Columbia, east of the Cascades to Baja California (Hitchcock and Cronquist 1974:98,99).

Indian Use: Though Whiting (1950:19) recorded that wata and $i$ 'ape were seeds collected by the Burns Indians, no one recognized the native term nor did they recall the use of such plants.

Steward (1938:23) noted that the seeds grew in irrigated land for the Owens Valley Paiute, and were gathered, ground into flour and utilized as other seeds.

Native term: wiapui

Sheperdia argenta ${ }^{38}$

wide. When compared to lshi's bow on display at the Lowie Museum, $U$ of $C$, Berkeley, it was not unlike it, except for being unbacked and containing a nylon bowstring.

${ }^{37}$ According to whiting 1950:19.

${ }^{38}$ Identification uncertain. 
Common Name: Buckberry; SiTver Buffalo berry

Description: Shrub to small tree, 2-6 m. with thorny branches, silvery leaves, and reddish-yellow fruit.

Habitat: Alkaline areas, mostly along streams, low meadows and stream valleys.

Distribution: British Columbia to southern California, east of Cascades (Hitchcock and Cronquist 1973:302). In the past the Harney Valley Paiute collected them from an alkaline area south of the Steens Mountains and from the foothills of the Pueblo Mountains. More recently they have been imported from McDermitt, Nevada.

Indian Use: They are harvested in late summer by breaking a branch from a small tree, spreading it on canvas and hitting it with a stick, causing the berries to fall off. Subsequently they are dried on a screen and turned frequent1y. To prepare they are first soaked overnight in water, boiled, crushed, and strained. A gravy is made from the juice by the addition of some thickening.

Reportediy, the Surprise Valley Paiute (Kelly 1932:100) covered the berries with rye grass, set it on fire and stirred well to cook the berries before drying them. Before use they had to be "washed hard" to remove the accumulated charcoal.

\section{Native term: wihowi}

Apocynum cannabinum (Apocynaceae)

Common Name: Dogbane; Indian hemp; Milkweed

Description: Perennial herb with erect stalks which contain a fine 
soft silky fiber with greenish-white to pink flowers and milky juice.

Habitat: Moist rich soil of river bottoms. ${ }^{39}$

Distribution: Throughout the United States.

Indian Use: Stewart $(1941: 388,389,428)$ reported that wihowi bark was utilized by the Indians in making nets and that it made excellent fibers for cordage, rope and string. ${ }^{40}$

Native term: winida

Fritillaria pudica (1iliaceae)

Common Name: Yellow fritillary; yellow bel1

Description: A perennial herb consisting of a starchy buib with a cluster of offset butblets.

Habitat: $\quad$ Sandy soil in exposed sunny grassland or sagebrush desert. Distribution: East of the Cascades, from British Columbia to Nevada (Hitchcock and Cronquist 1974:691).

Indian Use: Collected at the bud stage, this plant is prepared and used in the same manner as cuka (Lomatium cous).

Native term: wodaa kwasiba ${ }^{41}$

Achillea millefolizm iompositae)

Common Name: Yarrow

Description: Strorigly scented perrenial herb with pinnately dissected

${ }^{39} \mathrm{I}$ observed it growing along the Donner and Blitzen River on the MaTheur Nationaì Wildịfe Refuge, Harney County, Oregon.

${ }^{40}$ The Indians did not acknowitedge to me that they ever used it.

41Translates to "Squirrel tai1." 
leaves resembiing a "bushy squirrel's tail." White

flowers form a dense terminal flat-topped head.

Habitat: Common in dry pine forest and in sage along the edges of

forests. Elevation ranges from 2500 feet in California

to 11,000 feet in Colorado (Kirk 1970:141).

Distribution: Throughout the Western United States.

Indian Use: Medicinally the leaves were washed, ground, mashed and made soft and were then applied and spread on wounds, sores, on sprains and to reduce swellings. 42

Native term: yapa; yampa, payapa; suiyapa ${ }^{43}$ (Figure 25)

Perideridia bozanderi (Umbelliferae)

Common Name: Wild carrot; Indian carrot

Description: A lacy appearing perennial with leaves divided into long narrow segments and white flowers borne in dense ba11like clusters.

Habitat: $\quad$ Sagebrush hills, ridges and washes at elevations approximately 4800 feet in mo st areas, particularly near creek beds, in association with Allizm sp., Camassia quamash, and Lomatium cous.

Distribution: Throughout eastern Oregon and Idaho to Utah, Nevada and Sierran California (Hitchcock and Cronquist 1974:336).

\footnotetext{
${ }^{42}$ It was used recently by Sally Dave (dcd. 1976) who applied it to the facial sores of a girl. "Though the girl looked funny, it took care of her," reportedly.

${ }^{43}$ There appears to be considerable free variation in the term.
} 


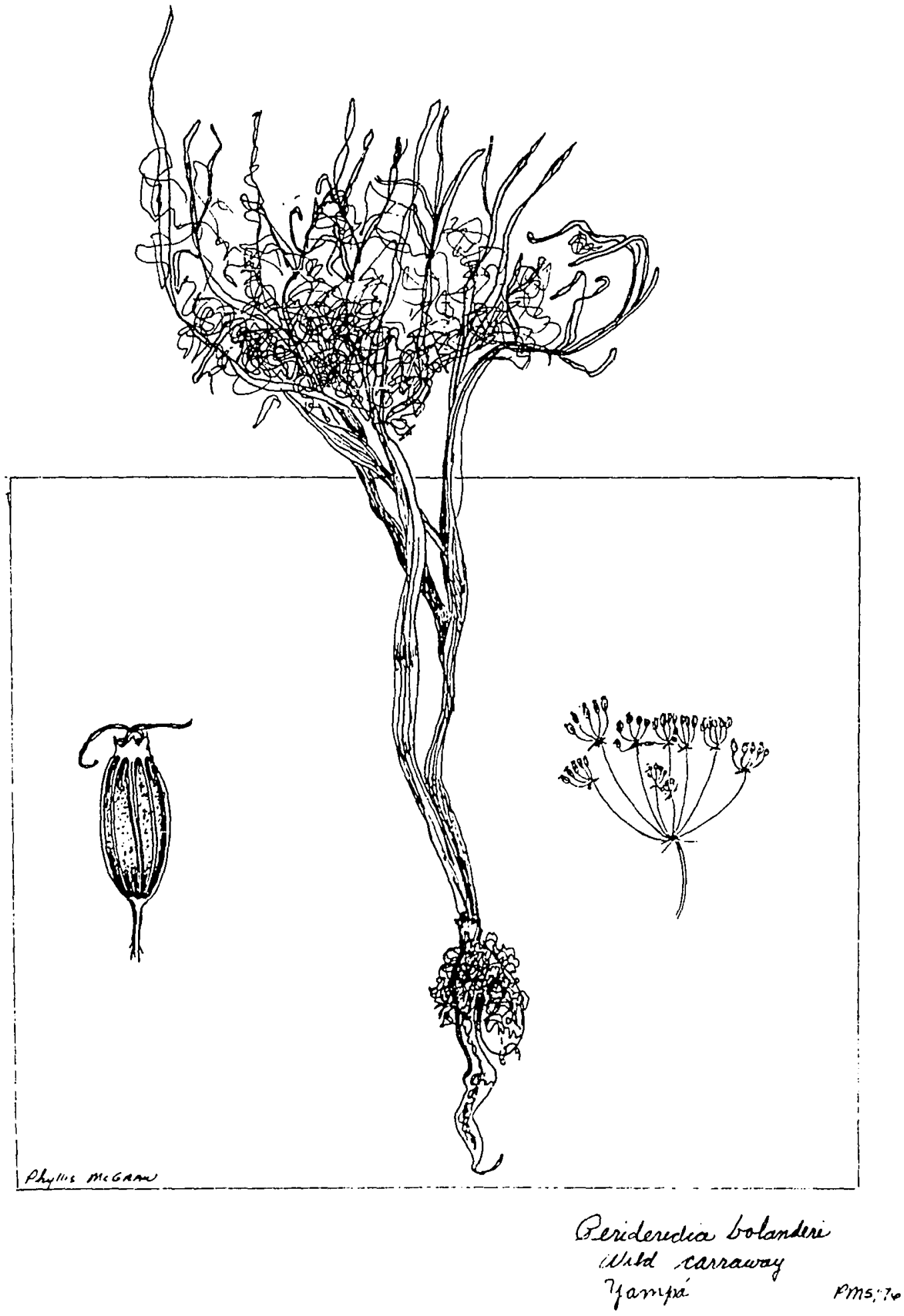

Figure 25. Yapa/yampa/payapa/suiyana (Perideridia bolanderi) wild carrot. 
Indian Use: Yampa is a favorite root (Figure 26), and is dug when the plant is in bloom. ${ }^{44}$ The elengate starchy bulb is delicious after having been peeled by slipping the skin with the fingers, washed in creek water and eaten fresh or boiled. It is also dried in the sun and wind, and stored in sacks, or is flash frozen to be cooked later. Traditionally, it was dried and ground into flour for baking, or while it was still moist the pulp was formed into patties similar to the "threefinger" or "palm" cakes of cuka. Whiting (1950:17) recorded that epos (Yapa, Carrom oreganzm Wat.s. $)^{45}$ were dug.

It appears to have been a fairly important food source among the Surprise Valley Paiute (Kelly 1932:101).

While the distribution of Perideridia sp. did not extend as far south as the territory of the Owens Valley Paiute, Steward (1938:23) recorded that Corm gairdneri (yamp) was a prominent food source for a number of Shoshone and Northern Paiute throughout northern Nevada and in Idaho.

Native term: Unknown

DeIphinizm sp. (Ranunculaceae)

Common Name: Delphinium; Larkspur; Poisonous parsnip

Description: Perennial herb with large fibrous to tuberous fleshy root and purple sepals with white petals which bloom in

\footnotetext{
${ }^{44}$ The root of yampa goes deep, and due to a weakening of the stem just above the root, it frequently breaks off just short of being removed from the ground; this may be regarded as a natural conservation measure.

${ }^{45}$ This species is currently known as Perideridia oregana Wats., and corresponds with pamahayapa.
} 


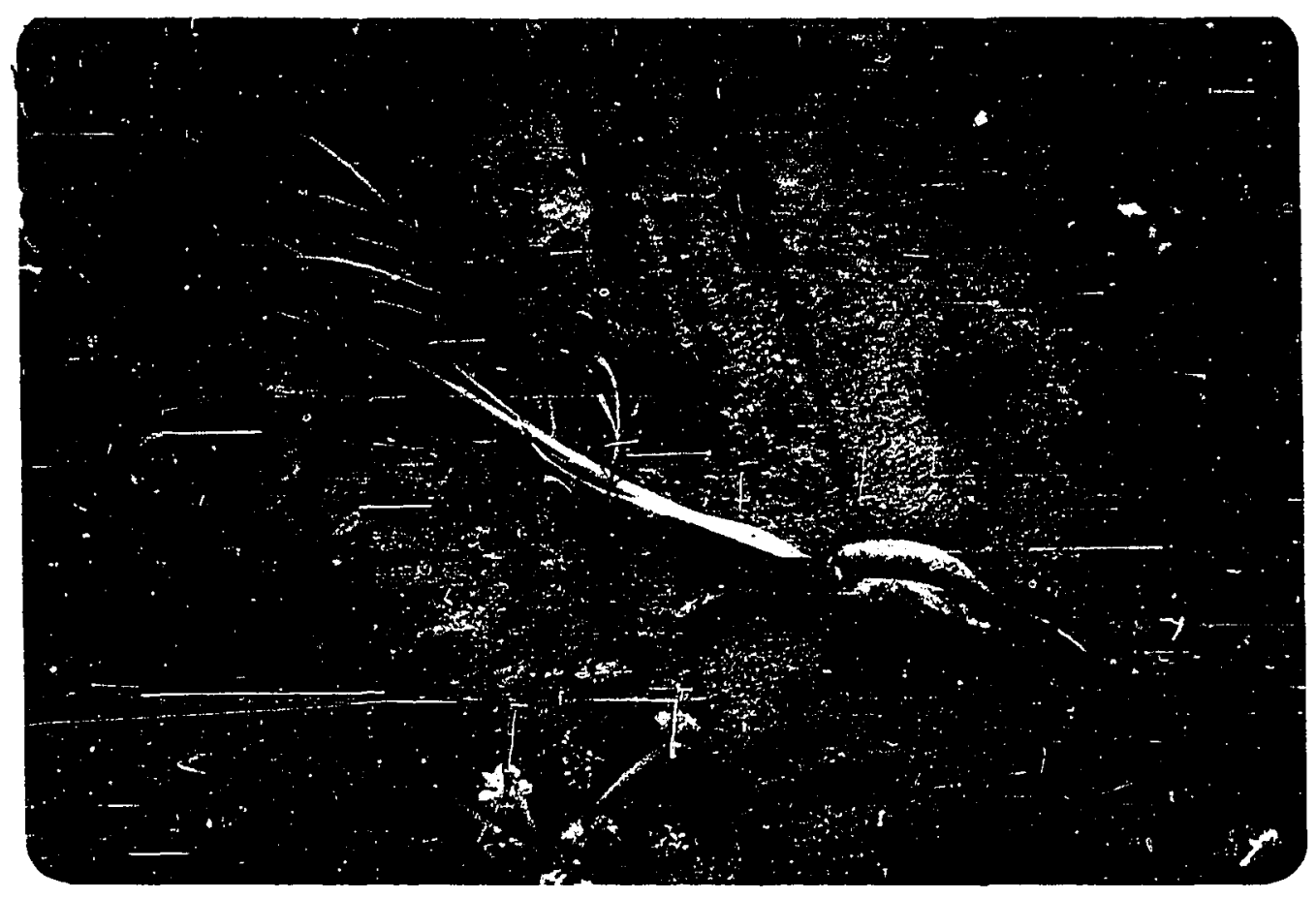

Figure 26. Pamahayapa (Perideridia oregana Wats.) wild carrot. 
May.

Habitat: $\quad$ Rocky dry open sagebrush desert areas in association with Trifolium macrocephalim, Lomatium cous and Allizm sp.

Distribution: Southeastern Oregon

Indian Use: POISONOUS! Children are warned that the leaves and roots are toxic. ${ }^{46}$

Kelly (1932:104) reported that wild iris and wild parsnip

(hakinopu) were both considered poisonous by the Surprise Valley Paiute.

Native term: Unknown

HeZianthus sp. (Compositae)

Common Name: Sunflower

Description: An annual with large yellow-headed flowers and prickly hairy stalks; blooms from June to September.

Habitat: $\quad H$. annus ranges from dry to moist open areas in valleys and foothills.

Distribution: Native to western United States (Hitchcock and Cronquist 1974:528).

Indian Use: Steward $(1941: 375)$ reported that $H$. connuus L. was utilized by the Burns Indians. ${ }^{47}$

Paku (H. bolanderi Grey) was a significant food plant for the Owens Valley Paiute (Steward 1933:243), widely distributed and was irri-

${ }^{46}$ Reportedly, "Scarface Mary" who married "Big Dick" tried to commit suicide by eating a poisonous parsnip (Del.phinizm sp.). However, her unsuccessful attempt was thwarted by a Shaman who used hot rocks and tried to suck the poison out, resulting in severely burning her cheeck (thus the scar!); she dies long ago as did her children.

${ }^{47}$ They did not acknowledge to me that it was formerly used. 
gated in some localities. Harvested in late summer, the flowers were dried in the sun, threshed and winnowed. 
CHAPTER VII

\section{AN EXPLORATION IN TAXONOMIC PRINCIPLES}

Within the last decade interest in Great Basin aboriginal taxonomy has grown, and the foremost researcher of native classification systems studies for this area has been Catherine S. Fowler (Fowler and Leland 1967; Fowler 1970). Because this exploration was done under Timited conditions, i.e., 1 imited vocabulary, available time of informants, variability of responses, and nonavailability of phonological and syntactical information on the language, Fowler's work (1967, 1970) was used as a reference point from which to begin, and this analysis is presented as a minor feature to this thesis.

I attempted to explore the basis of classification of native plants of the Harney Valley Paiute as currently recognized. T'inrough the use of informal interviewing of older tribal members, both indoors and in the field situation, I elicited vocabulary, as well as information on the uses of specific plants and upon the role and relationship of plants to their culture.

Samples of plants were collected accordingly and deposited in an herbarium in the Anthropology Department at Portland State University. I viewed mil lack of botanical background as somewhat of an advantage; I was rot able to impose any preconceived taxonomic notions on actual native categories. However, to insure that the study was conducted under controlled conditions of a scientific nature, the plants were 
carefully collected and turned over to Dr. B. E. Lippert, Biology Department; Portland State University for his determination. In addicion, I consulted with Dr. David French and Dr. Catherine S. Fowler, relying upon their judgement and expertise.

The native inhabitants have retained for the most part native terms for specific plants, and these terms ure used within an English grammatical structure. At first the native language appeared to me to be no longer in use; however, over time, fluent speakers, which include younger people as well, have spoken in my presence, and they no longer deny its use.

As with Fowler and Leland's study (1967), I found that the most inclusive terms and the least inclusive terms were easily elicited, while elusiveness existed at the intermediate levels. Formal interview techniques and the use of eliciting frames in an attempt to determine relationships and class inclusion based on the "kind-of" relationship (Conklin 1962:129; Frake 1962; Metzer and Wi7liams 1966) met with unresponsiveness and 1ittle success; and, therefore, did not seem the most appropriate approach for my purpose.

Based upon an analysis of the content of informal interviews and the application of native terms, there appears to be a major division based upon the concept of use vs. non-use. Furthermore, plants appear to be segregated on the basis of whether they are eaten or not eaten. When individuals were asked for the name of a plant for which there was no specific use, they pointed to it and replied: "That's just a flower" or "That's just grass" or "That's just growth." These findings confirm with Leland and Fowler $(1967: 383,394)$. 
Things that are eaten are always discussed first by informants, followed by things that are used, followed by things not used. According to Fowler and Leland (1967:383) things that are eaten is further subdivided into:

1. Things that grow in place

a. Those found in water

b. Those in the earth

2. Things that move.

The data supports Fowler's $(1967: 383)$ conclusions that things that grow in place, i.e., "plants that grow in the ground" are further grouped according to the part of the plant that is eaten; for example, seeds, roots, berries and greens. ${ }^{1}$

Seeds are represented by the following:

waada (Sueda depressa)

aki (Wyethia sp.)

waiya (Elymus cinerus)

tyba (Pinus ponderosa)

aca (Sisymbrium sophia)

guuha (Mantz?lia sp.)

kusiaki (Balsamorhiza hookeri Nutt.)

suunuu (Atriplex sp. [Whiting 1950:19])

Roots are represented by the following:

yampa (Perideridia bolanderi)

kyyga (Azzizım sp.)

${ }^{1}$ I found no evidence or reference to an additional category "flesh" (Fowler 1967:383). 
kanicy (Jewisia rediviva)

cuka (Lomatizm cous)

cana-cuka (also called haapi [Lomatirm canbyi])

paazigo (Camassia quamash)

winida (Fritizlaria pudica)

koogi (Calochortus sp.)

kwidapoo (Lomatizm gormanii)

Berries are represented by the following:

pokopisa (also called tooicabui [Pmunus virginiana demissa])

acapui (Ribes cereum)

pokopisa (Ribes aureum)

wiapui (Shepherdia argenta)

tokaponoma (Vaccinizm membranacerm)

Greens are represented by the following:

kyyga (Allium sp. [the tops of the plant])

wild celery (native term unknown)

The topic of things used for making things prompted a discussion

of plants such as sagebrush (cordage), willows (basketry), juniper (bows), greasewood (ear piercers), and pine (pitch).

The topic of medicines prompted a discussion of uses of plants according to whether they were smoked, drunk, chewed or applied topically as a poultice, and the associated ailments, given the following plarits as examples: sagebrush (tea), juniper (tea), yarrow (poultice), rabbitbrush (chewed), tobacco (smoked), and mint (tea).

The topic of possible poisons prompted a discussion of koogi (Zygadenus venenosus) and poison parsnip (native term unknown IDeiphinium 
sp. or Larkspur]).

The category syrbi is classified on the basis of use in manufacturing basketry, and refers simultaneously to willow (Salix sp.) and red-osier dogwood (Cornus stolonifera). According to Fowler (personal communication), syybi is an ancient Uto-Aztecan term which designates "weft" or "weaving."

The category of forest or timber (wohopi) refers to what are commonty designated as tal1 woody trees growing in the mountain environment and includes such members as fir tree (kataabi) and ponderosa pine (wohopi)..$^{2}$

The category of grass (wahaby) which includes hay, grass and reeds, distinguishes plants on the basis of physical appearance, referring to those with parallel sided leaves, growing in clumps and coming within the realm of things not used. The categories of forest and grass agree with Fowler and Leland's findings (1967:390).

Fowler (personal communication) has suggested that the semantic focus among most Northern Paiute is on the product rather than the plant; therefore, the designations are probably "food names" for the plant part which was eaten, i.e., cuka: black edible tuber dug in spring which becomes white when peeled.

Based upon an analysis of the interview content and taking into account the application of the native term, there does seem to exist a basic, but rather loose, system of classification for plants in accordance with Leland and Fowler's findings (1967; Fowler 1970). Where-

\footnotetext{
${ }^{2}$ Note: wohopi contrasts here at a different level.
} 
as modern botanical taxonomic systems, i.e., Hitchccck and Cronquist (1973) are the result of the formulation of precise rules delimiting classification at numerous levels using such criteria as genetic, anatomical, morphological, ecological, etc., data and relationships, in the folk taxonomy of the Harney Valley Paiute only a few criteria are considered and these appear, for the most part, to be obvious physical attributes or cultural traits. 
CHAPTER VIII

\section{COMPARISON WITH SURPRISE VALLEY PAIUTE AND OWENS VALLEY PAIUTE}

In the Great Basin Plateau areas of the western United States the plant life is rather restricted and in most cases adapted to arid conditions. The higher elevations produce more edible species which frequently range down into the desert valleys along stream courses. Edible seeds are by far the most common and comprise over half of the available species. The Surprise Valley Paiute and the Owens Valley Paiute were selected by me as a basis of comparison to the Harney Valley Paiute and were chosen on the basis of affinity with the Great Basin. the Uto Aztecan language group and the availability of data.

The Surprise Valley Paiute

The Surprise Valley Paiute lived aboriginally in the northeastern corner of California and adjacent parts of Oregon and Nevada. Linguistically they are affiliated with the Western Numic (Paviotso) branch of Uto-Aztecan stock. Kelly (1932) reported that formerly Surprise Valley was a meadowland, ${ }^{1}$ except for three lake playa beds. Warner Mountains with slopes of juniper - sage growth, and higher elevations with pine and fir, as well as the Valley covered with tule swamp and lakes except for sagebrush on the dry Tand, presented a varied

\footnotetext{
${ }^{1}$ Because of overgrazing the meadow has been replaced by sagebrush.
} 
environment. The Indians had continuous and extensive seasonal food resources, including seeds, roots and berries from which to select. Winter camps were composed of five or six houses while sunmer groups were smaller with two to three houses. Deer and rabbits were hunted year round with communa rabbit drives in the fal1. Depending on the season they hunted antelope, groundhogs, porcupines, squirrels, crickets, wildcat., and water fowl. Not following any set scheme, they migrated wherever the food supply seemed most promising (Kelly 1932).

\section{The Owens Valley Paiute}

The Owens Valley Paiute are the southernmost group of the Northern Paiute and linguisticaity are affiiiated with the Western Numic (Mono) branch of Uto-Aztecan stock. Bounded on the west by the Sierra Nevada and on the east by the Inyo and White Mountains, Owens Valley stretches for 75 miles, ranging 6-10 miles in width with an average elevation of 4000 feet. With Artemisia dominant in the dry lands, the valley traditionally exhibited extensive marshes and grass lands watered by the streams fed by the Sierra Nevada Mountains. The mountain ranges supported junipers, pinyons and other pines above 6000 feet.

Seasonally, fishing arid grass seed gathering was conducted in valley villages during the summer; in the fall people assembled for dancing, gambiing and communal rabbit drives; in the winter they generally assembled in the mountains in pinenut areas, returning to the valleys in spring for root digging. They hunted for deer, mountain sheep, jackrabbits and small game at all seasons, and their seasonal movements were within a fifteen to twenty mile radius from the valley 
village. According to Steward (1938:50-51), the relative abundance of resources in this area permitted the formation of larger village groups ${ }^{2}$ compared with the "kin cliques" (Fowler 1965:112) further north and east in the Great Basin.

Steward (1933) reported that 1 imited irrigation was practiced in the Owens Valley because it increased the natural yield of several wild seed plots. ${ }^{3}$ The plots chosen were based on dam and ditch building converience as well as soil drainage and seed yield, with a head irrigator assisted by other men in charge of the operation. The watered plots covered a two mile square area, and the overflow aided in the growth and subsequent harvest of wild grasses and other plants. The dam was destroyed in the fail allowing for the harvesting of the wild plants (Steward 1933:247). Steward (1930) firmly believed they were on the verge of agriculture without achieving it.

The problem of irrigation among the Owens Valley Paiute was reexamined recentiy by Lawton, WiTke, DeDecker and Mason (1976), on the basis of historical documents which may not have been accessible to Steward at the time his study was made. In 1855-1856, A. W. Von Schmidt, a surveyor under contract to the U.S. Government, mapped and recorded township, section lines, soil and terrain characteristics on plat sheets. As well, he unknowingly mapped an extensive system of irrigation channels, apparently not recognizing them for what they were. From

\footnotetext{
${ }^{2}$ Population-wise, Steward $(1933: 237)$ piaced the Owens Valley Paiute at about 1000 oir 2.5 persoris per square mile.

${ }^{3}$ Particularly crops of tupusi'i and nahavita which Steward identified as Brodiaea capitata and Eleocharis sp. respectively.
} 
this and other ethnohistorical evidence, Lawton et al (1976) concluded that ditch irrigation was far more extensive than imagined by Steward; and they were able to properly identify the primary plants irrigated by the inhabitants of Owens Valley. ${ }^{4}$ Furthermore, Lawton, et al (1976:15) suggested that this practice of irrigation "was almost certainly of indigenous origin, and that they were engaged in agriculture by definition" and, that their system of "agriculture" which they developed was unlikely to have been achieved over a brief span of time (Lawton et al 1976:39).

If we compare the gathering practices of the Harney Valley Paiute with the Owens Valley Paiute and the Surprise Valley Paiute, we find that infinite variety exists among the groups. Downs (1964:40 reported that immense variation existed within the Great Basin among all groups. Of the literally dozens of species of seeds, roots, berries and herbs that, were harvestable, only twenty were commonly gathered by all three groups and of these the species generally differed. Furthermore, the Harney Valley Paiute shared approximately $40 \%$ of the plants harvested by the Owens Valley Paiute, and approximately $60 \%$ of those harvested by the Surprise Valley Paiute. The number shared, as well as the unshared proportion that was unique to this group or that group, is a reflection of selection, variation (environmental and quantitative),

"They determined that tupusi" (Steward's Brodiaea capitata) was in fact taboose grass or yellow nut-grass (Cyperus esculentus L.) also known as chufa, earth almond, and zulu nuts (Lawton, et al 1976:34). Nahavita (Steward's Eleocharis sp.) was wild hyacinth or blue dick formerly known as Brodiaea capitata and currently classed as Dichelostemma pulchelza, also known as "grass nuts" or "nut grass" (Lawton, et al 1976:33). 
and manipulation. As indicated, the Harney Valley Paiute shared more with the Surprise Valley Paiute. It is not absolutely clear how much is the result of separate enviromments, separate traditions, or separate tastes. 


\section{CHAPTER VIX}

\section{CONCLUSIONS}

The collection of some plants has persisted into the modern period. Today a few inhabitants still collect wild plants in the same localities, using many of the same implements of their forebearers. The wooden digging stick of the past has given way to an iron counterpart or more modern implements. Modern Paiute women do their grinding on traditional milling stones with manos or pestles which are picked up from prehistoric habitation sites. They are proudly displayed in the home or garden to be used as the need arises.

Wild food plays an insignificant part in the modern Paiute diet, but the people keep the practice alive by continuing to collect those plants which are important to them, including more than seventeen edible species growing at Pine Creek. Though still a favorite, camas is no longer dug, because they are prohibited from entering private lands to dig. Berries and fruit continue to be collected, and they travel far and wide for their favorites and for a pleasurable outing.

On the other hand, due to the small yield and the great effort demanded, seed collecting faded with the introduction of whole grain flour by the white man. Curiously enough, the 76 year old woman who so eloquently revealed to me the exact location of waada, its distribution, the manner of collection, preparation and use of it, had never been to the site except as a very young child when she accompanied her grand- 
mother there. Her information was based upon oral history which passed down through generations. Only by a series of fortuitous events did she finally revisit the site in 1976, and gathered some for herself which was reduced to a small quantity of the tiny balck seed - the first to be collected by her in al1 her 76 years.

Various other plants are still utilized in a variety of ways. Willow is still collected on the banks of the Silvies River for use in manufacturing cradle boards by several women, while the use of basketry declined in the 20th Century to the point where vessels as such are rarely manufactured. Sagebrush tea is used to relieve cold and flu symptoms when all else fails. Yarrow has reportedly been used recently to heal sores, and mint tea is still enjoyed.

Methods of preparation have been influenced by modern technology. Yampa is frequently flash frozen today instead of dried in order to preserve its freshness, as are other roots. Wild onions are sometimes pickled in vinegar. Bitterroot is preferred as a desert with milk and sugar. Sugar has been added to seed gruel and to fruits in recent times. Basketry and hot stones have given way to wood and electric ranges, and to skillets and electric appliances in cooking.

Today trading food and buckskin with other Indian groups is sti11 a practice, but the exchange is measured in terms of doliars. Bitterroot and cuka are still sought after from these Indians by people in Warm Springs, Portiand, McDermitt, and from as far away as Yakima, Washington. Those who request to trade are regarded as "too lazy to dig their own." One woman has been importing buckberries ${ }^{1}$ from northern

\footnotetext{
${ }^{1}$ According to Catherine Fowler (personal comunication) this
} 
Nevada for years. In addition, huckleberries and buckskin are also regarded as trade items.

Wild foods don't contribute much to the diet of these people. However, despite the fact that the practice of collecting native plants for food and other uses seems to be vanishing, and despite the fact that there have been gaps in the transmission and in the use of information relating to wild foods - 76 year old gaps, the knowledge still remains. All because a few people still cling to their old ways and keep the practice alive because the process of gathering and preserving makes up a rituai which to them is both fun and usefur.

Although Wissler (1922) and Underhill (1953) described the Ereat Basin as an area with meager resources, based upon empirical observation and an examination, I suggest that food resources for the Harney Valley Paiute were varied, including a wide variety of plant resources as well as numerous species of fish, birds, smal1 and larger game animals, al1 available for the taking. Given the fact that all cultures make choices from the wide variety of plants available, these people are no exception. They tended to make choices and were selective in their collection and utilization of certain plants and animals, taking into account personal preference, need, taste, cleanliness, size, ripeness, difficulty in collecting and work involved, manner of preservation, avaitability arius seasonality, the presence of other people, as well as the necessity of choosing the proper materials at the best time for their specific purpose. Viewing the Great Basin from the standpoint of re-

species is quite likely Shepherdia argenta which grows in Yerrington, Nevada. 
source poverty (Wisster 1922; Underhi11 1953) is an idea refuted by Kelly (1932); Steward (1933, 1938); Stewart (1941); and Fowler (1966). The ecological variations and the resulting adaptations represented by such groups as the Surprise Vailley Paiute, the Owens Valley Paiute and the Harney Valley Paiute refute the notion of resource poverty.

Furthermore, the conditions at Pine Creek Root Camp, including the localized abundance of cuka, yampa and bitterroot, as well as the salmon fishery on the Malheur River, favored the congregation of large groups of people for at least a month to six week period in the spring of each year and apparently led to the development of regular trade among the inhabitants of the Northern Great Basin, including the Harney Vailey Paiute, the Bannock, the Shoshoni of Idaho, the Surprise Valley Paiute, and the Warm Springs Indians, and extended to include the Umatilla Indians of the southern Plateau, and the "Columbia River Indians." I believe this was not unlike the Big Camas Prairie near Fairfield, Idaho, which developed into a significant trading center bringing together such native populations as the Bannock, the Shoshoni of Idaho, northern Utah and Wyoming (Maury 1902:226 in Murphy and Murphy 1960:320; Steward 1938:191-192, 167, 200, 203, 205, 217; Li1 jeblad 1957:70, 106) and included the Nez Perce Indians of the southern Plateau (Steward 1938:191; Murphy and Murphy 1960:321).

This is an area where native practices and traditional lore tend to survive. The degree to which they do is represented by a taxonomy, and the kinds of conditions through which traditional lore has survived for these people include displacement, acculturation and education. A 1 imited amount of social interaction exists in Burns between the native 
community and the greater white population, and what interaction there is seems to be governed largely by economic necessity. The reasons for the disjunction of the two groups, I believe, are related to the fact that "the Indians lost the war," and the fact that the dispensation of claims to the Malheur Indian Reservation resulted in an insignificant final payment and years of almost hopeless waiting which have been a source of frustration and bitterness among these Indians.

Following the trend of other American Indian groups, the Burns Indians have gained legal tribal status, tribal land holdings, representative attendance at national Indian meetings, the participation of members in BIA relocation projects, the construction of a new community center and more than nine new homes within the past year, the implementation of new programs including alcoholic rehabilitation, and are attempting training programs and some form of light industry, all in an effort to actively seek ways of succeeding in two cultures with widely differing values simultaneously. 


\section{APPENDIX A}

\section{NOTE ON ORTHOGRAPHY}

Transcription of native terms is broadly phonetic and similar to that presented by Fowler and Leland (1967), as follows:

Vowe1s:

$$
\begin{aligned}
& \text { a - as in English "father" } \\
& i \text { - as in "beat" } \\
& 0-\text { as in "boat" } \\
& u \text { - as in "book" } \\
& y \text { - as in "just" }
\end{aligned}
$$

Consonants:

$$
\begin{aligned}
& c \text { - is the symbol for "ts" } \\
& \eta \text { - as in "ring" }
\end{aligned}
$$

Pronunciation appears to be subject to much free variation, especially in the treatment of terminal and whispered syllables. For this reason, I have not indicated accent and final unstressed vowels. 
APPENDIX B

\section{DICTIONARY OF PLANT NAMES}

\section{Common Name}

Aspen

Biscuit root

Biscuit root

Biscuit root

Biscuit root

Bitterroot

Blackberry/Black haw

Blazing Star/Stickleaf

Blue or black huckleberry/ Blueberry
HVP: guuha

SVP: guha

OVP: kuha

Native Term

HVP: cinabi

HVP: cana-cuka/haapi

Sur: tsana-tsuga/hapi

HVP: cuka

SVP: tsuga

HVP: haapi

SVP: hunibui

HVP: kwidapoo

HVP: kanicy

SVP: kanutcu

HVP: kwinaapisa

SVP: kwinupC

HVP: tokabonoma

\section{Botanical Name}

Populus tremuloides Michx.

Lomatium canbyi

Lomatium cous

Lomatium macrocarpum

Lomatium gormanii

Lewisia rediviva

Unknown

Crataegus douglasii

Lind1.

Mentzelia Zaevicaulis Doug 1 .

Vaccinium membranaceum
General Use

Bark for working hides

Roots eaten

Roots eaten

Roots eaten

Roots eaten

Roots eaten

Berries eaten

Seeds eaten

Berries eaten 
Common Name

Buckberry/Silver buffalo berry

Camas/Blue camas

Carrot, wild

Carrot, Indian

Epos

Cat-tail

Chokecherry

Clover, big-headed

Currant, golden

Currant, squaw
Native Term

HVP: wiapui

SVP: wiyupui

OVP: wiyup $i$

HVP: paazigo

SVP: pasigo/tapakogi

HVP: yapa/yampa/payapa/ suiyapa

pamahayapa

SVP: yapa

payapa

HVP: toiby

SVP: toibu

OVP: toiva

HVP: tooisabui/pokopisa

SVP: doicabui

OVP: pogobic

HVP: poziidapy

HVP: pokopisa

SVP: bokopc

OVP: pogobic

HVP: acapui

SVP: atsapui

\section{Botanical Name}

Sheperdia sp.

Sheperdia argenta

Eleagnus argentae

Camassia qucmash

Perideridia bolanderi

Perideridia oregana

$$
\text { Wats. }
$$

Carum oreganum Wats.

Sirm cicutaefolium

Typha Zatifolia L.

Prunus virginiana

(Unidentified)

Trifolium macrocephalum

Ribes aureum Pursh

(Unidentified)

Ribes cereum

\section{General Use}

Berries eaten

Root eaten

Root eaten

Seed, shoots and root eaten/building material

Berries eaten

Nectar as sweetener

Berries eaten

Berries eaten 
Common Name

Death camas

Delphinium/wild parsnip

Dogbane/Indian hemp

Dogwood, Red osier

Juniper

Mariposa $1 \mathrm{ily} /$ Sego $1 i 1 y$

Mint, wild or field mint

Mouta in mahogany

Onion, witd

\section{Native Term}

HVP: koogi

HVP: Unknown

SVP: hakinopu

HVP: wihowi

HVP: syybi

HVP: waapi

$\begin{array}{ll}\text { HVP: } & \text { koogi } \\ \text { SVP: } & \text { kogi } \\ \text { OVP: } & \text { sigo }\end{array}$

HVP: pakwana

OVP: kwananuvuva/waiyanuva

HVP: tuupi

SVP: tupi

HVP: kyyga

sii

SVP: guka

panizi

mua

bidisi

OVP: paiduci
Botanical Name

Zygadenus venenosus

DeIphinium sp.

Apocynum cannabinum

Comus stolonifera

Juniperus occidentalis

Calochortus macrocarpus Dougl.

Mentha arvensis

Cercocarpus ledifolius

AlZium acuminatum,

A. tolmiei Baker

A. madidum Wats.

A. acrominatum Hook

A. platycaule Wats.

A. pleianthum Wats.

A. bisceptrum Wats.

Unidentified
General Use

\section{POISONOUS}

POISONOUS

Bark as cordage

Basketry

Berries eaten and used medicinally. wood for fuel building material

Root eaten

Leaves and stems as tea

Digging sticks

Roots, leaves and seeds eaten 


\section{Common Name}

Pentstemion

Pigi sed

Pine

Pinyon pine

Plum, Pacific wild

Rabbit brush

Rose hips

Sagebrush

Salt brush
Native Term

HVP: namogot

HVP: wata/iape

SVP: wata

OVP: wata

HVP: tyba

HVP: tyba

SVP: tuba

OVP: tuva

HVP : tuyu

SVP: tuyu

HVP: sigupi

HVP: siabi

SVP: tsiabi

OVP: tsiava

HVP: sawabi

SVP: sawa

OVP: sawava/sawavi/ sawavuya/sawapi

HVP: suunuu

OVP: sunuva
Botanical Name

Pentstemon sp.

Chenopodium album L.

Pinus ponderosa

Pinus monophyzza

Prunus subcordata Benth.

Chrysothormus

nauseosus

Rosa sp.

Rosa pisocarpa Gray

Artemisia tridentata Nutt.

Atriplex sp.
General Use

Leaves medicinally

Seeds eaten

Seeds eaten; pitch as waterproof;

cambium as

sweetener

Seeds eaten

Fruit eaten

Sap chewed

Hips eaten and as beads

Bark for cordage and weaving; wood for fuel; leaves medicinally

Seeds eaten 
Common Name

\begin{tabular}{|c|c|c|}
\hline Seepweed & $\begin{array}{l}\text { HVP: } \\
\text { SVP: }\end{array}$ & $\begin{array}{l}\text { waada } \\
\text { wada }\end{array}$ \\
\hline Sunflower & $\begin{array}{l}\text { HVP: } \\
\text { SVP: } \\
\text { OVP: }\end{array}$ & $\begin{array}{l}\text { Unknown } \\
\text { pahu } \\
\text { paku }\end{array}$ \\
\hline $\begin{array}{l}\text { Sunflower/Rock balsam- } \\
\text { root }\end{array}$ & $\begin{array}{l}\text { HVP: } \\
\text { SVP: }\end{array}$ & $\begin{array}{l}\text { kusiaki } \\
\text { bikwaida }\end{array}$ \\
\hline Tansy-mustard & $\begin{array}{l}\text { HVP: } \\
\text { SVP: } \\
\text { OVP: }\end{array}$ & $\begin{array}{l}\text { aca } \\
\text { atsa } \\
\text { atsa }\end{array}$ \\
\hline Tobacco & $\begin{array}{l}\text { HVP: } \\
\text { SVP: } \\
\text { OVP: }\end{array}$ & $\begin{array}{l}\text { puihibamo } \\
\text { puhipamo } \\
\text { pamupipahmu/pahumbi }\end{array}$ \\
\hline Tule & $\begin{array}{l}\text { HVP: } \\
\text { SVP: }\end{array}$ & $\begin{array}{l}\text { saiby } \\
\text { saibu }\end{array}$ \\
\hline Willow & HVP: & syybi \\
\hline Wyethia/Mule's Ears & $\begin{array}{l}\text { HVP: } \\
\text { SVP: } \\
\text { OVP: }\end{array}$ & $\begin{array}{l}\text { aki } \\
\text { agu } \\
\text { aku }\end{array}$ \\
\hline
\end{tabular}

Botanical Name

Genera? Use

suaeda intermedia suaeda depressa var. erecta Wats.

Helianthus sp.

H. annuus L.

H. bolanderi

Balsamorhiza hookeri Seeds and roots Nutt.

$B$. terebinthacea Nutt.

Descurainia sophia L. Seeds eaten

Radicula sp.

Nicotiana attenuata Smoked and used Torr.

Scirpus validus Vaht

Salix sp.

Wyethia sp.

W. molzis Gray

W. ovata T. \& G. eaten

Seeds eaten

Seeds eaten

Shoots and roots eaten; stems for cordage, basketry

\section{Basketry}

Stems and seeds eaten; leaves medicinally 
Common Name

Yarrow

Yellow bell

\section{Native Term}

HVP: wodaa kwasiba

HVP: winida
Botanical Name

Achillea nillefolium

Fritillaria pudica
General Use

Leaves medicina $77 y$

Roots eaten 


\section{BIBLIOGRAPHY}

Key to Bibliographic Symbols

AA - American Anthropologist
BAE-B - Bureau of American Ethnology Bulletin
BAE-AR - Bureau of American Ethnology Annual Report
UCP-AAE - University of California Publications in American
UCP-AR - Urchaeology and Ethnology
UCP-L - University of California Eublications, Anthropological
- University of California Publications in Linguistics

Adovasio, J. M., R. Andrews and R. Carlis?e

1976 The Evolution of Basketry Manufacture in the Northern Great Basin. Tebiwa 18(2):1-8.

Aikens, C. Metvin

1970 Hogup Dave. University of Utah Anthropological Paper 93.

Aikens, C. Melvin, David L. Cole, and Robert Stuckenrath

n.d. Excavations at Dirty Shame Rockshelter, Southeastern Oregon. Tebiwa. (In press, ms. 1976).

Antevs, Ernst

1955 Geologic-Climatic Dating in the West. AA 20(4):317-35.

Bailey, Vernon

1936 Mamma7s and Life Zones of Oregon. North American Fauna No. 55. Washington: U.S. Dept. of Agriculture. Bureau of Biological Survey.

Baldwin, Ewart M.

1964 Geol ogy of Oregon. Ed. 2, 165 p., i17us. Eugene: Univ. Oreg. Coop. Bookstore.

Baumhoff, M. A., and R. F. Heizer

1965 Postglacial Climate and Archaeology in the Desert West. In The Quaternary of the United States. H. E. Wright, Jr. and D. G. Frey, eds. Pp. 698-708. Princeton: Princeton University Press. 
Bedwe11, S. F., and L. S. Cressman

1971 Fort Rock Report: Prehistory and Environment of the Pluvial Fort Rock Lake Area of Southcentral Oregon. University of Oregon Anthropological Papers 1:1-25.

Birins, Archie

1967 Peter Skene Ogden: Fur Trader (1st ed.). Portland: Binfords and Mort., Publishing.

Boyd, Robert T.

1975 "Another Look at the 'Fever and Ague' of Western Oregon." Ethnohistory. Vol. 22, No. 2, Spring '75, pp. 125-154.

Burns Chamber of Commerce Correspondence.

Cline, Gloria G.

1963 Exploring the Great Basin. Norman: University of Oklahoma Press.

Cook, S. F,

1955 Epidemic of 1830-33 in California and Oregon UCP-AAE $43(3): 303-326$.

Davis, Wilber A.

1966 Theoretical Problems in Western Prehistory. In The Current Status of Anthropological Research in the Great Basin: 1964. Warren L. d'Azevedo, et al. (Eds.), pp. 147-65. Desert Research Institute, Social Sciences and Humanities Publications, No. 1, Reno.

d'Azevedo, Warren L., et al (Eds.)

1966 The Current Status of Anthropological Research in the Great Basin: 1964. Desert Research Institute, Social Sciences and Humanities Publications, No. 1.

Downs, James F.

1966 The Significance of Environmental Manipulation in Great Bas in Cultural Development. In "The Current Status of Anthropological Research in the Great Basin: 1964, "Warren L. d'Azevedo, et al., (Eds.), pp. 39-56. Desert Research Institute, Social Sciences and Humanities Publications, No. 1. Reno.

Euler, Robert C.

1966 Comments on Tribal Distribution. In "The Current Status of Anthropological Research in the Great Basin: 1964, "Warren L. d'Azevedo, et al., (Eds.), pp. 309-14. Desert Research Institute, Social Sciences and Humanities Publications, No. 1. Reno. 
Extension Circular 809

1972 Nutritive Values of Native Foods of Warm Springs Indians. Extension Service, Oregon State University, July, 1972. Corval?is.

Fenneman, Nevin M.

1931 Physiography of Western United States. 534 p., illus. New York and London: McGraw-Hill Book Co.

Fowler, Catherine S. and Joy Leland

1967 Some Northern Paiute Native Categories. Ethnology, Vol. 6 , No. 4, pp. 381-404. Pittsburgh.

Fowler, Catherine

1970 Some Notes on Comparative Numic Ethnobiology. Reprinted from Great Basin Anthropological Conference, 1970 Selected Papers, C. Melvin Aikens, ed., University of Oregon Anthronological Papers No. 1, 1971.

Fowter, Donald D.

1965 Cultural Ecology and Culture History of the Eastern Shoshoni Indians. Unpublished Doctoral Dissertation, University of Pittsburgh, $201 \mathrm{pp}$.

Franklin, Jerry F. and C. T. Dyrness

1973 Natural Vegetation of Oregon and Washington, USDA Forest Service General Technical Report PNW-8, Portland, Oregon.

Fremont, John Charles

1887 Memoirs of my Life. Vo1. 1. Chicago, Beford, Clarke.

Haines, F.

1938 The Nortinward Spread of Horses Among the Flains Indians. AA 40:429-37.

Harney County Historical Society Correspondence.

Heider, K. G.

1967 Archaeological Assumptions and Ethnographic Facts: A Cautionary Tale from New Guinea. Southwestern Journal of Anthropology 23:52-64.

Heizer, Robert F.

1956 Recent Cave Explorations in the Lower Humboldt Valley. University of California Archaeological Survey Report 33: 50-57. 
Heizer, Robert F., T. R. Hester and M. P. Nichols (eds.)

1972 Notes on Northern Paiute Ethnography: Kroeber and Marsden Records. Archaeological Research Facility, Dept. of Anth., U. of Calif., Berkeley.

Hitchcock, C. Lec and Arthur Cronquist

1973 Flora of the Pacific Northwest. Seattle: University of Washington Press.

Hopkins, Sarah Winnelnucca

1883 Life Among the Paiutes: Their Wrongs and Claims. New York: G. P. Putnam's Sons.

Jennings: Jesse $D$.

1957 Danger Cave. University of Utah Anthropological Papers 27.

Jennings, Jesse $D$.

1964 The Desert West. In Prenistoric Man in the New World, Jesse D. Jennings and Edward Norbeck (eds.), pp. 149-74. Chicago: University of Chicago Press.

Kelly, Isabel T.

1932 Ethnography of the Surprise Valley Paiute. UCP-AAE 31(3): 67-210.

Kelly, Isabel T.

1938 Northern Paiute Tales. Journal of American Folk Lore.

Kroeber, A. L.

1907 Shoshonean Dialects of California. UCP-AAE 4:65-165.

Lamb, Sydney

1958 Linguistic Prehistory in the Great Basin. International Journal of American inglistics 29:95-100.

Lawton, Harry W. , et az.

1976 Agriculture Among the Paiute of Owens Valley, The Journal of California Anthropology, Vol. 3, No. 1, pp. 13-50. Malki Museum, INc., Morongo Indian Reservation, Banning, California.

Levi-Strauss, Claude

1966 The Future of Anthropology. New York Review of Books, Vol. VII, July 28, p. 6.

Lewis, M.

1814 The Lewis and Clark Expedition. 3 Vols. Philadelphia: Bradford and Inskeep. (facsimile ed. 1961, Philadelphià: J.P. Lippincott.) 
Lewis, Meriwether

1959 Original Journals of the Lewis and Clark Expedition, 18041806. Reuben Gold Thwaites (ed.). New York, Antiquarian Press.

Liljeblad, Sven

1957 Indian Peoples in Idaho. Unpublished MS, Idaho State College, Pocatello. Mimeo.

Loud, Llewel Tyn L. and M. R. Harrington

1929 Lovelock Cave. UCP-AAE.

Mahar, James $M$.

1954 Ethnobotany of the Oregon Pajutes of the Warm Springs Indian Reservation. Unpublished Bachelor of Arts Thesis, Reed College, Portland.

Marsden, W. L.

n.d. Unpublished field notes of Burns Northern Paiute Indians in Southeastern Oregon. (In possession of Catherine S. Fowler.)

Metzgar, Duane and Gerald Williams

1966 Some Procedures and Results in the Study of Native Categories: Tzeital "Firewood," AA 68(2):389-407. Menasha.

Miller, Wick R.

1964 The Shoshonean Languages of Uto-Aztecan. In "Studies in Californian Linguistics," Willianı Bright, (ed.), UCP-L, 34: 145-8.

Mooney, James

1896 The Ghost-Dance Religion and the Sioux Outbreak of 1890. BAE-AR 14(2):641-1110. Washington.

Murphey, Edith Van Alien

1959 Indian Uses of Native Plants. Mendocino County Historical Society, Ft. Bragg.

Murphy, Robert F. and Yolanda Murphy

1960 Shoshone-Bannock Subsistence and Society. UCP-AR 16(7):293-338, Berkeley.

Nickerson, Gifford S.

1966 Some Data on Plains and Great Basin Uses of Certain Native Plants. Tebiwa 9:145-151.

Secoy, F. R.

1953 Changing Military Patterns on the Great Plains. American Ethnological Society Monographs No. 25. 
Steward, Julian $H$.

1930 Irrigation Without Agriculture. Michigani Academy of Science, Arts and Letters, Papers 12:149-56.

Steward, Ju? ian $\mathrm{H}$.

1933 Ethnography of the Owens Valley Paiute. UCP-AAE 33(3): 233-350.

Steward, Julian H.

1938 Basin-Plateau Aboriginal Sociopolitical Groups. BAE-B, No. 120.

Steward, Julian H.

1955 Theory of Culture Change. University of I11inois Press, Urbana.

Stewart, Omer $C$.

1941 Culture Element Distributions: XIV. Northern Paiute. UCP-AR $4(3): 361-446$.

Stewart, Omer $C$.

1966 Tribal Distributions and Boundaries in the Great Basin. In "The Current Status of Anthropological Research in the Great Basin: 1964," Warren L. d'Azevedo, et al., (Eds.), pp. 167-237. Desert Research Institute, Social Sciences and Humanities Publications, No. 1. Reno.

Strong, Emory

1969 Stone Age in the Great Basin. Portland: Binfords and Mort.

Swanson, E. H.

1966 The Geographic Foundations of the Desert Culture. In The Current Status of Anthropologica $i$ Research in the Great Basin: 1964. W. L d'Azevedo, et al., eds. Pp. 137-46. Desert Re earch Institute Publications in the Social Sciences and Humanities, No. 1.

Swanson, Earl H., Jr. and Guy Muto

1975 Recent Environmental Changes in the Northern Great Basin. Tebiwa 18(1):49-57.

Toepel, Kathryn Anne and Stephen Dow Beckham

1978 Cultural Resource Overview of the Brothers Els Area, Prineville District, Oregon. U. S. Bureau of Land Management. Submi tted by Don E. Uumond. U. of Oregon, Eugene. U.S. Dept. of Interior.

Underhiii, Ruth M.

1953 Red Man's America. Chicago: University of Chicago Press. 
USDA Forest Service

1973 Natural Vegetation of Oregon and Washington, U. S. Dept. Agric. Gen. Tech. Report PNW-8. 417 p., illus.

U. S. Documents, Bureau of Indian Affairs

1965 American Indians and the Federal Government.

U. S. Document No. 194, Vol. 5, Laws, 76th Congress, Session 3, Johnson 0'Malley Acts pi. 364-469 Burns Subsistence Homesteads, Harney Counzy Oregon, February 1, 1937.

U. S. Documents 452, Statutes, Executive Orders, Proclamations and Statistics of Tribes, V01. 1.

U. S. Document HR 622 (1941) 1465 (1963) Public Law 88-464 August 20,1964 .

U. S. Documents, Senate Document, Vo1. 35, 57th Congress, Session 1, Indian Affairs, Laws and Treaties, Vol. II, Edited by C. J. Kappler, Government Printing Office, 1903.

U. S. Document Senate Hearing, Indian Affairs Committee, November 6-10, $193 \hat{b}$.

U. S. Government documents relative to the former Matheur Reservation, noted as Malheur Correspendence, Photostats in the Oregon Collection, University of Oregon Library.

U. S. Weather Bureau

1960 Climates of the States, Oregori. Climatography of the United States 60-35, 20 p., illus.

U. S. Weather Bureau

1965 Climatic Summary of the U. S. Supplement for '56 - ' 60 ,

Oregon. Climatography of the U. S. 36-31, 96 p. illus.

Wheat, Margaret M.

1967 Survival Arts of the Primitive Paiutes. Reno: University of lievada Press.

Whiting, Beatrice B.

1950 Paiute Sorcery. Viking Fund Publications in Anthropology, No. $15 . \mathrm{Pp} .110$.

Whiting, Beatrice

1938 Tribal Distribution in Oregon. Harney Valley Paiute. AA 40:402-405.

Wissler, Clark

1922 The American Indian. New York: Oxford University Press. 